(1)

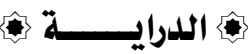

\title{
دلالة المصطلحات الخاصة بين النقاد \\ في تجريج الرواة \\ (دراسة وتحليل)
}

\author{
الدكتــــور \\ عيسى محمد عيسى شُحاته
}

أستاذ الحخيث وعلوهه المساعت بجاهحة الأزهر 
(Y)

دلالة المصطلحات الخاصة بين النقاد في تبريح الرواة (دراسة وتحليل) 
(r)

\section{بسم اللّه الرحمن الرحيم}

\section{(ملفص البمث )}

ـ هذا البحث يتناول مسألة مهمة مـن مسائل علم جـرح الرواة، وهي دلالة المصطلحات الخاصة عند الأئمة النقاد، إذ يعرض لبيان المقصود مـن دلالة اللفظ ، واستخدام المحدثين لكلمة المصطلحات الخاصة، ثم طرق معرفة

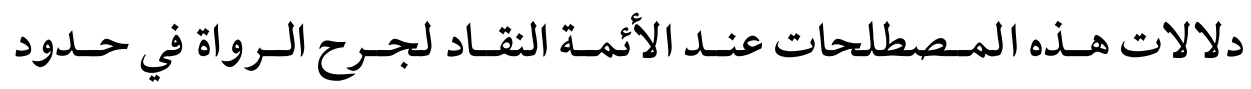

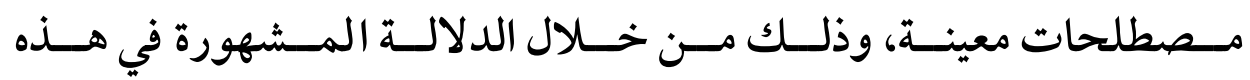
المصطلحات، ثم الدلالة الخاصة فيها أيضاً عند النقـاد، مـع دراسـة الأمثلة التوضـيحية في الجـانبين مـن كتـب الـتر اجم عـلى بعـضـ الـرواة، وهـــهـ

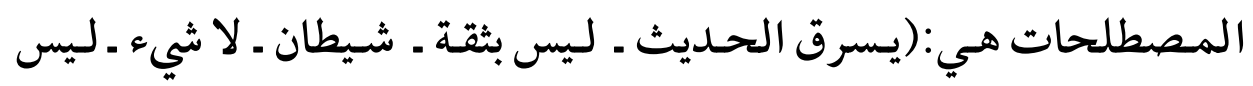
بمشهور، كذاب). ـ الكلمات الاقتتاحية:(دلالة ـ مصطلحات ـ النقاد ـ تجريح). 


\section{(ABSTRACT)}

This research deals with an important issue of the knowledge of the narrator's wound, in relation to the special terminology of the imams. It presents the meaning of meaning, the use of the terminologists for the term special terms, and the ways of knowing the meanings of these terms among the imams in certain terms, Which is well known in these terms, and its special significance also in the critics, with the illustrative examples in the janabin of the books of translations on some narrators, and these terms are: (steals the talk not with the confidence of Satan is nothing not famous). 


\section{ســـاللهالرحن الرحيـم}

\section{الاقدهمة}

الحمـــلله رب العـالمين، وأشـهـد أن لا إلـه إلا الله ولي الـصالحين، شـهادة

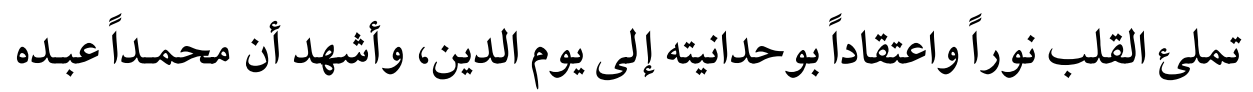

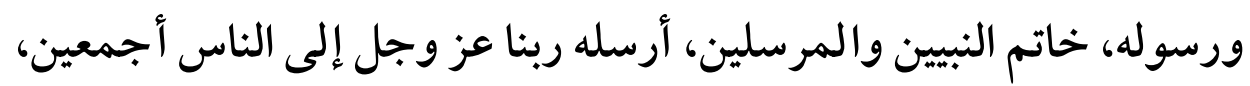

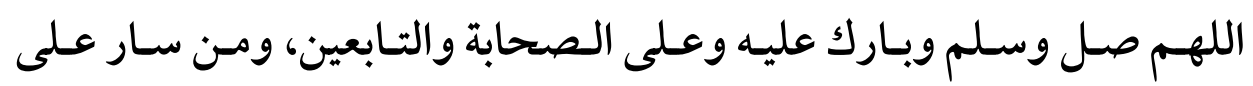
نهجهم واتبع سنة نبيهم إلى يوم الدين. وبعد: السنة المطهرة هي المصدر الثاني للتشريع بعـد كتـاب الله تعـالى، وهـذا أمر أجمع عليه علماء الأمة قديمًا وحديثًا، لم يخالف في ذلك إلا من لا حظّ لـ له

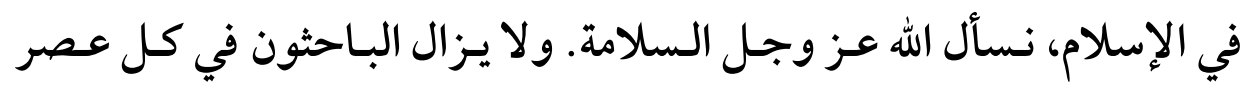

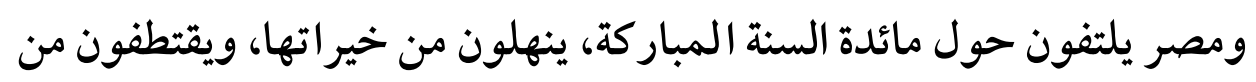

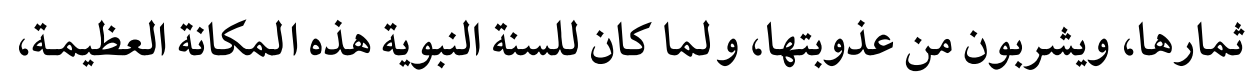
عرف السلف الصالح للسنة قـدرها، فرعوهـا حتق رعايتها، وحفظوهـا في ومان

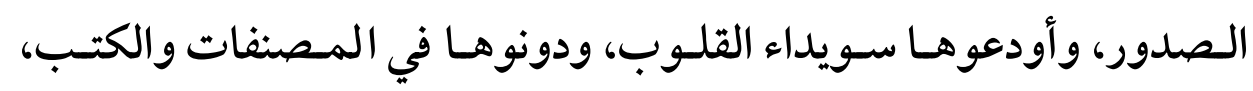
وقعدوا لها القواعد التي يستطيعون بها نقد المرويات والرواة. ومـن أبـرز مـا

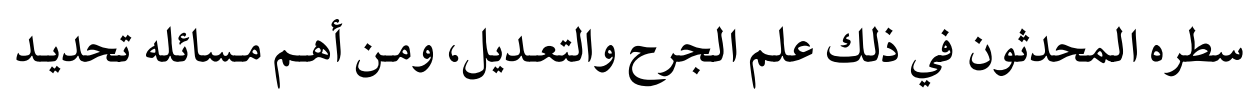
المر اد من دلالة المصطلحات الخاصة لدى بعض الأئمة النقاد، وهذه قضية مهمـة في الأوسـاط العلمية، وتعـد المصطلحات الخاصـة في بـاب الجـرح والتي تداو لها أعلام المحدثين في أقوالهم ومصنفاتهم من أبرز القواعـد في 
( دلالة المصطلحات الخاصة بين النقاد في تجريح الرواة (دراسة وتحليل)

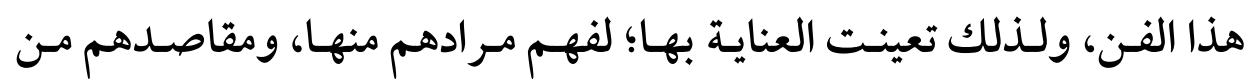
استخدامها. ثم إن الوقوف على مصطلحات كل إمام من أئمة الحـديث خاصـة في ألفـاظ

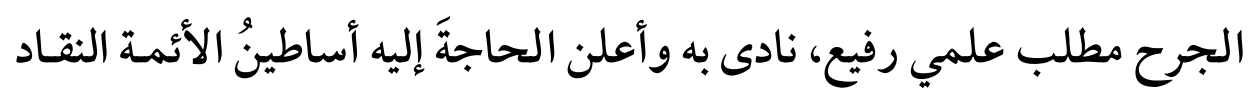

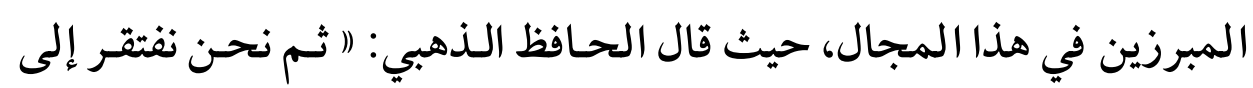
تحديد عبارات الجرح والتعديل، وما بين ذلك من العبـارات المتجاذبـة، ثم

أهم من ذلك الإمام الجهبذ، واصطلاحه، ومقاصده، بعبار اته الكثيرة ) (1).

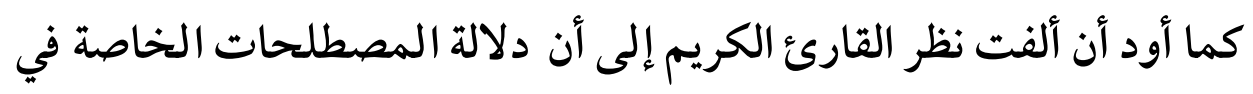

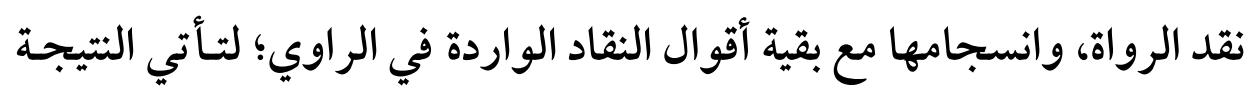

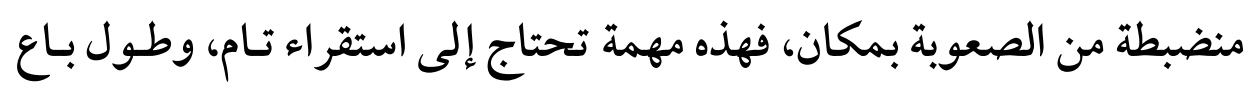
في العلم، واطلاع واسع، وبالنسبة لي فدون ذلك خرط القتاد !!

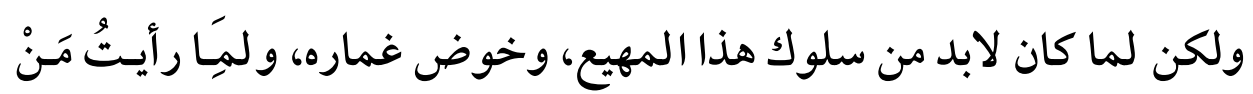

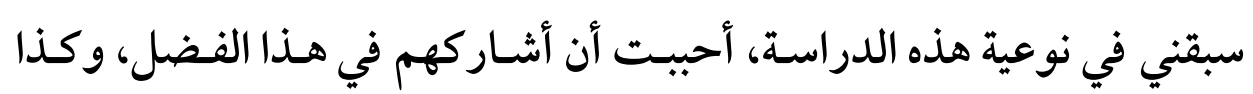
بعد مشاورة أهل العلم من أساتذتي المتخصصين، وقع اختياري على دراسة دلالة هذه المصطلحات الخاصة في باب جرح الرواة. ـ مشكلة البحث، تكمن مشكلة هذا البحث في الاستفسارات التالية:

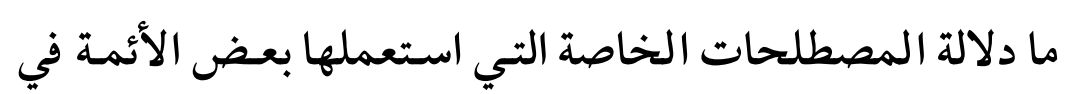

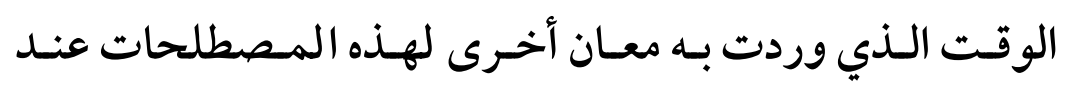

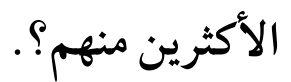

$$
\begin{aligned}
& \text { (1) الموقظة في علم مصطلح الحديث. للذهبي (ص: Y ). }
\end{aligned}
$$


(V)

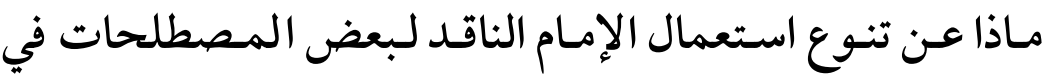
التجريح بأكثر من معنى، مما خالف فيه العموم مـن الأئمسة النقاد المحدثين؟.

هل معرفة مر اد الناقـد مـن كلامـه في الـراوي ينطبق مـع غيره في

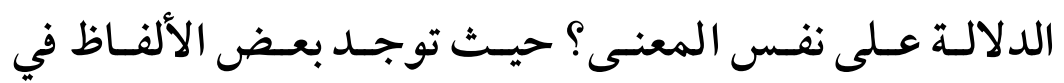

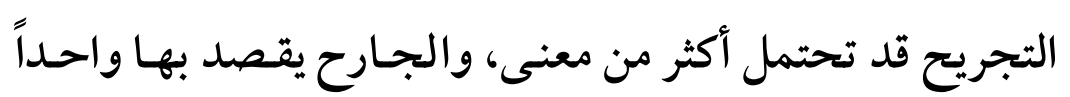

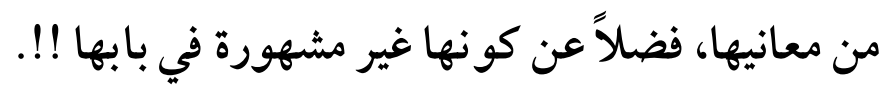
ـ أهداف الدراسة. تهاف دراستي لهذا البحث تحقيق بعض الفوائد، ومن أبرزها ما يلي:

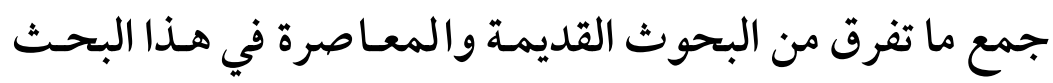

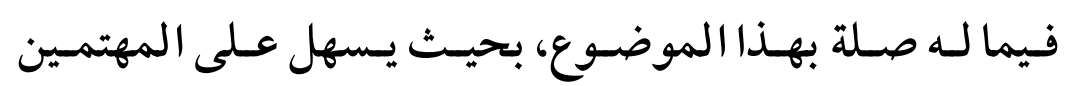
الوقوف عليه.

الوقوف على ألفاظ الجرح التي خالف بها بعض الأئمة النقاد في

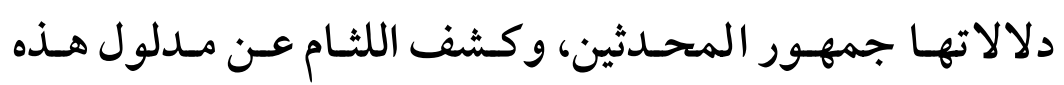
المصطلحات.

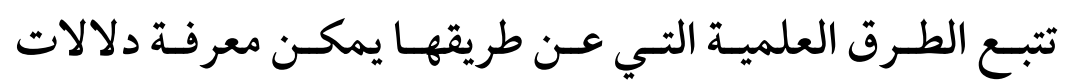
المصطلحات الخاصة للأئمة النقادة في الرواة. إضـافة جديـد لنوعيـة هـــه الدراسـة لمـن سـبقوني مـن البـاحثين المعاصرين في هذا الفرع من فروع ألفاظ التجريح. 
(A)

لقد تعددت البحوث في علم الجـرح والتعـديل بصفة عامة مـن المشتخلين

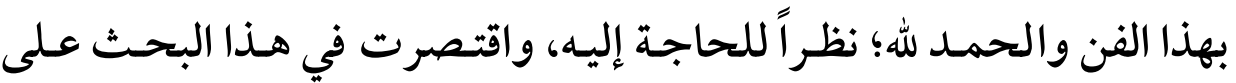
دراسة دلالة المصطلحات الخاصة في تجريح الرواة عند النقـاد مـن خـلال عدة مطالب، حيث تناولت مصطلحات الجرح لألفاظ معينة، وهي: (يسرق الحـديث ـ لـيس بثقة ـ شـيطان ـ لاشيء ـ لـيس بمـشهور، كذاب)، وكـان اختياري لهذه المصطلحات فقط دون غيرها لأسباب: تحقيق المقصد من دراسة الدلالة لهذه المصطلحات خاصـة في التجريح؛ لإخراج هذا البحث. الدراسة لدلالة جميع المصطلحات الخاصـة لجرح الرواة عند

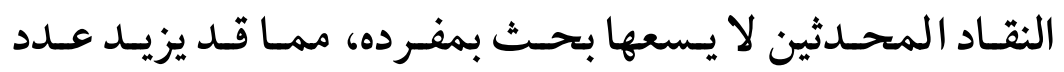
صفحاته، ويحول دون نشره في الدوريات العلمية المحكمة.

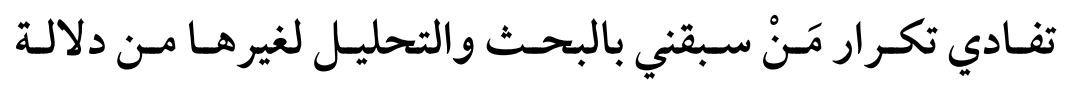

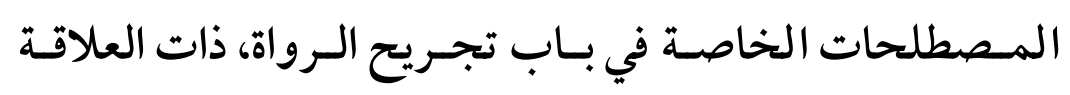
بنوعية هذه الدراسة.

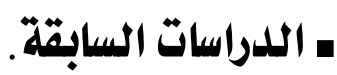

لا شـك أن بـاب الجـرح والتعــيل مـن الأبـواب المهمـة في علـم أصـول

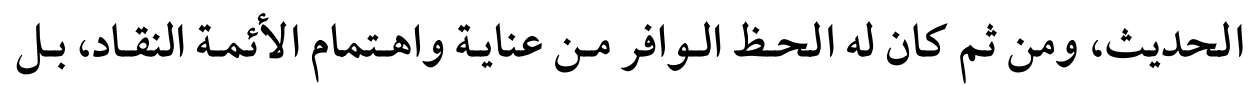
والباحثين المعاصرين المختصين بهذا الفن وفروعـه، حيـث تعـددت فيـه الدراسات والبحوث والحمد لله، وهنا أذكر ما وقفت عليه من البحوث ذات 
(9)

الصلة القريبـة لموضـوع دراسـتي ــ أعني مـا يخـص دلالـة المـصطلحات الخاصة في تجريح الرواة فقط ، ومنها ما يلي: (1 ) ألفاظ وعبارات الجرح والتعديل بين الإفراد والتكرير والتركيب ودلالية

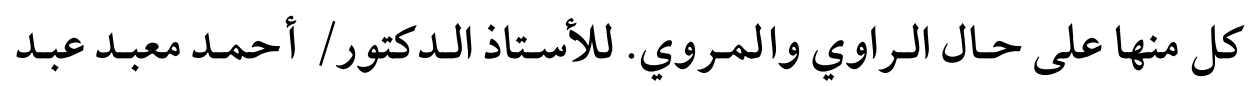

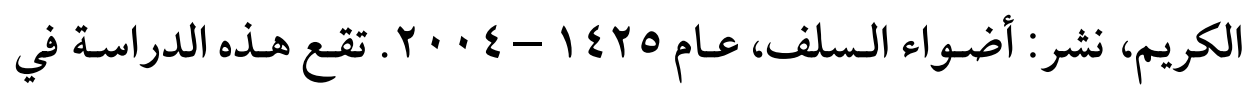
\& ص ص صفحة تقريباً. (Y) الاصطلاحات الخاصة في الجرح والتعديل في القرن الثالث الهجري للدكتور/ زياد محمد خضيري، جامعة الموصل بـالعراق. نشر مجلة كلية فئل العلوم الإسلامية ـ العدد الثاني عشر ـ المجلد السادس عشر ـ لعام بrع ا هـ. r Y r P م. هذا البحث يقع في ثلاثين صفحة من القطع الصغير، تناول ثمانيـة مصطلحات، ما بين جرح وتعديل وهي:(صدوق)،(اكتب عنه)،(شيخ)،(ثقـة صدوق)،(ليس بشيء)،(لا بأس به)،(مجهول)،(متكلم فيه). (r) أوفى الشرح في بيان اخـتلاف دلالة ألفـاظ الجـرح. للـدكتورة/ سـعاد جعفر حمادي، جامعـة الكويـت، نشر مجلـة الأنـدلس للعلوم الاجتماعية،

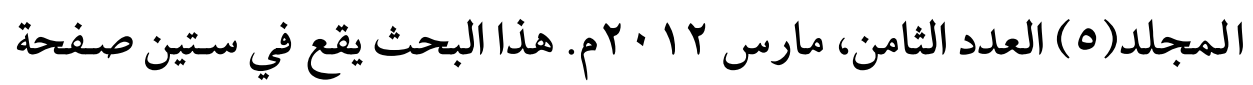
تقريباً، تناولت فيه الباحثة ثمانية ألفاظ للجرح، وهي: (ليس بالقوي ـ ضعيف ـ ليس بذاك ـ مجهول ـ ليس بشيء ـ سكتو اعنه ـ فيه نظر ـ منكر الحديث) . 


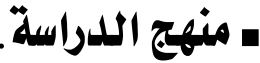

من المهم في بداية أي بحث علمي تحديد منهج البحثث الذي تسير عليه

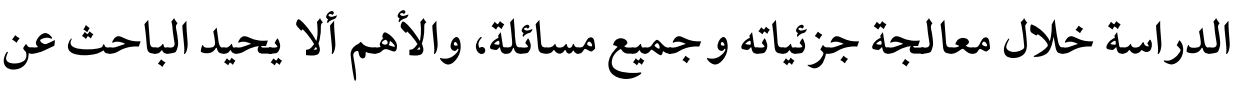

هذا المنهج، ويمكن تلخيص منهجي لهذا البحث في النقاط التالية:

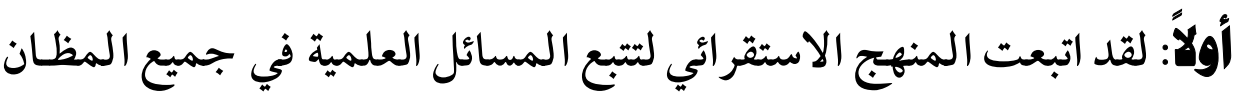

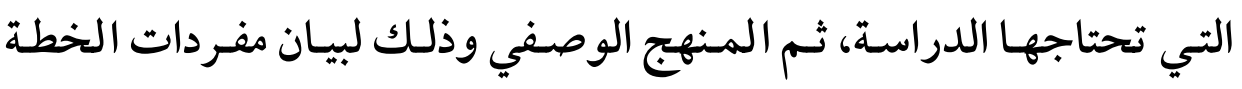

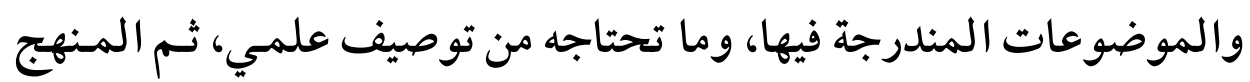
التَّليلي، وذلك لتحليل بعض الموضوعات واستجلاء النقاط الهامة فيها، من خلال جميع المصادر والمراجع التي تحتاجها الدراسة أيضاً.

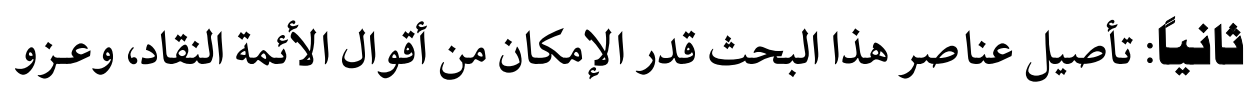

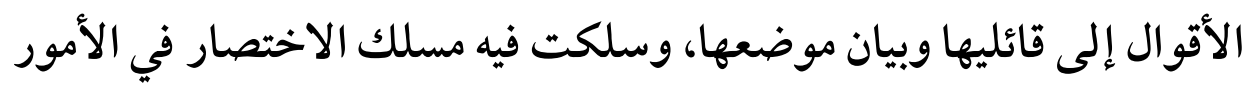

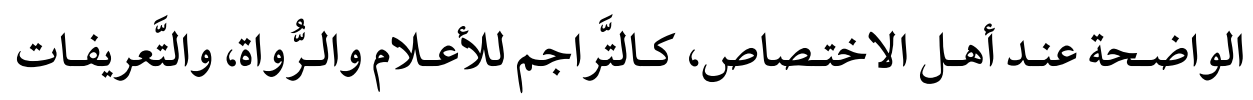
ونحوها. ثالثً: قسمت المصطلحات الخاصة التي أشرت إليها في حدود الدراسة

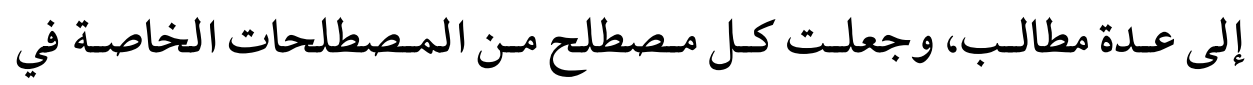

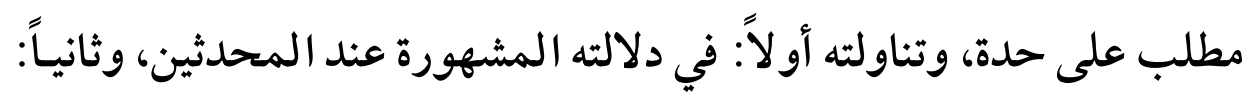

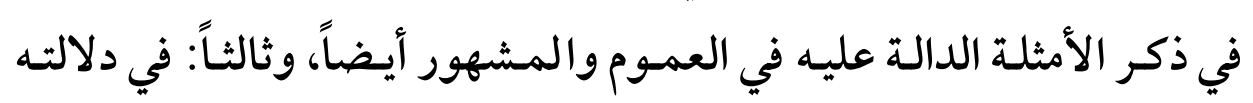

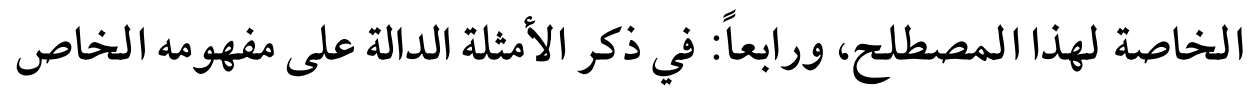

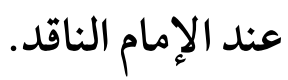


(II)

رابعَ: التزمت عند النقل من أي مرجـع، أو الاستفادة منه الإشـارة إلى رقم

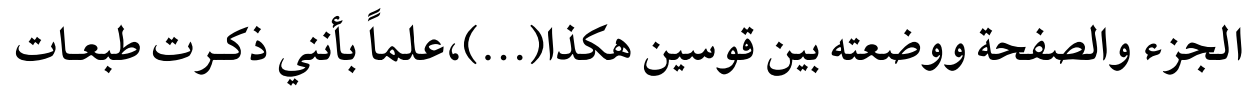
المراجع والمصادر مرتبة على حروف المعجم في الفهرس خشية الإطالة، وما ورد في الهامش من توثيتق المرجع برمز حرف (ت) إنما هـو اختصار

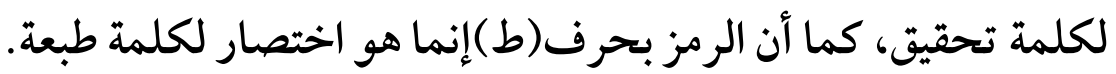
والله عز وجل أسال أن ينفع بما كتبت، وأن يتقبله خالصَا لوجهه الكريم. ـ خطة البحث: يتكون هذا البحث من مقدمة، ومبحثين، وخاتمة. ـ المقدمة : ذكرت فيها مشكلة البحث، وأهداف الدراسة، ثم حـدود البحـث، والدراسات السابقة، ثم المنهج العلمي، ثم الخطة البحثية.

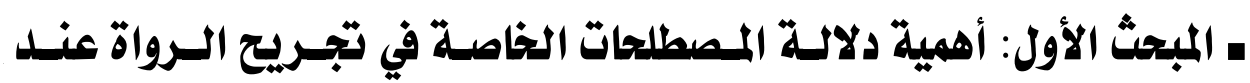

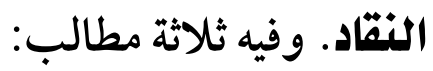
المطلب الأول: بيـان المعنى المقصـود مـن الدلالة، واستخدام المحـدثين لكلمة المصطلحات الخاصة. المطلب الثاني: طرق معرفة دلالات المصطلحات الخاصة للأئمة النقاد. المطلب الثالث: تعريف الجرح لغة واصطلاحاً، وأهميته في نقد الرواة. ـ المبحث الثاني: دراسة للالالة بعض المصطلحات الخاصـة الـتي في ظاهرهـا التجريج. وفيه خمسة مطالب:

$$
\text { المطلب الثاني: الأول: قولهم في الراوي: (يسرق الحديث). }
$$


(IY)

$$
\begin{aligned}
& \text { دلالة المصطلحات الخاصة بين النقاد في تجريج الرواة (دراسة وتحليل) } \\
& \text { المطلب الرابع: قولهم في الراوي: (لاشيء). } \\
& \text { المطلب الخامس: قولهم في الراوي: (ليس بمشهور). } \\
& \text { ـ الخاتقة. ذكرت فيها أهم نتائج الدراسة. } \\
& \text { ـ الفهارس. فهرس المصادر والمراجع، وآخر لمحتويات البحث. }
\end{aligned}
$$

الباحث 
(Ir)

\section{المبحث الأول: أهمية دلالة المطالهات الخاصة في تجريج الرواة}

\section{عند النقاد.}

إن مما يتطلبه البحث العلمي الـدقيق تحديـد سير البحثث، ومـن مقتضيات

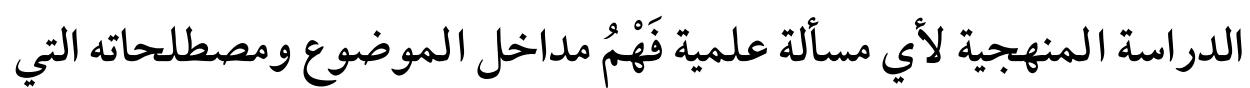

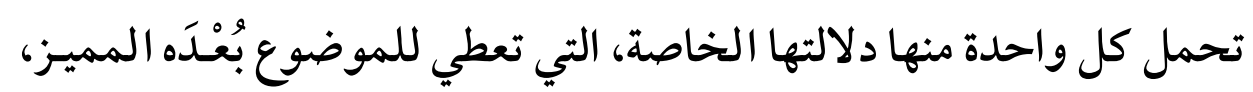

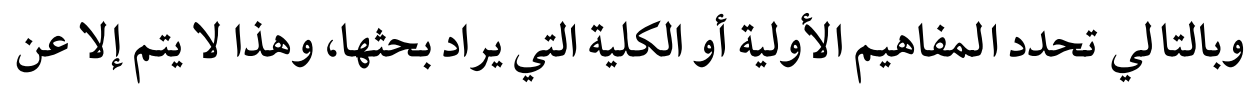
طريق الخطوات التالية: - ماتين أولاً: تحديد المفاهيم الأساسية لمصطلحات هذا لخات البحث. ثانياً: بيان الخطة العلمية لمسائله. ثالثاً: المنهج العلمي المتبع في عرض هذه المسائل المئل وكيفية المعالجة. ـ أما عن خطة هذا البحث، ومنهج الدراسة فيه، فقد سبقت الإشارة إليهما في المقدمة، بقي لنا أن نحدد المفاهيم للمصطلحات الأساسية التي يتكون منها هذا البحث، وإلقاء الضوء على هذه المفاهيم، وذلك على النحو التالي: ـ وبالنظر في موضوع هذا البحـث (دلالة المصطلحات الخاصـة بين النقاد

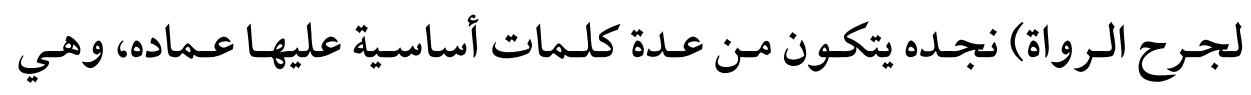
الجمل: (دلالة)،(المصطلحات)،(التجريح)، ولنعرض بالتحليل والدراسـة لكل كلمة على حدة. 
(।乏) دلالة المطلحات الخاصة بين النقاد في تبريح الرواة (دراسة وتحليل)

ـ وقبل أن أبدأ في عرض وتحليل المصطلحات الأساسية التي يتكون منها

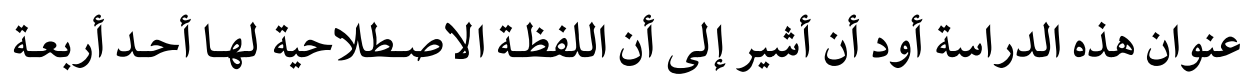
(1) معانٍ، كما يلي الأول: المعنى اللفـوي؛ فالكلمـة إذا وجـدتها في سـياق لغوي فهي مستعملة بالمعنى اللغوي، أي الذي وضـعها لـه واضـع اللغـة، وهـو المعنى المـذكور ذكراً أساسياً في المعاجيم اللغوية القديمة . وكثير من المحدثين يستعملون الكلمة الاصطلاحية في كثير مـن الأحيان، بمعناها اللغوي، لا الاصطلاحي، وقد حُملت كلمات كثيرة للمحدثين، على

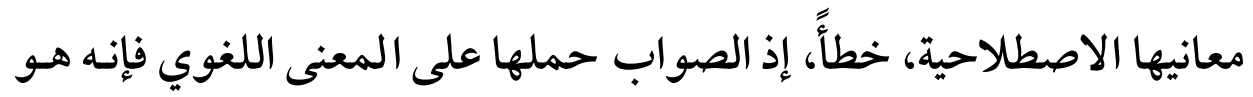
الذي عناه صاحب تلك الكلمة . الثـاني: المعنـى الهشرعي؛ فإذا وجـدتها في سياق شرعي أي في العبـارات الدينية في أي كلام ملفوظ أو مكتوب: فهي مستعملة بـالمعنى الشرعي أي الذي وضعها له الشارع، مثل الصلاة والصوم والزكاة.

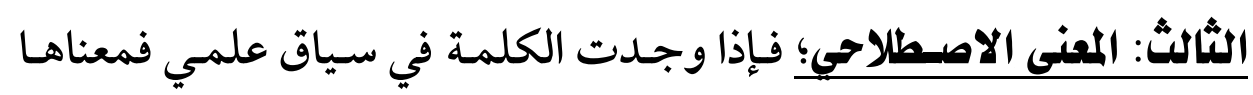
اصطلاحي وهو الذي وضعها له أهل ذلك العلم .

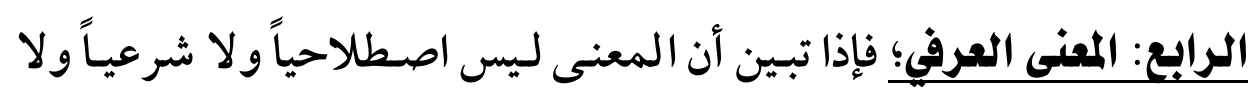

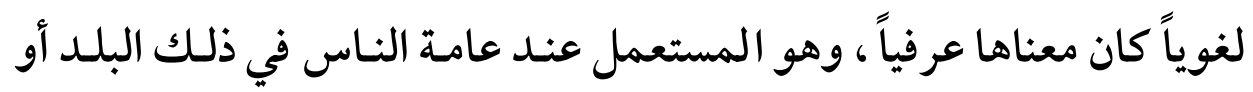
المكان، وينبغي أن يقدم المعنى الذي يدل عليه السياق كما تقدََّمَ، دون سـائر

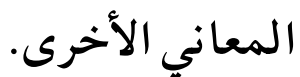

(1 ) لسان المحدثين (معجم مصطلحات المحدثين) ( / / I ) . 
(10)

الاملب الأول: بيان المقصود هن لفظة (الدلالة) واستخدام المددثين

لعبارة (الإصطات الفاصة).

أولاً: لفظة ( الدلالة) في اللفة.

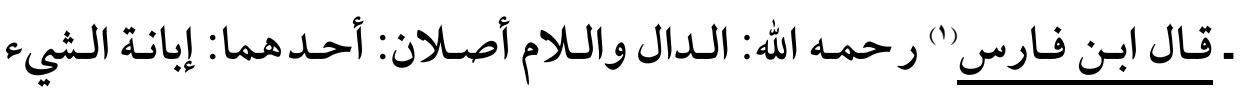
بأمارةٍ تتعلمها، والآخَر : اضطرابٌ في الشيء. فـالأوَّل قولهم: دلَلْتُ فلانَّا على الطريق. والدليل: الأمارة في الثيء. وهو بيِّن الدَّلالة والدّلالة. (") ـ في القـر آن الكـريم: وردت مـشتقات مـن لفظظ الدلالـة في سـبعة مواضـع،

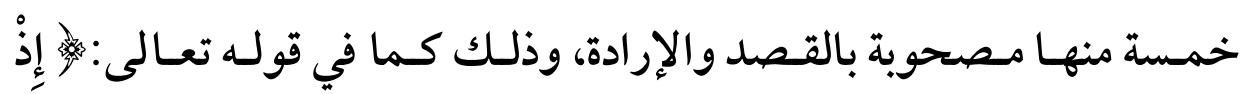

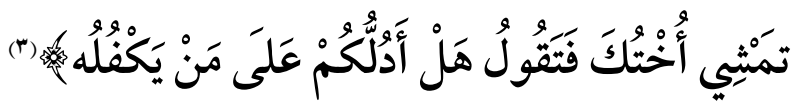

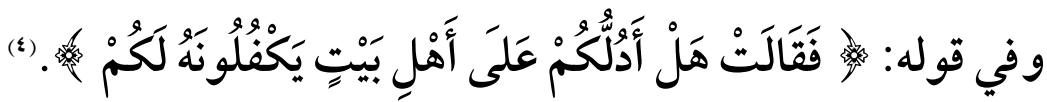

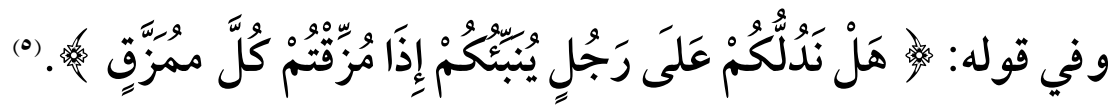

(1) أحمد بن فارس بن زكريا بن حبيب، أبو الحسين،اللغوي، القزويني، كان شافعيا،

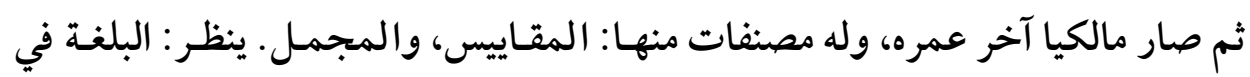
تراجم أئمة النحو واللغة (ص: • م).

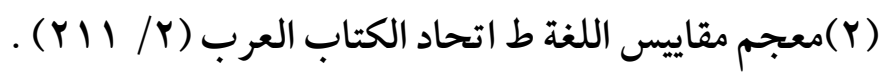
. $[\varepsilon \cdot: ط](r)$ ( ) (القصص: Ir] . (0) 
(17)

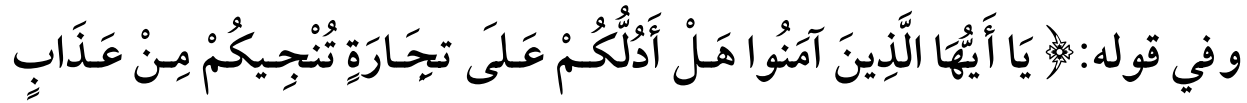

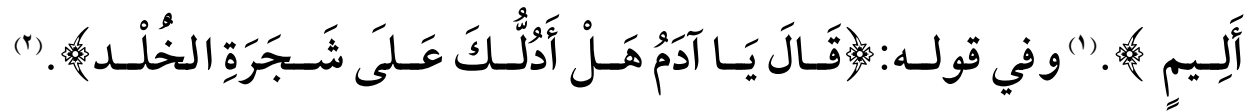

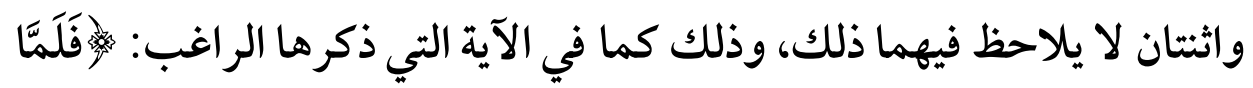

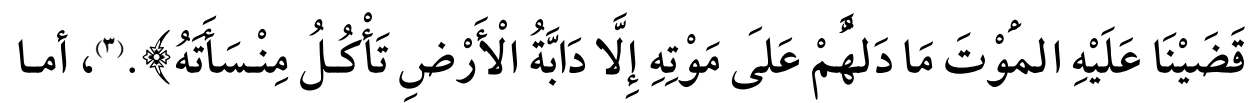

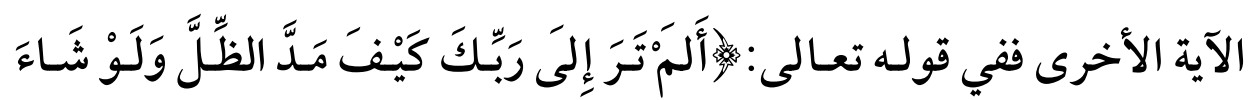

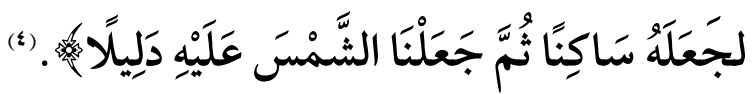
ـوفي الحديث: أخرج الإمام مسلم في صحيحه من حديث أَبَي هُرَيْرَةَّة قَالَ:

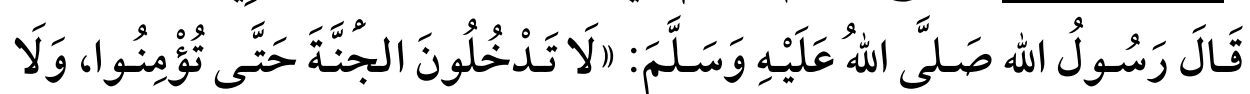

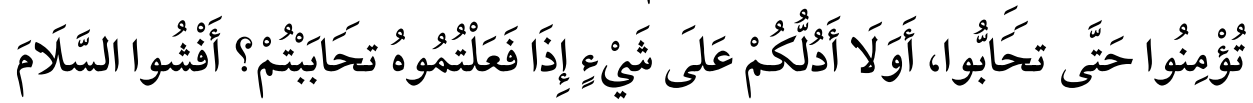
(0) بَيْنَكُمْ (1) الحديث بيَّن أثَرَ إفشاء السلام بين الناس، وقد دل رسولُ الله صلى الله عليه

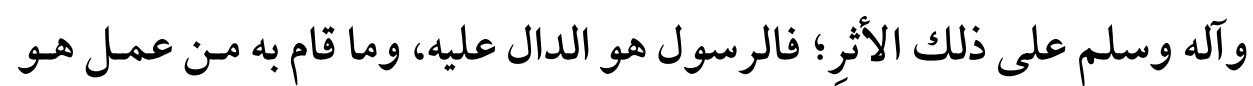

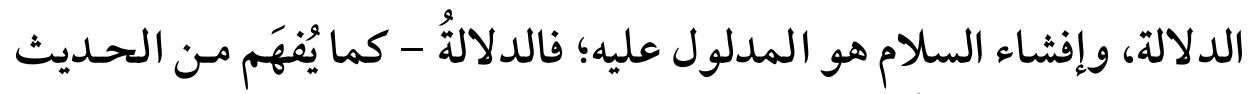
- هي ما يقوم به الدالّ من عمل، أو ما يؤدِّيه من وظيفة.

$$
\begin{aligned}
& \text { (1) [الصف: •1] }
\end{aligned}
$$

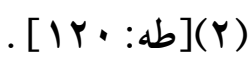

$$
\begin{aligned}
& \text { (r) } \\
& \text { ( ) [الفرقان: } 8 \text { ـ] . }
\end{aligned}
$$

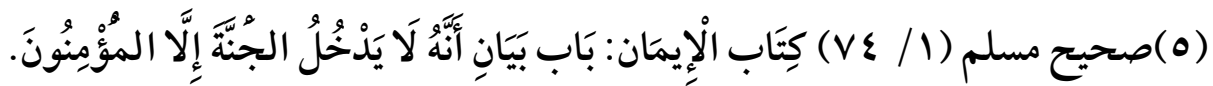


ـ وقـال الراغـب(1): مـا يتوصّل بـه إلى معرفـة الشيء، كدلالـة الألفـاظ عـلى المعنى، ودلالة الإشارات، والرموز، والكتابة، والعقود في الحساب، وسواء

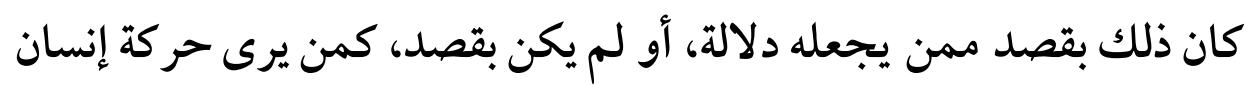

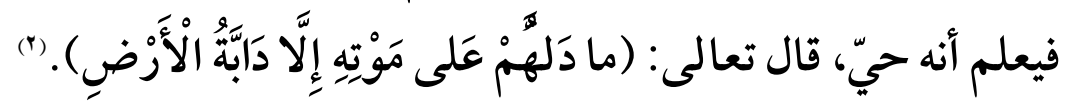

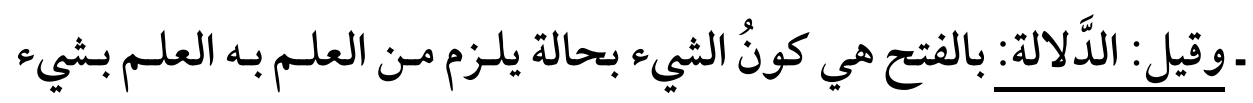

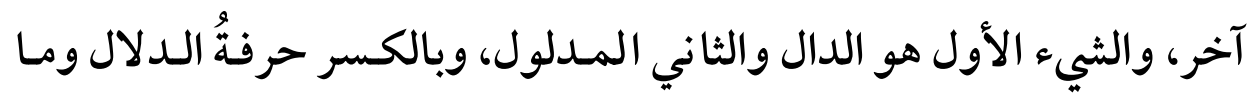

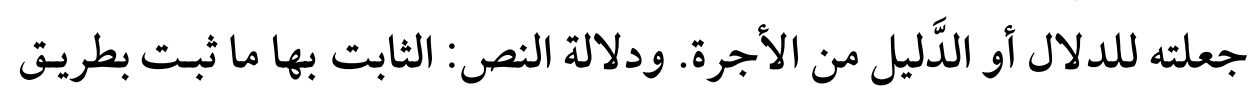
الأولوية بالمعنى اللغوي كالنص، مثاله النهيُ عن التأفيف في قوله تعـالى:

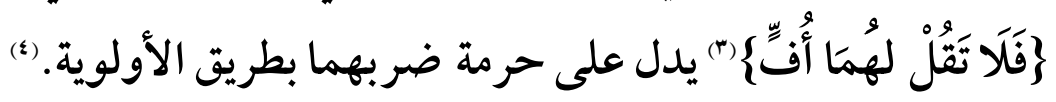

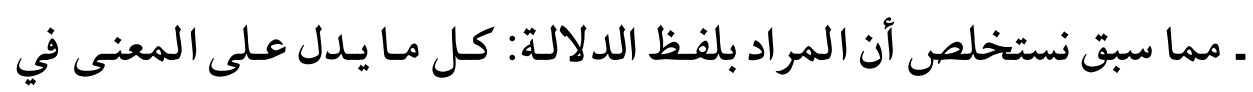
التر اكيب والألفاظ، حيث تتجلى المعاني، ويتضح المقصود. ـ الدلالة في عرف المحدثين.

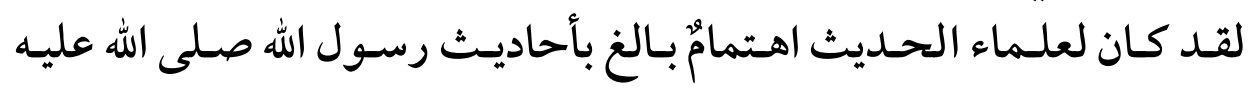
وسلم، وجعلوا للتعامل مع الألفاظ التي تقنن درجة الراوي من حيث العدالة والضبط قواعد تضبط مسالك الفهم وتضيء مسارب الاسـتنباط، وتعصم

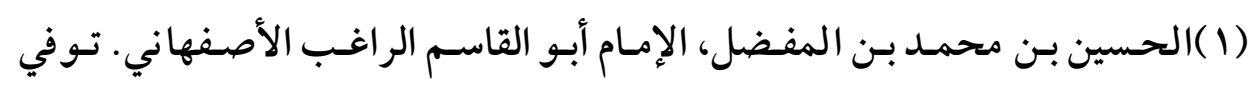

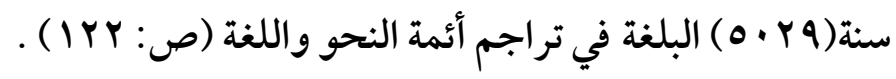

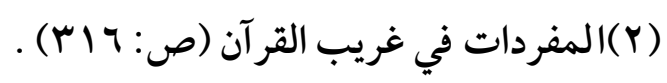

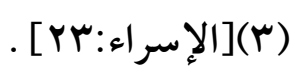

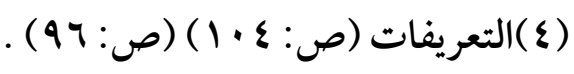


(1A)

الأفكار من غي الخطأ ومن مزالق الزلل والضلال والوهم، وإليك المزيد في

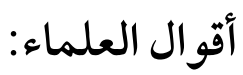
ـ قال ابن دقيق العيد'(') عن دلالة اللفظ من الناحية السياقية: فإن السياق طريـق إلى بيان المجملات وتعيين المحتملات وتنزيل الكلام عـلى المقصود منه وفهم ذلك." (") ـ وقـال ابـن القيمب"): السياق يرشـد إلى تبيين المجمل، وتعيين المحتمل، والقطع بعدم احتمال غير المر اد، وتخصيص العـام، وتقييد المطلق، وتنوع

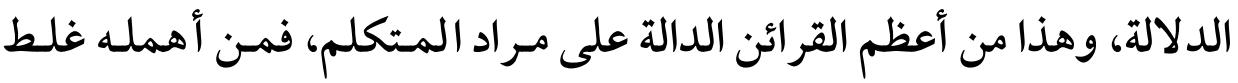
في نظره، وغالط في مناظرته. ـ و مما سبق في كلام ابن دقيق العيد وابـن القيم نرى نوعـاً واحسداً مـن أنواع الدلالة، وهو الدلالة السياقية، واللفظة قد يكون لها دلالتان(ب):

(1) الإمام الفقيه المحدث محمد بن علي بن وهب بن مطيع القشيري المعروف بابن

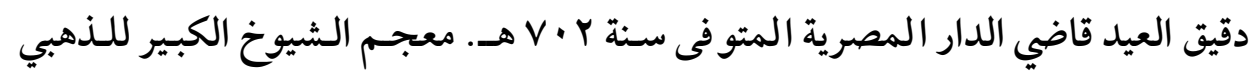
$(r \leqslant 9 / r)$

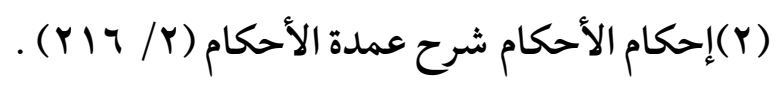

(r) محمد بن أبي بكر بن أيوب بن سعد الزرعي ثم الدمشقي الفقيه الأصسولي المفسر

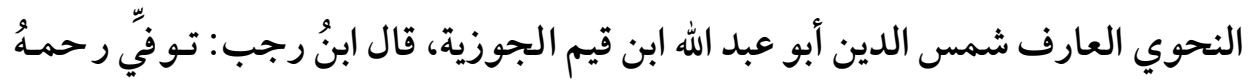

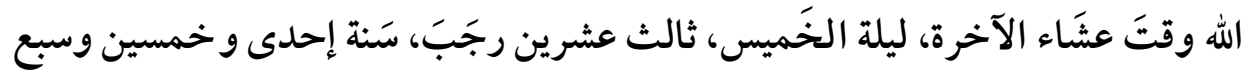

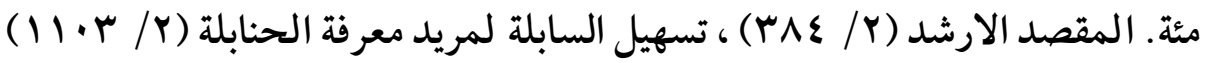

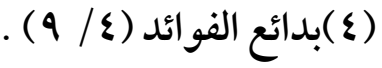

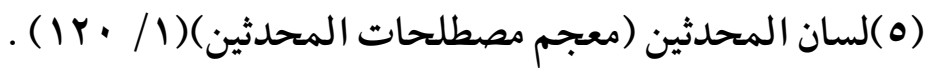


(19)

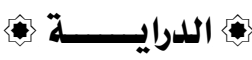

الللالة الأولى: الأصلية،(اللفظية) أي دلالة الكلمة باعتبار ذاتِها مجردةً عـن

سياقها، وهي التي يحصل الاستقر اء من أجلها، ويصاغ التعريف لتوضيحها.

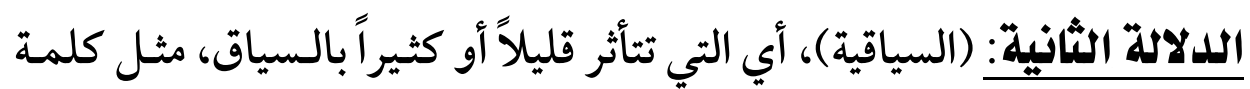
(ثقة) لها في نفسها معنى مشهور عند الجمهور، وهو العدالة والضبط، ولكن

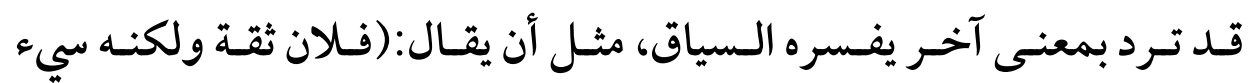

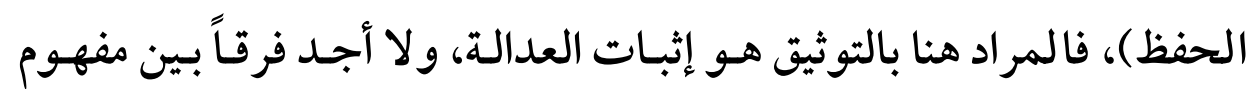
الدلالة عند أهل اللغة والمحدثين. 
$(Y \cdot)$

دلالة المطلحات الخاصة بين النقاد في تجريح الرواة (دراسة وتحليل) ثانياً: استخدام المحدثين لعبارة (المصطلحات الخاصة). ـ كلمة (مصطلح) في المعنى العام.

وتتر ادف كلمـة "مصطلح" وكلمـة "اصطلاح" في اللغـة العربيّة، و همـا مشتقتان من الفعل "اصطلح" (وجذره صلح) بمعنى: اتفق؛ لأنّ المصطلح

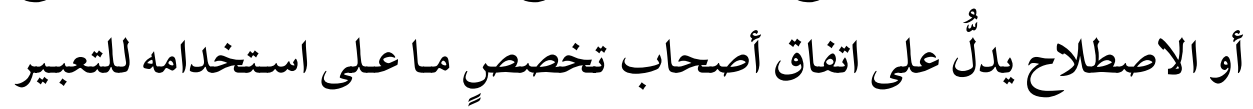

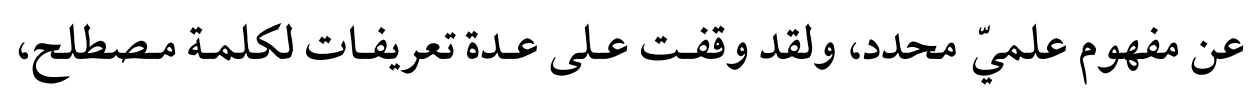
منها ما يلي: (أ) كلمـة مـصطلحات جمـــ مـصطلح، ويقــال: اصـطلاح أيسضاً، وعرفـهـ

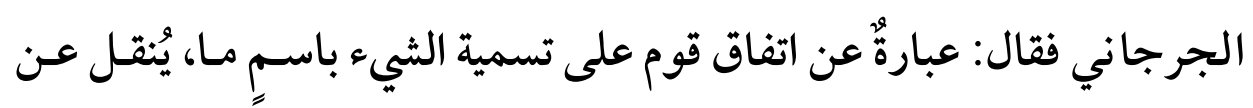

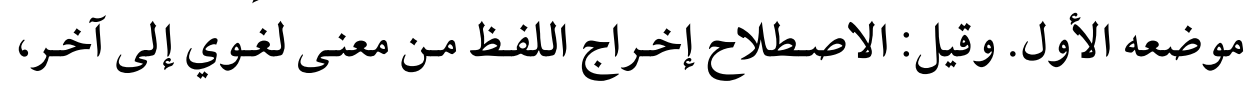

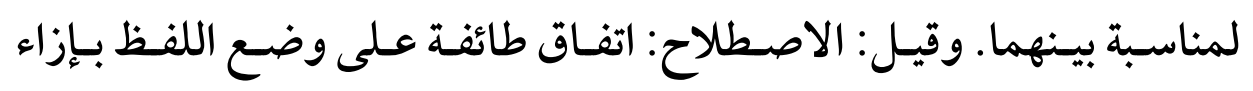

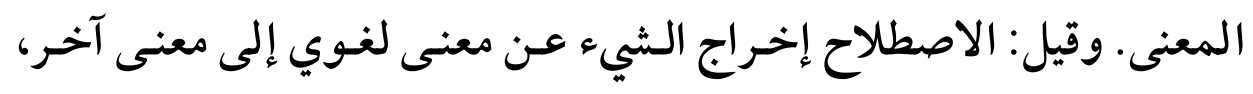

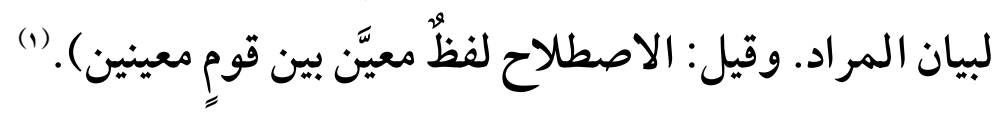

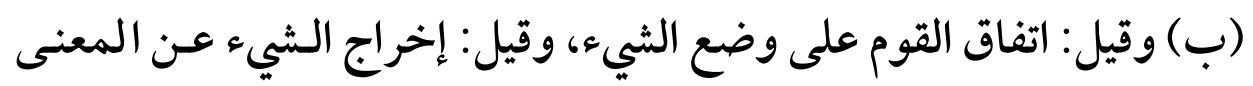

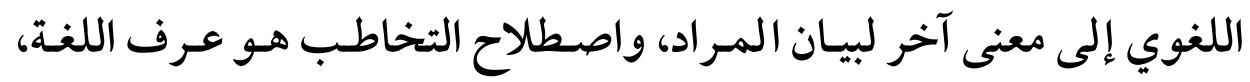

$$
\text { والاصطلاح: مقابل الشرع في عرف الفقهاء. (r) }
$$

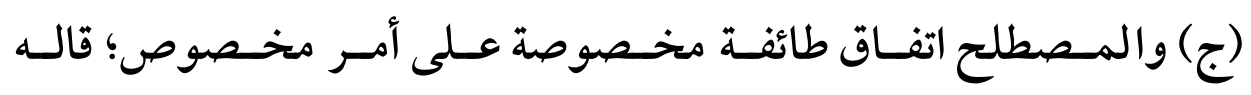
الخفاجي. (r)

$$
\begin{aligned}
& \text { (1) (Y) (Y) (Y) . }
\end{aligned}
$$

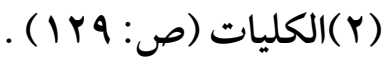

$$
\begin{aligned}
& \text { (r) تاج العروس (Y) (Y) (1) (1). }
\end{aligned}
$$


(YI)

(د) وقيل: اتفاق أهل علم من العلوم أو صـناعة مـن الصناعات أو عمـل مـن

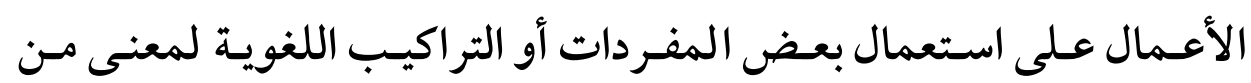

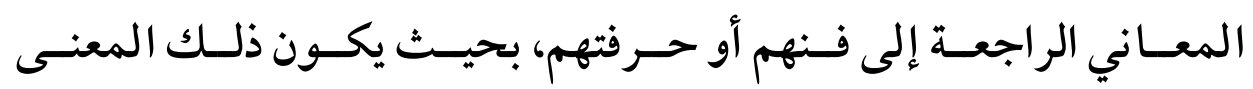

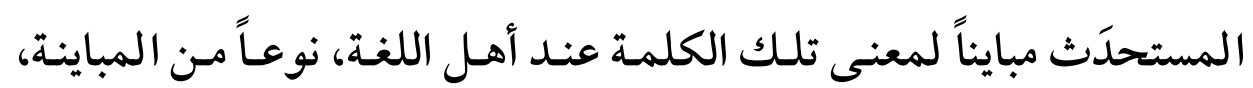
ويكثر الاصطلاح في المعـاني التي يكثر دورانها عـلى ألسنتهم أو يكثر

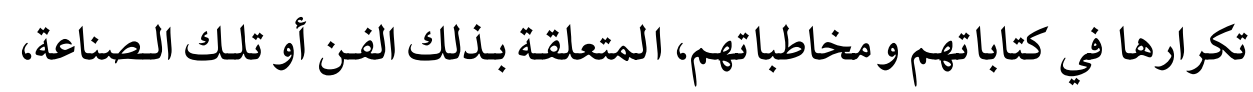

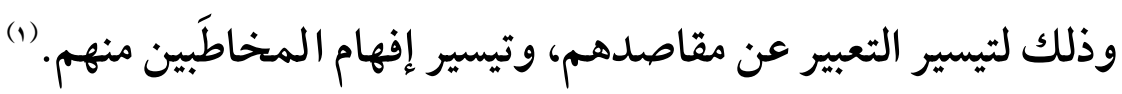
ـ عبارة (المصطلحات الخاصة) من منظور المحلدثين.

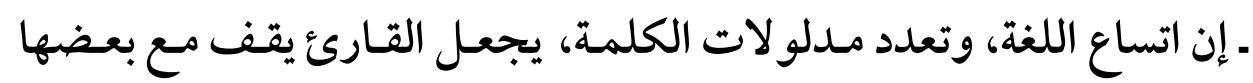
موقف المتردد في تنزيلها على أي المدلو لات التي ظهرت له، فإذا مـا كانت

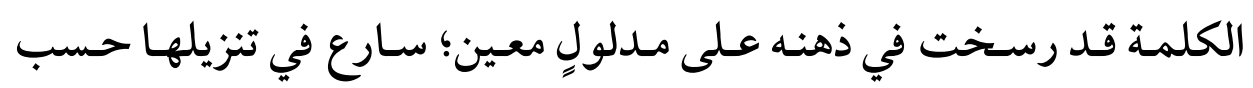

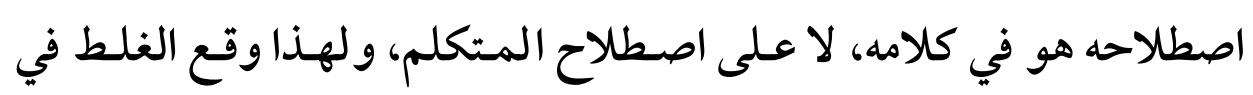
الفهم والاستـلال في شـتى الفنون؛ بسبب العزوف عـن فهـم مصطلحات

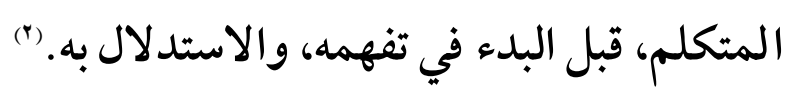

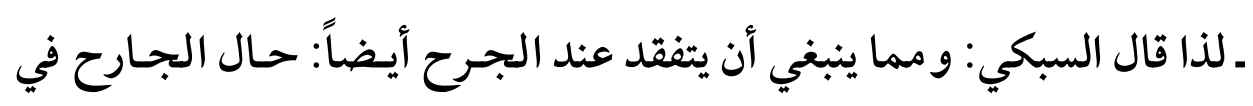

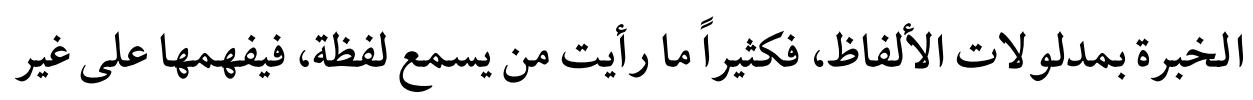
وجهها؛ والخبرة بمدلو لات الألفاظ؛ ولاسيما العرفية التي تختلف باختلاف

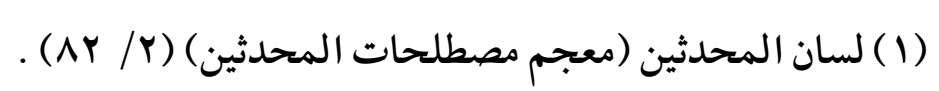

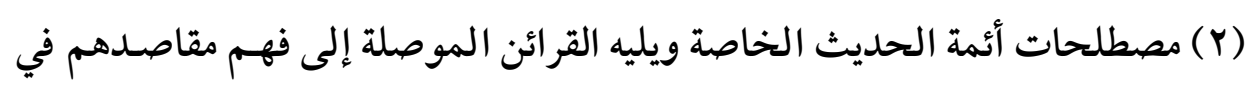

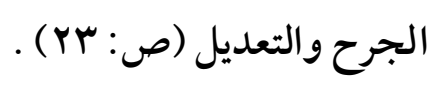


(YY)

دلالة المطلحات الخاصة بين النقاد في تجريح الرواة (دراسة وتحليل)

عرف الناس، وتكون في بعض الأزمنة مدحاً، وفي بعضها ذماً، أمر شـديد، لا يدر كه إلا قعيدٌ بالعلم. (1)

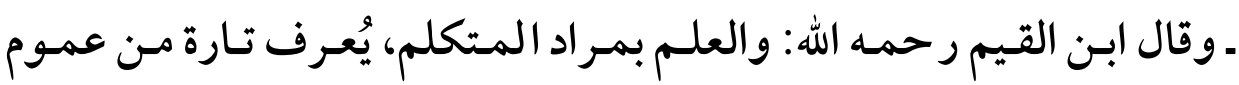

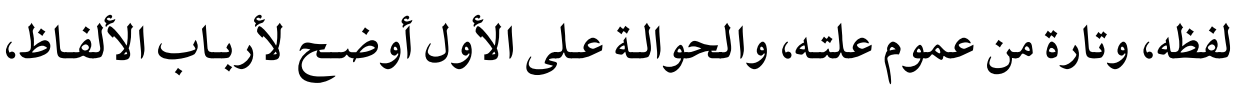

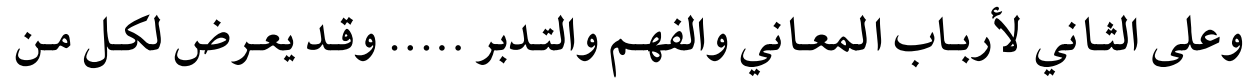
الفريقين، ما يخل بمعرفة مر اد المتكلم، فيعرض لإبـ لأربـاب الألفـاظ، التقصير

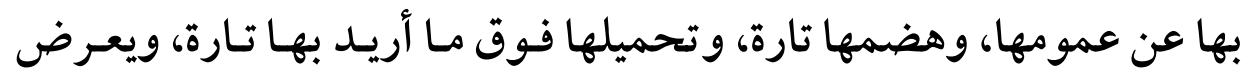
لأرباب المعاني فيها نظير ما يعرض لأرباب الألفاظ، فهذه أربع آفات هي وهي منشأ غلط الفريقين. (r)

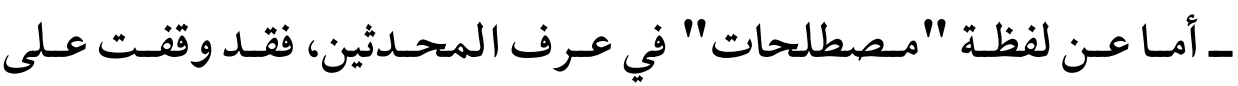
مجموعة من الضوابط التي قد تجلي لنا الكثف عـن مـراد علماء النقــــــها،

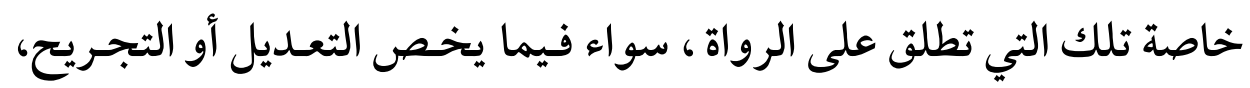

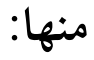
(أ)المصطلحات جمع مصطلح، من باب الافتعال قلبت تاؤها طاءاً، وأريـد بها ههنا: ألفاظ مخصوصة موضوعة لمعان يمتاز بعضها عن بعض باعتبار قيد يميزه عنه وسبب إطلاقها عليها هو الاتفاق على وضسعها لتلك المعـاني

$$
\text { (1) قاعدة في الجرح والتعديل (ص: به ) . }
$$

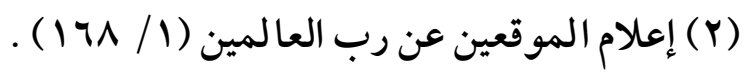


لتحصل عند استعما لها مـع أداتها اصطلاح المعاني ودفع فساد التباسها بعضها ببعض. (1) (ب) قال طاهر الجزائري"): الاصطلاح اتفاق القوم على استعمال لفظ في

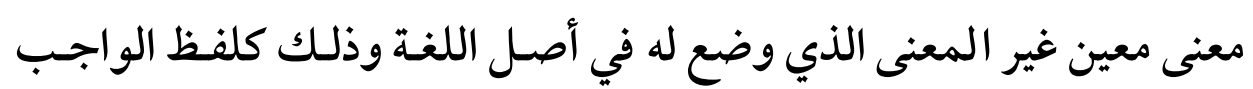

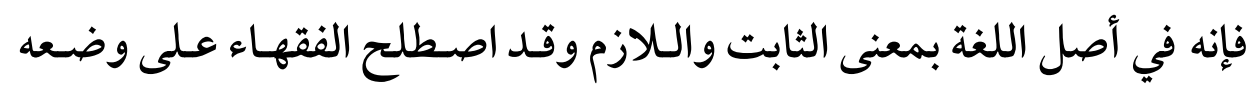

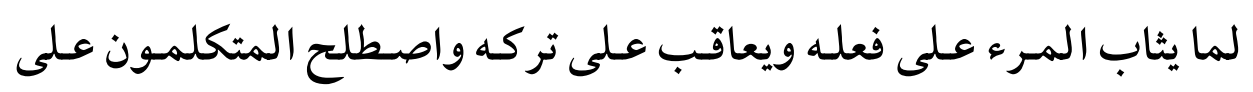
وضعه لما لا يتصور في العقل عدمه، واللفظ إذا استعمل في المعنى الذي لـي وضسعه لـه المـصطلحون يكـون حقيقـة بالنسبة إلـيهم و مجـازا بالنسبة إلى لى غـيرهم؛ قـال في(المفتـاح): الحقيقـة هـي الكلمـة المستعملة في معناهــا بالتحقيق؛ والحقيقة تنقسم عند العلماء إلى لغوية وشرعية وعرفية؛ والسبب

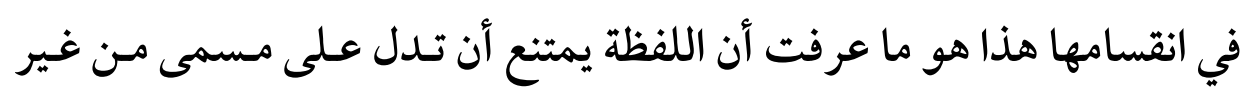

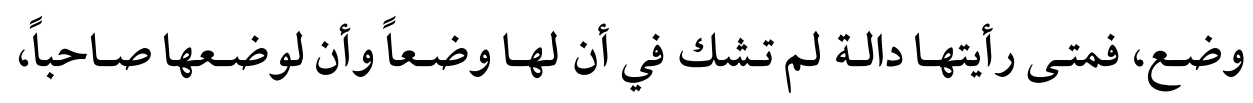

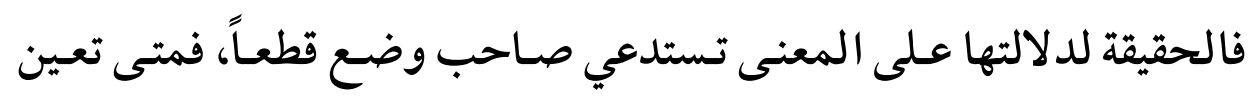

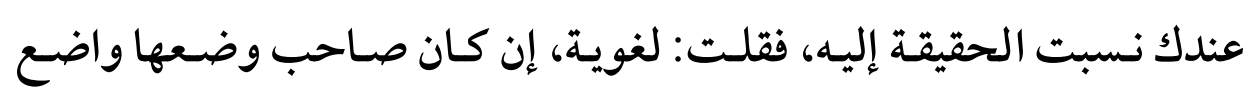
اللغـة، وقلـت: شرعيـة إن كـان صـاحب وضـعها الـشارع؛ ومتـى لم يتعسين

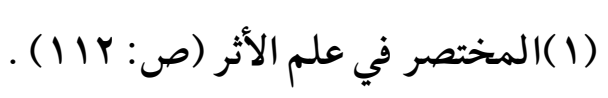

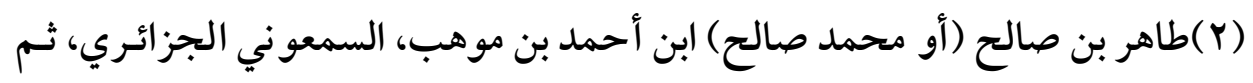

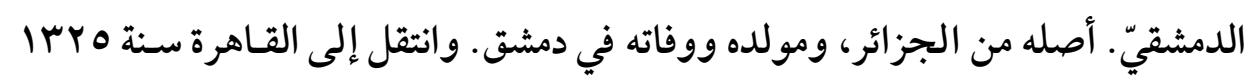

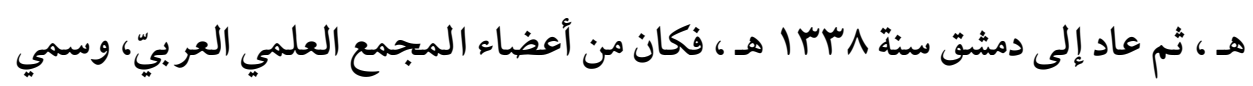

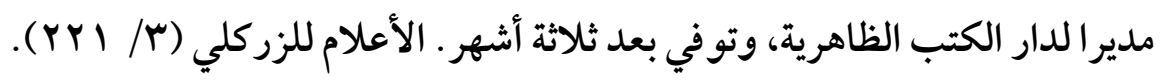


(Y乏)

دلالة المطلحات الخاصة بين النقاد في تجريح الرواة (دراسة وتحليل)

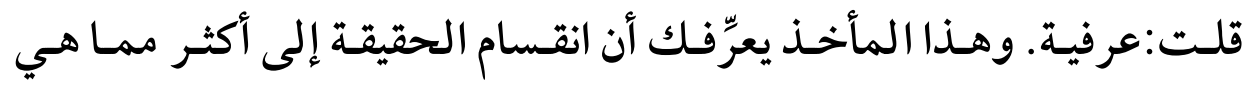

منقسمة إليه غير ممتنع في نفس الأمر. (1)

(ج) هي المصطلحات المختصة بهم؛ وهي جميع الكلمات التي استعملها

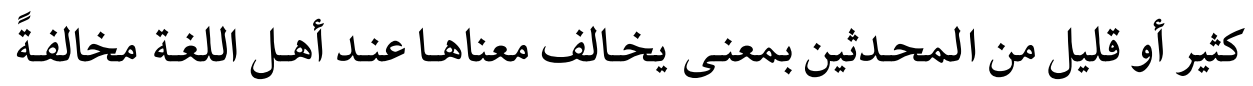

$$
\text { يسيرةً أو كثيرة، قريبةً أو بعيدة. (r) }
$$

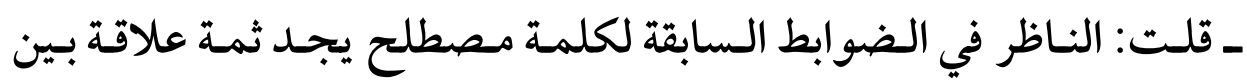

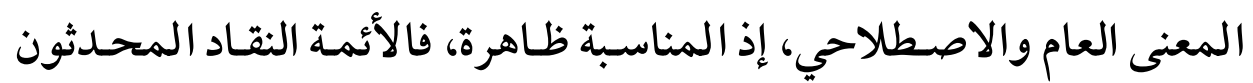
اسـتعملوا بعض المفـردات والتراكيـب الخاصـة بهـم في تجـريح وتعـديل

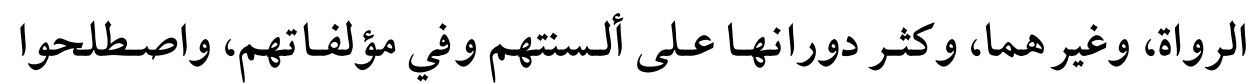
عليها فيما بينهم، حتى تعرف بها درجة الراوي من حيث القبول أو الرد.

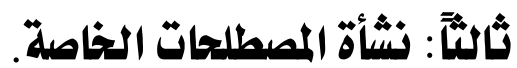
لقد نشأت مصطلحاتُ علم الحديث عموماً مع نشأة الرّواية، ونقلِ الحـديث الماهي

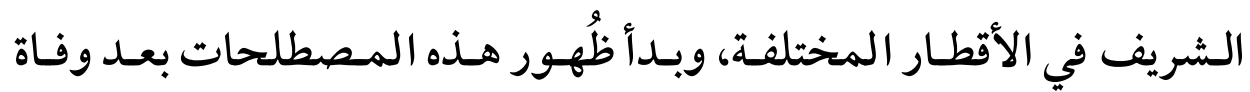
الرسول صلى الله عليه وسلم حين اهتمَّ المسلمون بجمــع الحـديث النبوي

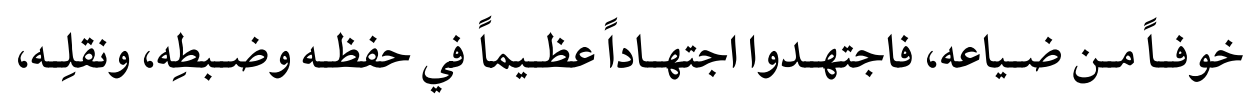

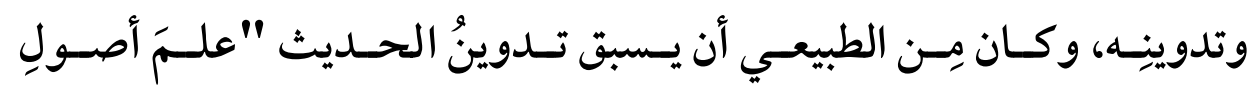

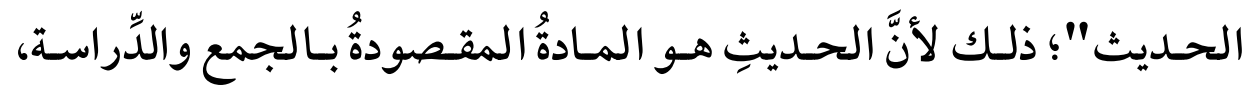

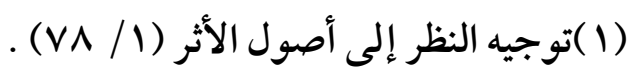
(Y) لسان المحدثين (معجم مصطلحات المحدثين) (1/ / 9 (1) ). 
(Yo)

و "أصولُ الحديث" هي القواعدُ والمنهاجُ الذي اتّبع في قبـول الحـديث أو

ردّّة، ومعرفة صحيحه من ضعيفه. (1)

ولقــد بـــأت تلـك المـصطلحات بدايـة ظـاهرة واضـحة في عهـد التـابعين، وكانت في أول أمرهـا قليلة في عـددها، ثم لم تزل تلك المصطلحات في

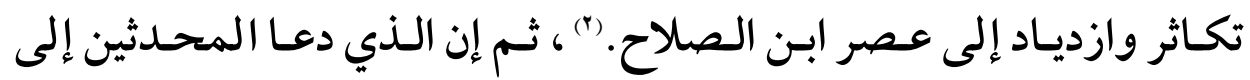
وضـع المـصطلحات الحديثيـة هـو حـاجتهم إلى تسهيل بيـانهم، وتقريسب مقاصدهم واختصار تعابيرهم كما فعل غيرهم مـن أربـاب العلوم والفنون الدينية والدنيوية.)

(1) معجم المصطلحات الحديثية (ص9 Y) للغوري.

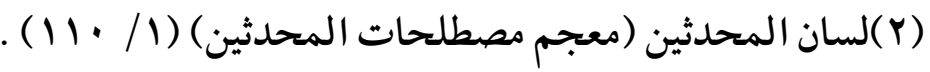

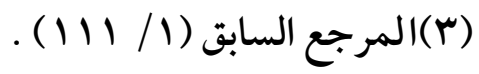




\section{الاملب الثاني: طرق همرفة دلالات الاصطلحات الخاصة}

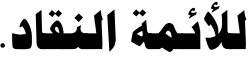

لمعرفة المصطلحات الخاصـة للنقـاد المحـدثين في جـرح وتعـديل الرواة والوقوف على دلالاتها أهمية كبرى؛ كي تأتي النتيجة على الراوي منضبطة وصحيحة.

ـ قال أبو الوليد الباجي (1). ... فعلى هـذا يحَمِل ألفـاظ آلجرح والتعـديل مَنْ

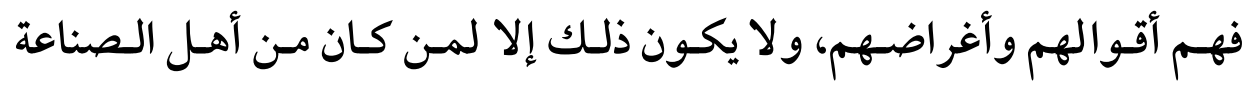
والعلم بهذا الشأن، وأما مَن لم يعلم ذلك، وليس عنده من أحوال المحـدثين إلا ما يأخذه من ألفاظ أهل الجرح والتعديل، فإنه لا يمكنه تنزيل الألفاظ هذا التنزيل، ولا اعتبارها بشيء مما ذكرنا، وإنما يتبع في ذلك ظاهر ألفاظهم فيما وقع الاتفاق عليه، ويقف عند اختلاف عباراتهم. (")

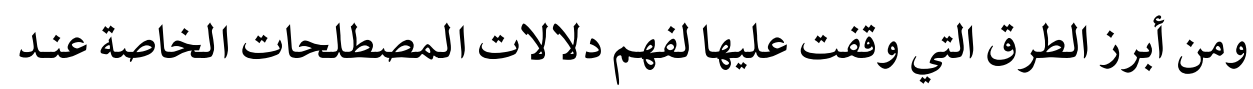
الأئمة النقاد، مع ذكر أمثلة لها من خلال كتب الرجال، ما يلي:

(1) أَبو الوليد، سليمانُ بن خلف بن سعد بن أيوب بن وارث التجيبي المالكي الأندليُّي

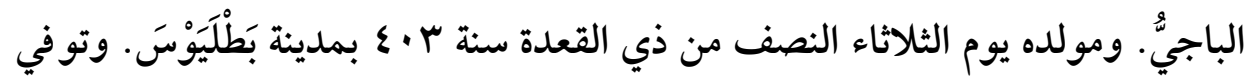

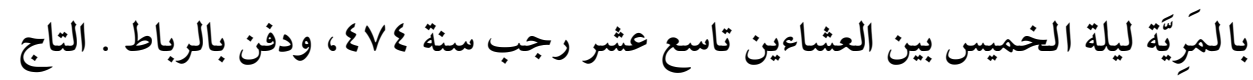

$$
\text { المكلل من جواهر مآثر الطراز الآخر والأول (ص: بـ ع ). }
$$

(Y) التعديل والتجريح ، لمن خرج له البخاري في الجامع الصحيح (Y / Y ) . 
(YV)

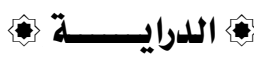

أولاً: أن يصرح الإمام الناقد بلدلالة المصطلح الذي أطلقه.

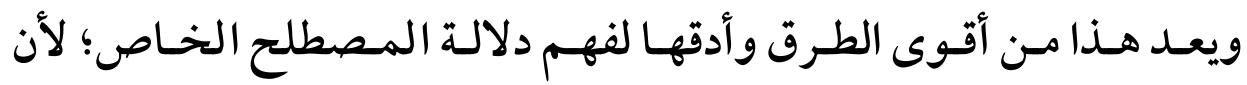
التصريح يقطع على الظن أي اعتبـار، ولهذا المسلك أمثلـة كثيرة في كتب

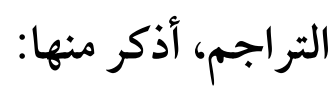

ـ قول الإمام البخاري: فلان في حديثه نظر، فهو متهم واهِ. ـ ونقل ابن القطان أن البخاري قال: كل من قلت فيه منكر الحديث فـلا تحل فئل

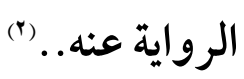

ـ وقول ابن أبي حـاتم عـن أبيـ: إذا قال: صـالح الحـديث، أي يكتب حديثه.

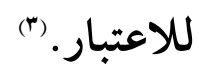

ـ وقول الذهبي: ثم اعلم أن كل من أقول فيـه مجهول، ولا أسـنده إلى قائل، فإن ذلك هو قول أبي حاتم فيه. (s) ـ وإذا قـال ابـن حجـر في الراوي مقبـول معنـاه: أي حيـث يتـابع، وإلا فلـين الحديث.

ثانياً: أن ينص أحلد الحفاظ على دلالة المصطلح للإمام الناقد.

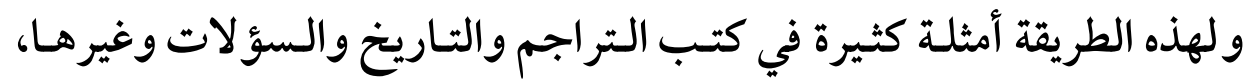

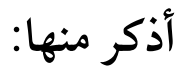

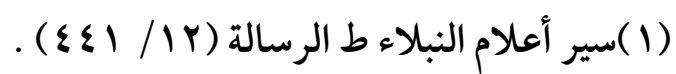
(Y) (Yيزان الاعتدال ( / ( ) .

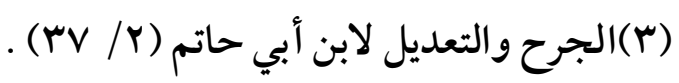
( ) (ميزان الاعثدال (1/ 7) . (0)تقريب التهذيب (1/ 1) . 
(Y^)

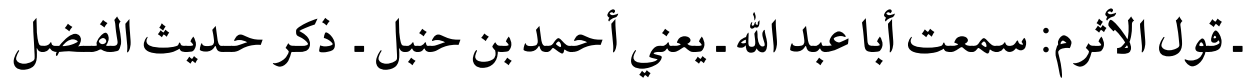

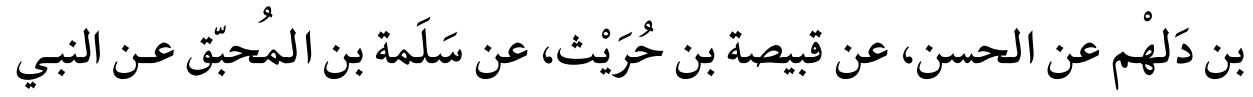
صلى الله عليه وسلم: خذوا عني، خذوا عني قد جعل الله لهن سـبيلاً، فقـال:

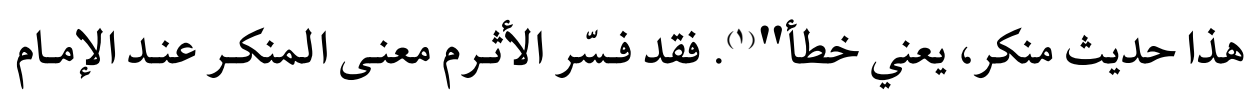
(") أحمد بأنه الخطأ...

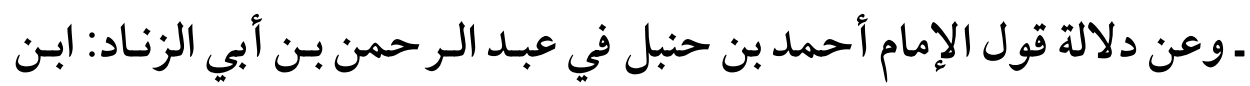
أبي الزناد كذا وكذا. قال العقيلي: يعني: ضعيف. (")

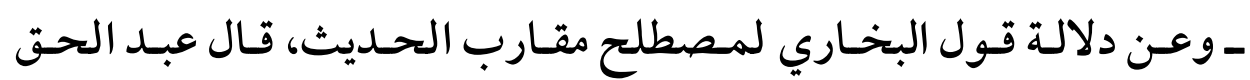
الأشبيلي في كتاب التهجد: يريد أن حديثه يقرب مـن حـديث الثقات، أي لا لا بأس به. (8) ـ وقال الأصمعي: نا قرة بـن خالد قـال: كانوا يـرون أن الكلبى " محمـد بـن

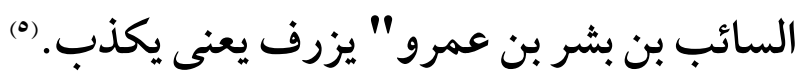

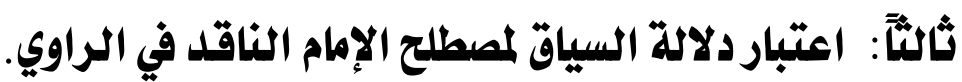

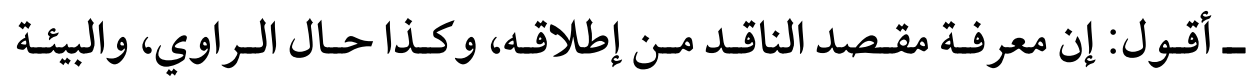
المحيطة به لأهمية كبيرة في بيان دلالة السياق للمصطلحات الخاصة.

$$
\begin{aligned}
& \text { (1) تهذيب الكمال في أسماء الرجال (YY / (Y ) (YY) . }
\end{aligned}
$$

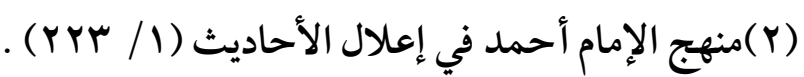

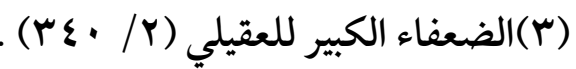

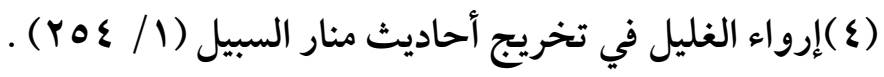

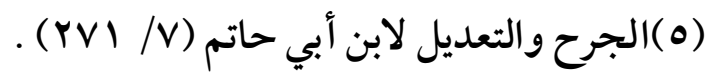


(Yq)

وقد بين شيخ الإسـلام ابـن تيميـة أهميـة اعتبـار هـذه الأمسور في تقييد دلالة

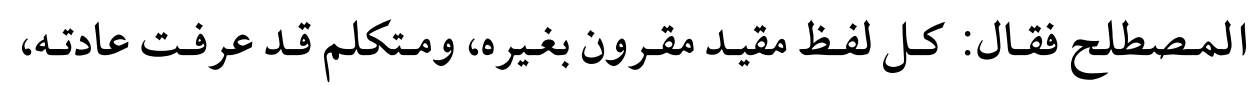
ومستمع قد عرف عادة المتكلم بذلك اللفظ، فهذه القيود لا بـد منها في كل كلام يفهم معناه، فلا يكون اللفظ مطلقا. (1) وبر أيي أن حال المخاطب بالعبارة أو اللفظة أيضاً مؤثرة في سياق المقام

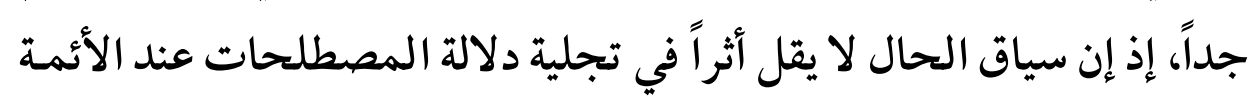

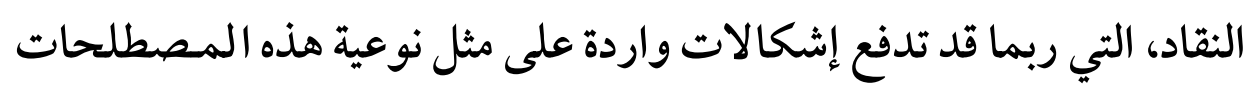
الخاصة، كما سيأتي في المبحث الثاني من هذه الدراسة.

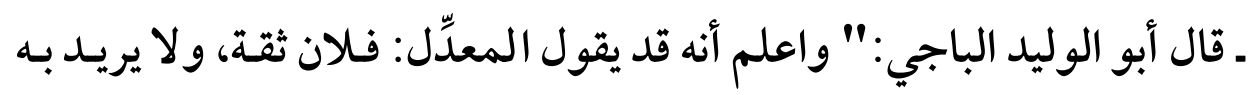

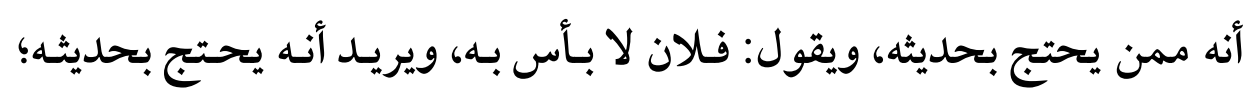

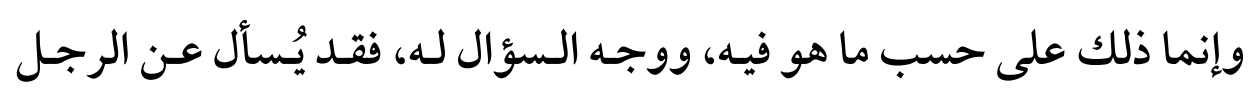

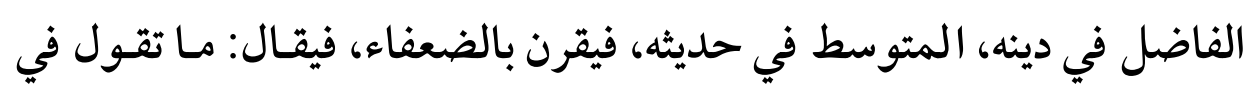

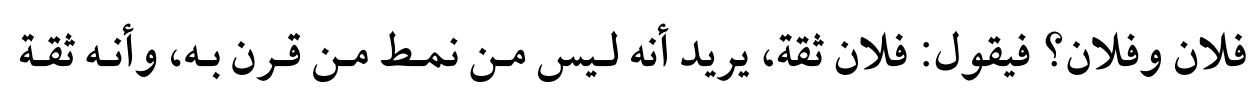
بالإضافة إلى غيره .. "(s) ولهذه الطريقة في فهم دلالات المصطلحات الخاصة أمثلة كثيرة في كتب الحب

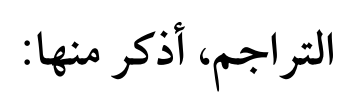
ـ ما جاء في الضعفاء الكبير للعقيلي: يونس الكذوب، قال: حدثنا عبد الله بـ

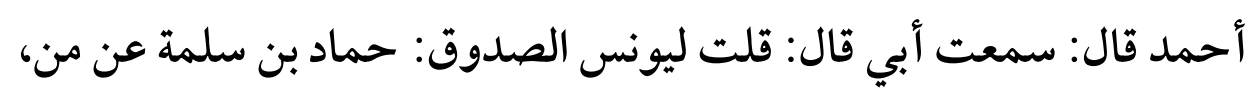

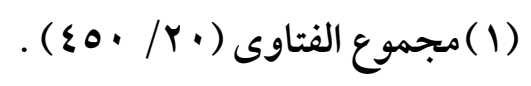

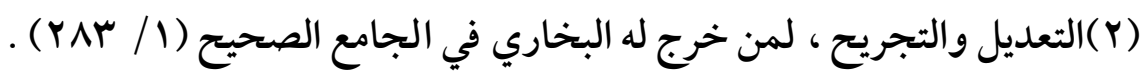


$\left(r^{\prime}\right)$

دلالة المطلحات الخاصة بين النقاد في تبريح الرواة (دراسة وتحليل)

كان يعيد في آخر عمره؟ قال: عن سعيد الجريري ، يعني يحـدث عنه ، قال

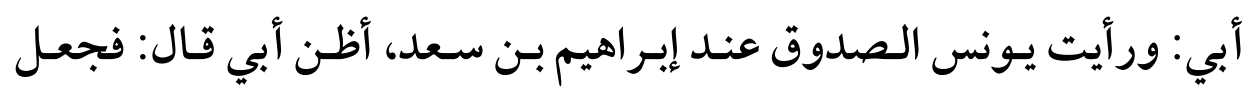

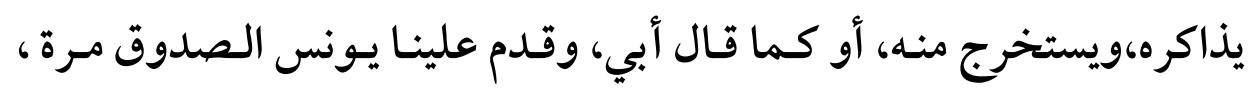

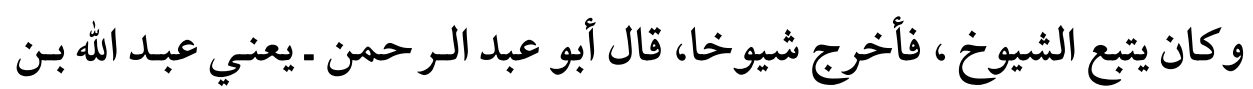

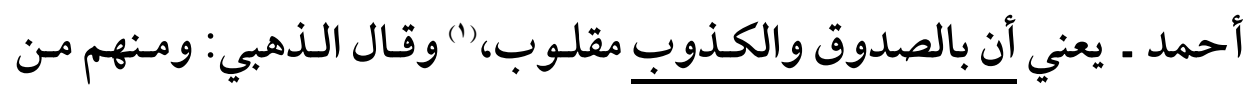
يقول فيه الصدوق على سبيل التهكم.. (") ـ وعن علي بن المـديني، قـال: سـئل يحيى بـن سعيد القطـان عـن مالك بـن

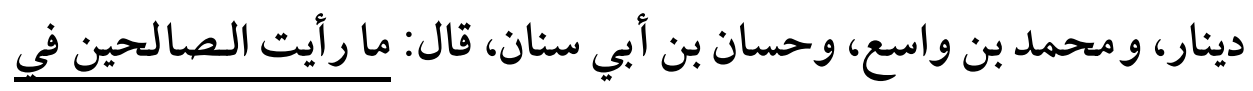
لهيء أكذب منهم في الحديث؛ لأنهم يكتبون عن كل من يلقون لا تمييز ـ وعن جعفر بن محمد الصائغ، يقول: اجتمع علي ابن المديني، وأبو بكر بن

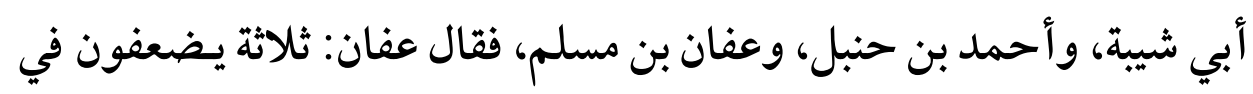

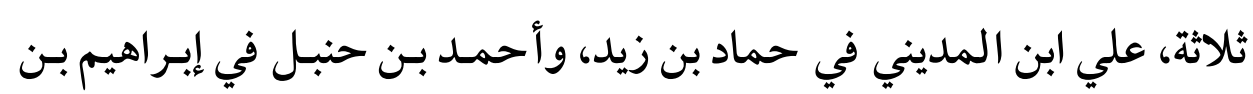

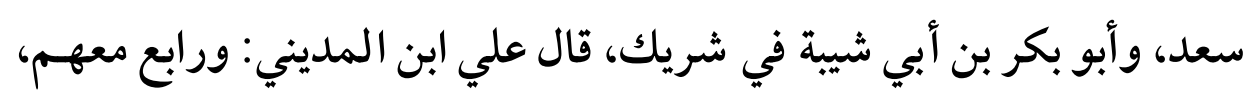

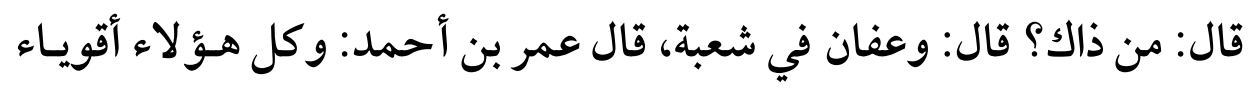
ليس فيهم ضعيف، ولكن قال: هذا على وجه المزاح.

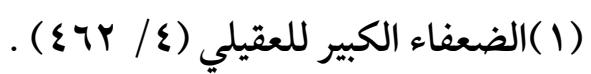

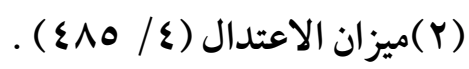

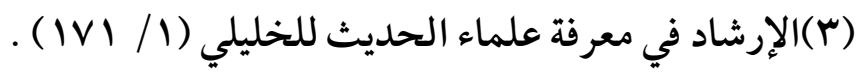

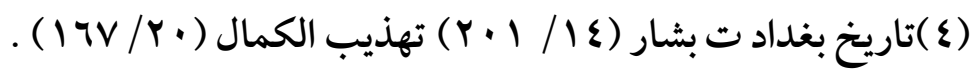


(r)

رابعاً: دلالة المصطلحات الخاصة عن طريق النظر في كتب اللفة والمعاجم.

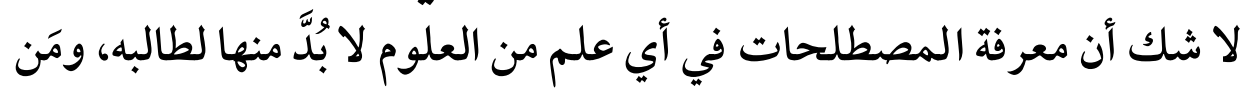

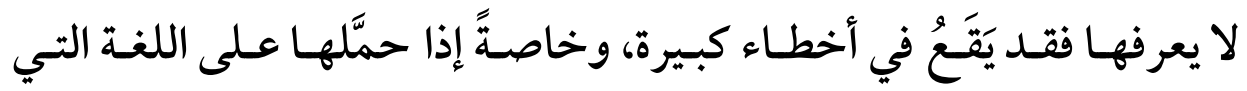
اعتادها، ثم فَهِمها على المعنى اللغوي. وقد ذكر المحققون أنه ينبغي لمن تكلم في فن مـن الفنون أن يسورد الألفـاظ

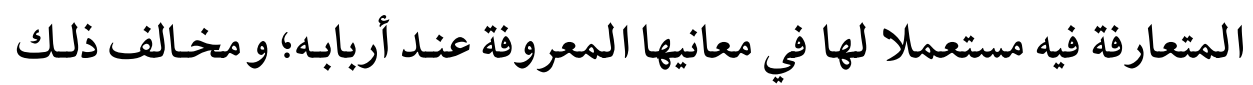
إما جاهل بمقتضى المقام، أو قاصد للإبهام أو الإيهام . (1) ومن الأمثلة على الدالة على هذا المسلك لدى أئمة النقد، ما يلي: ـ قد يسمون الخطأ كذباً، ففي تر جمة بـرد مـولى سعيد بـن المسيب القـرشي المدي.

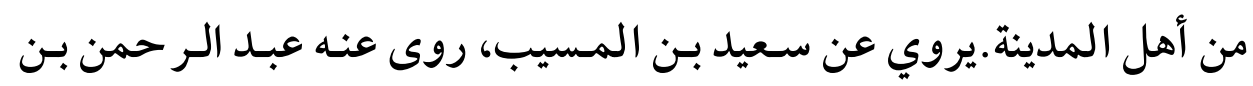

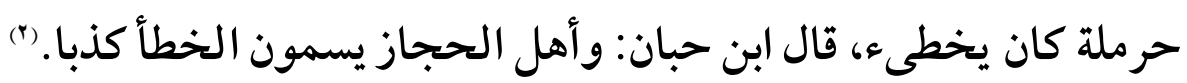

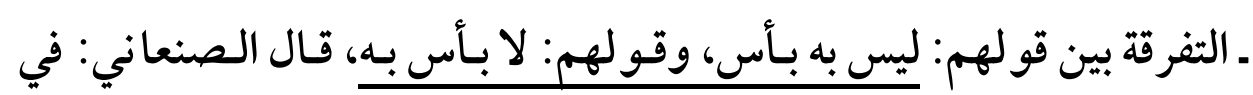

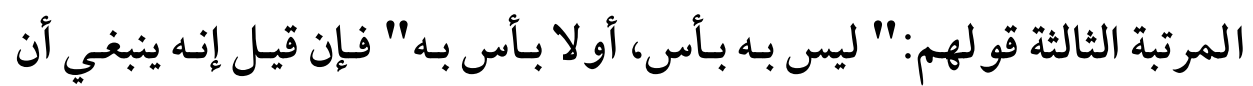

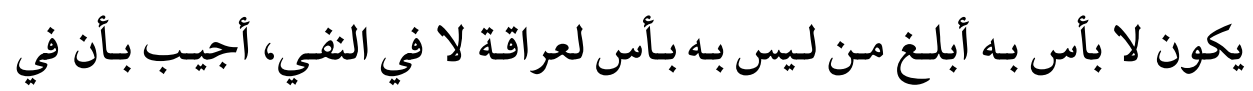

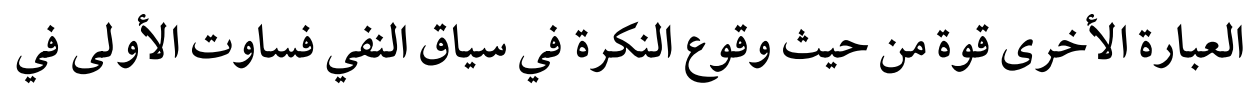
("). الجملة

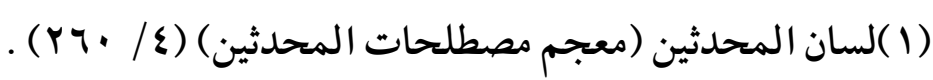

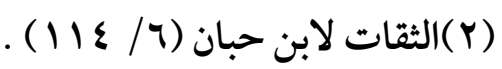

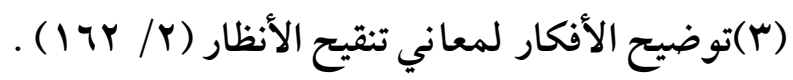


ـ ومنه قولهم: بِخِ، قـال ابن منظور: كلمـة تقال عند تعظيم الإنسان، وعند التعجب من الثيء، وعند المدح والرضا بالشيء، وتكـر رلمبالغـة. (1)، فهي

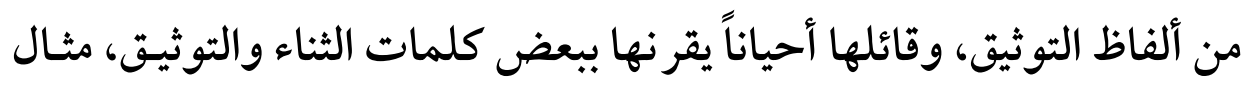

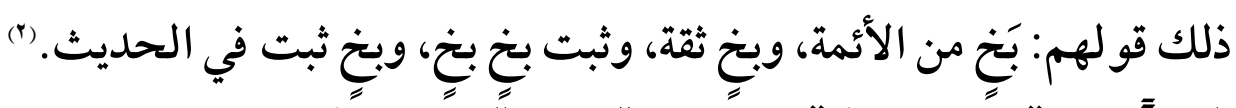

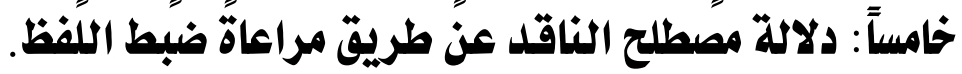

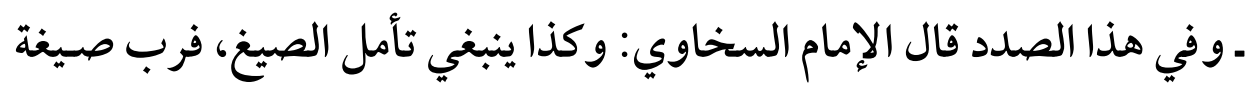

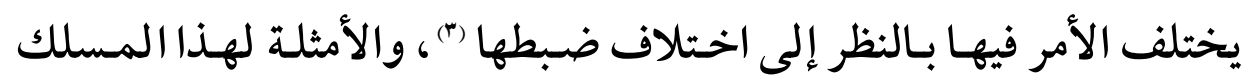

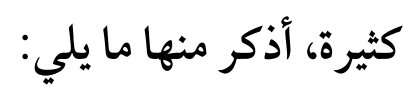
ـ قولهم في الراوي: "على يـدي عـدل" وممـن اشتهر بتجريح الرواة بهـذا.

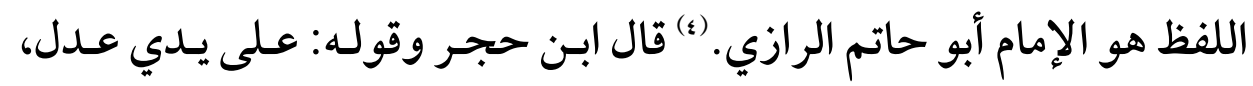

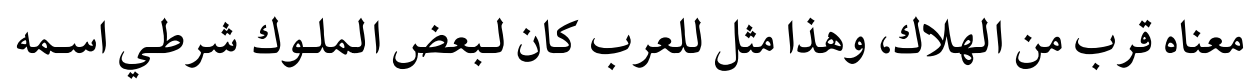

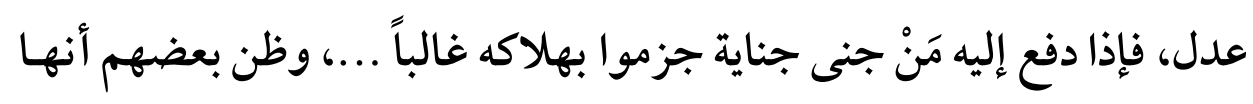

$$
\begin{aligned}
& \text { (1) لسان العرب (ז/ צ) . }
\end{aligned}
$$

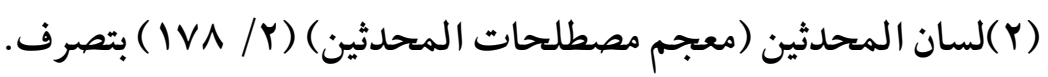

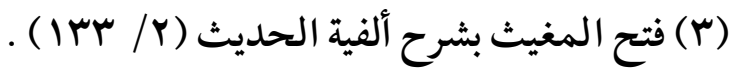

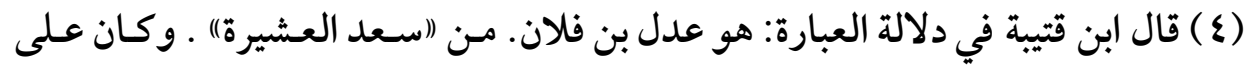

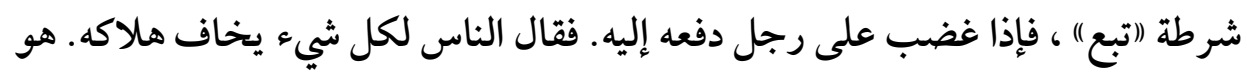

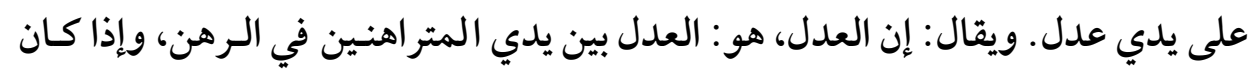

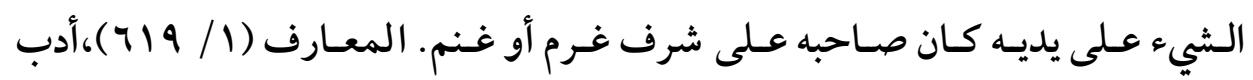
الكاتب = أدب الكتاب لابن قتيبة (ص: بـ هـ ) . 
(rr)

من ألفاظ التوثيق فلم يصب). (1) قلت: ولعل ابن حجر بقوله: وظن بعضهم

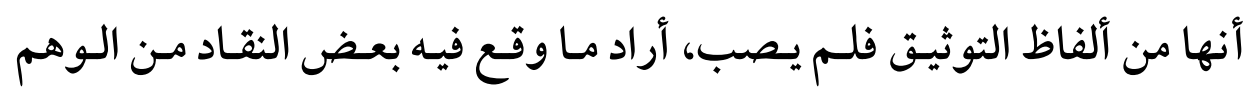
بسبب قراءة العبارة على غير وجهها الصحيح. ـ فقد ذكر السخاوي عن شيخه ابن حجر أن العر اقي كـان ينطق بها هكـا

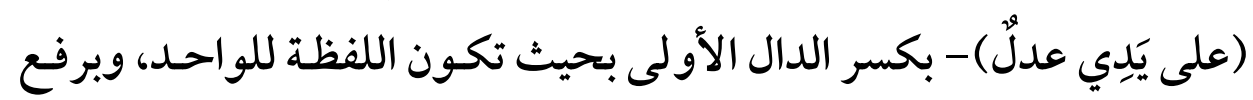
اللام وتنوينها في عـدل - وقـد استشكل الحـافظ ابـ حجر كونها للتوثيق لقول أبي حاتم في تر جمة جبارة بن المغلس: ضعيف الحـديث، وقوله لمـا

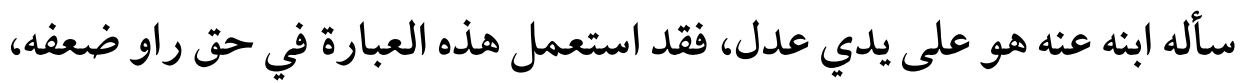
ثم تحقق ابن حجر من كونها للجرح الشديد بعـدوقوفهـ عـلى أصل العبارة عند العرب. (r) ـ و وممن وقع في هـذا الوهم فظن أن هـذه العبـارة للتوثيتق الإمـام الذهبي في تر جمة كل من: محمد بن خالد بن عبد الله الطحان، ويعقوب بـن محمـد بـن عيسى من كتابه الكاشف كما يلي:

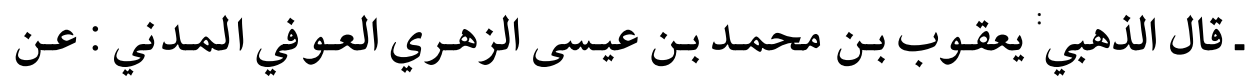
إبر اهيم بن سعد و محمد ابن أخي الزهري ؛ وعنه الفسوي وابسن أبي مَسَرّة ؛

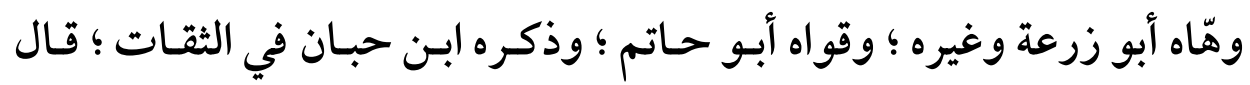
البخاري في الصلح: حدثنا يعقوب حدثنا إبراهيم بن سعد؛ فلعله العوفي ؛ 
(५)

توفي ثلاث عشرة ومائين. (1) ويعقوب هذا قال فيه أبو حاتم لما سأله عنه ابنه عبد الرحمن: هو على يدي عدل (ه)، أدر كته ولم أكتب عنده، فالذهبي عدَّ هـذهـ اللفظة تقويةً.

ـ ومنه قولهم في الراوي: "فلان مود" حيث اختلف في ضبطها:

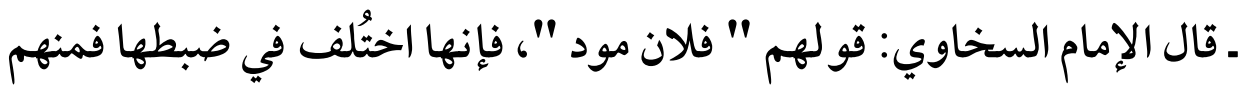

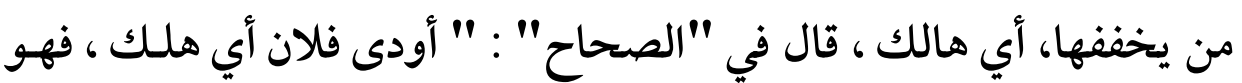

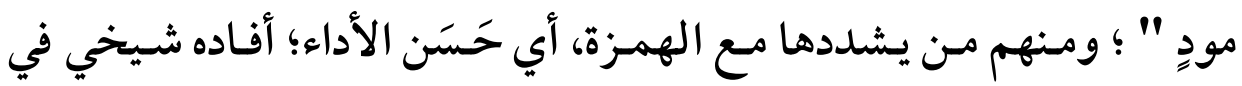

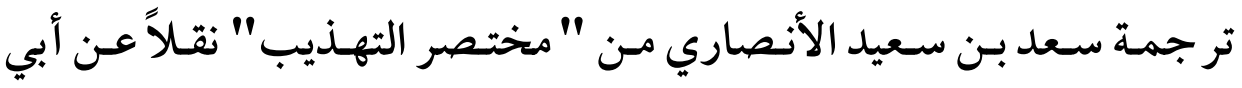
الحسن ابن القطان الفاسي، وكذا أثبت الوجهين كذلك في ضبطها ابن دقيـق

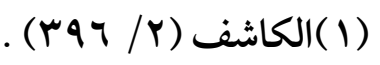

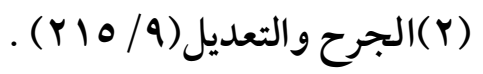

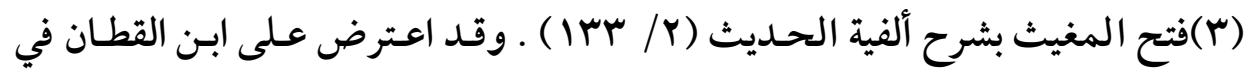

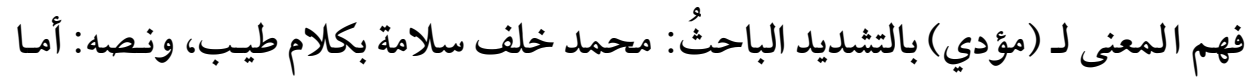

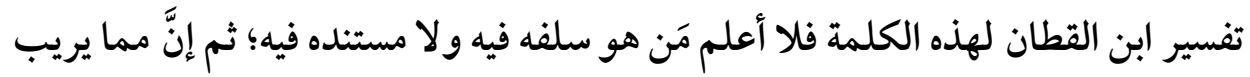

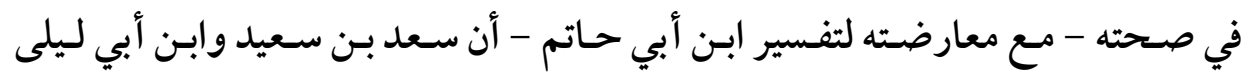

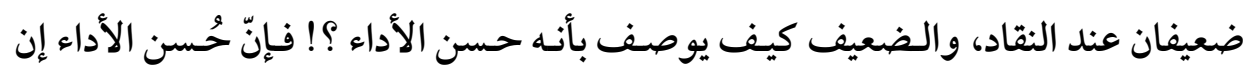

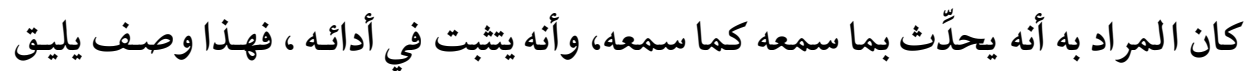

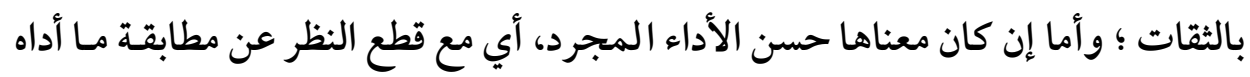

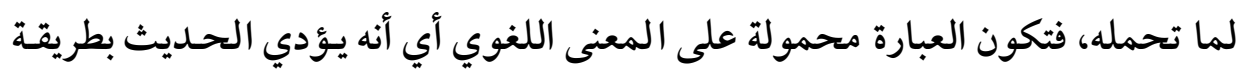

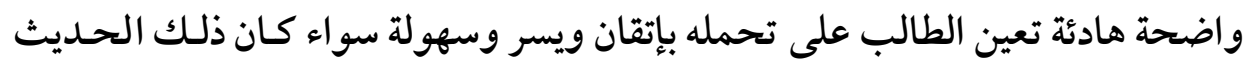


(ro)

سادساً: دلالة مصطلح الناقد في الراوي من خلال استقراء وتتبع ألفاظه.

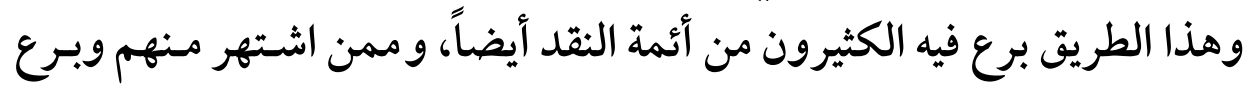

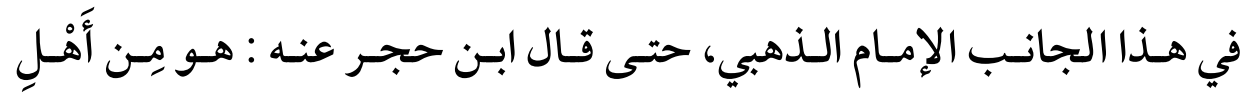

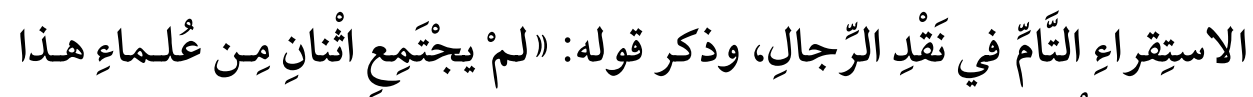

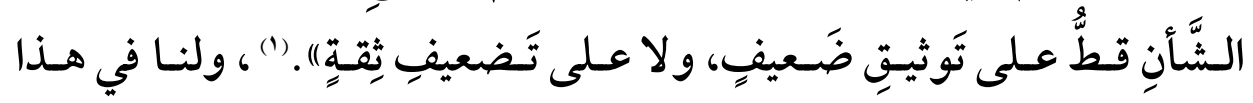
المسلك أمثلة عديدة، منها ما يلي: ـ قال عبد الله بن أحمد: سألت أبي عـن يـونس بـن أبي إسـحاق؟ فقدـال: كـذا

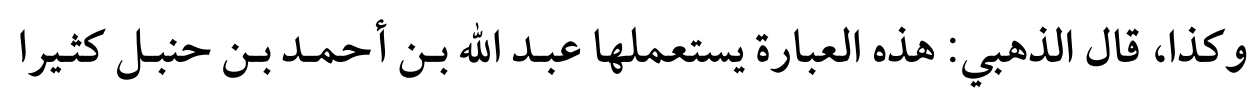

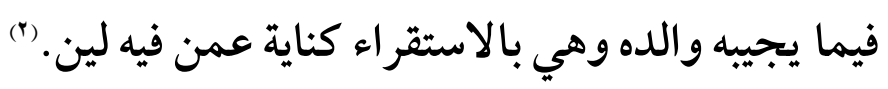

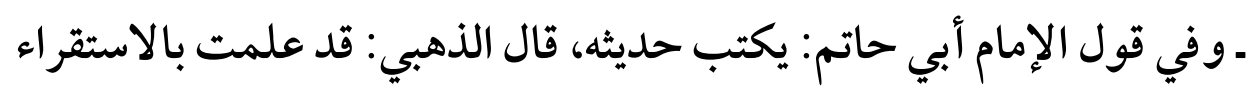

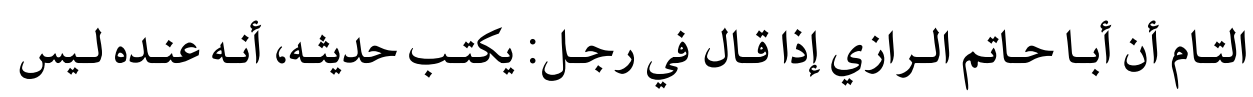

بحجة.

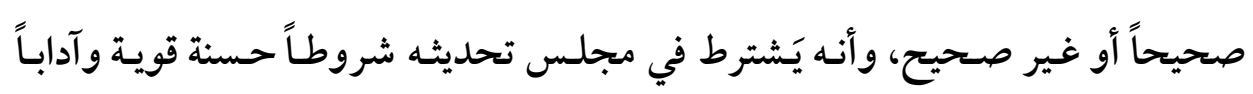

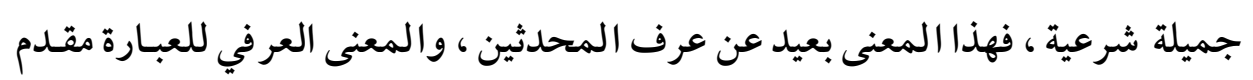

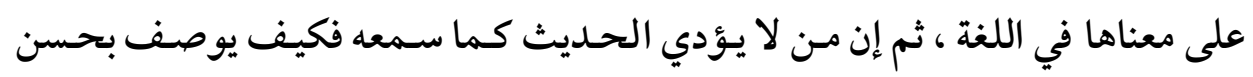

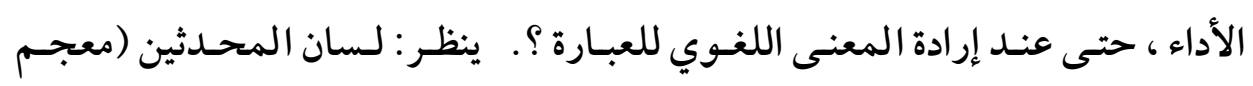

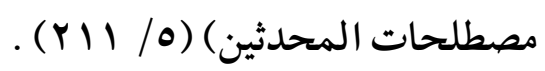

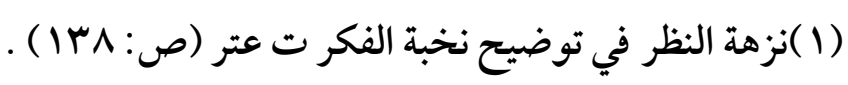

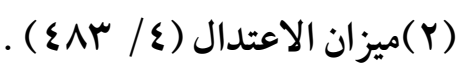

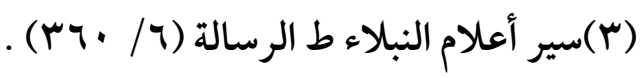


(ry)

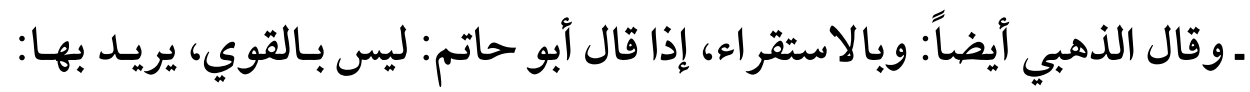
أن هذا الشيخ لم يبلغ درجة القوي الثبت. والبخاري قـد يطلق على الشيخ: ليس بالقوي، ويريد أنه ضعيف. (1)

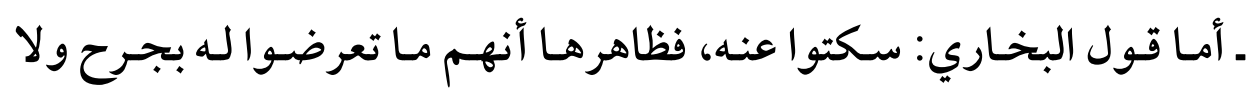
تعديل، قال الذهبي: وعلمنا مقصده بها بالاستقر اء، أنها بمعنى: تركوه. (") -

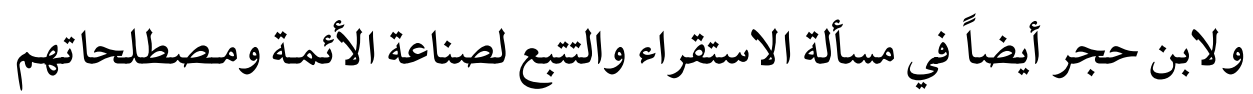
ما صرح به في مواطن عديدة، منها ما يلي: ـ عن قول أحمـد في الراوي: منكـر الحـديث، قـال ابـن حجر : هـذه اللفظة.

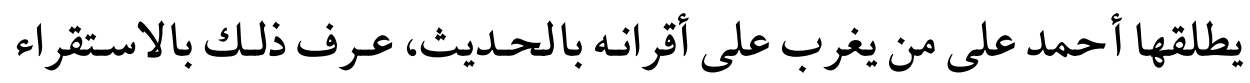

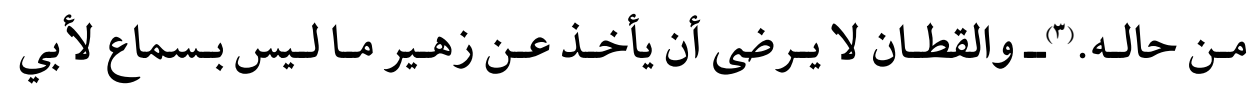

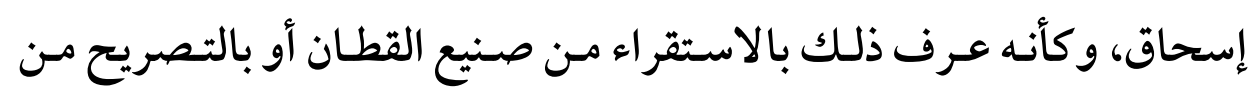
قوله. (8) ـ قوله: أي البخاري، وقال لنا أحمد بن حنبل هـذا فيما قيـل أخــه المصنف عن الإمام أحمد في المذاكرة أو الإجازة، والذي ظهر لي بالاستقر اء أنه إنما

$$
\begin{aligned}
& \text { (1) (1) الموقظة في علم مصطلح الحديث (ص: ( ( ) ) . }
\end{aligned}
$$

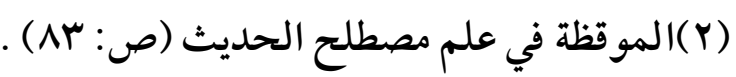

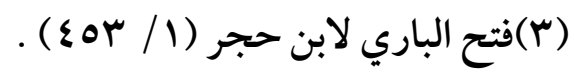

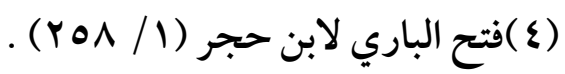


(rV)

استعمل هذه الصيغة في الموقوفات وربما استعملها فيما فيـه قصور ماعن

شرطه. (1)

سابعاً: دلالة مصطلح الناقد في الــراوي بالموازتـة بـين لفظــه وألفــاظ الأئمـة

النقاد.

المقارنة بين أقوال الأئمة النقاد في الراوي عند التعارض أمر ليس سههلاً، في

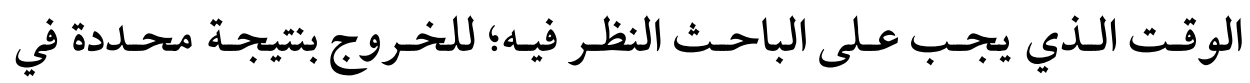
الحكم على الراوي، ومن الأمثلة على هذا المسلك ما يلي:

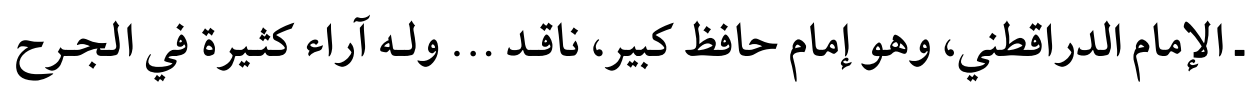
والتعديل، نجدها في الضعفاء والمترو كين له، وفي سؤالات السهمي لـه، وكـذا البرقاني، وفي كتابه السنن، والعلل، والإلزامـات والتبـع، وهـو مـن المعتـلين في الجـرح والتعـديل، وقـــ يتعـارض قولـه مـع غيره، كقولـه في

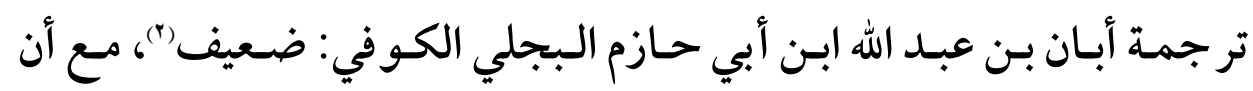

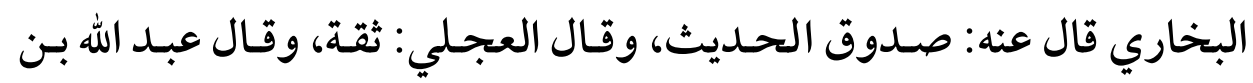

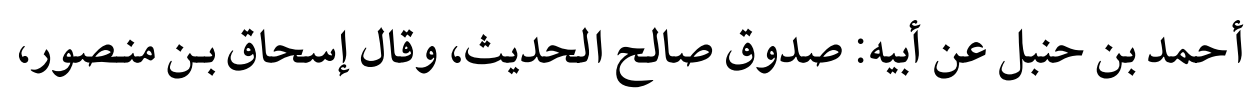

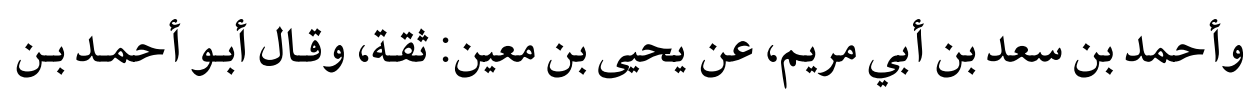

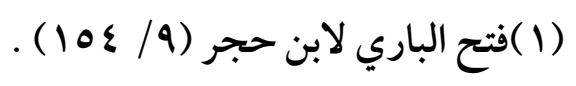

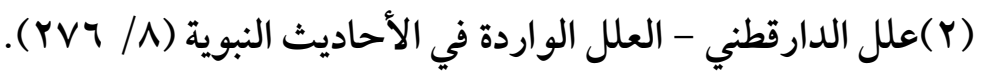


(rA) دلالة المصطلحات الخاصة بين النقاد في تجريح الرواة (دراسة وتحليل)

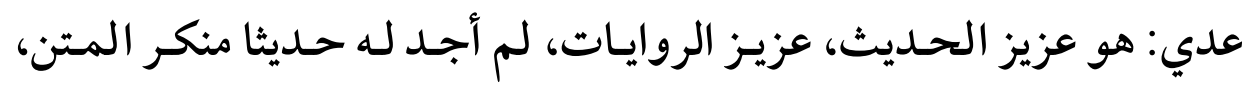

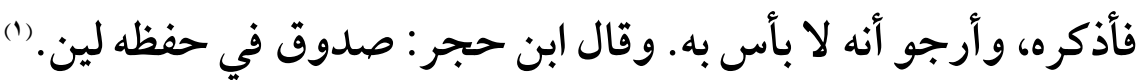
قلت: وفي هذه الحال لابد من مقارنة كلامه مع كلام غيره؛ لنصل إلى الرأي

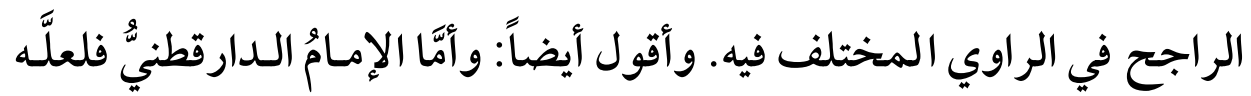

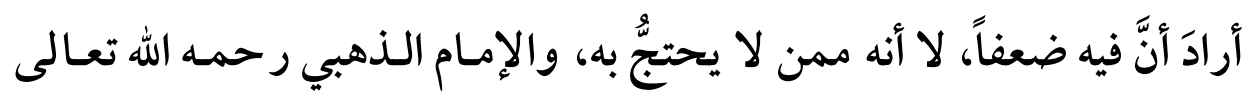

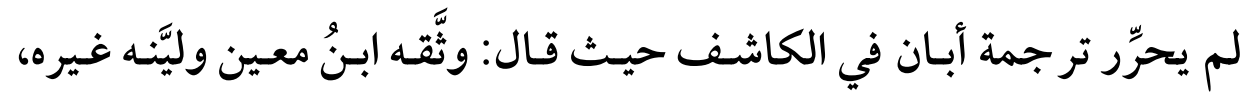
وهذه عادة له في بعض التراجم، لكنه قال في الميزان: حسن الحديث.

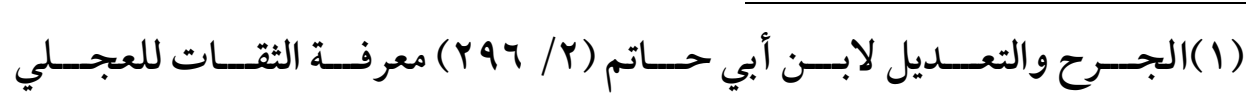

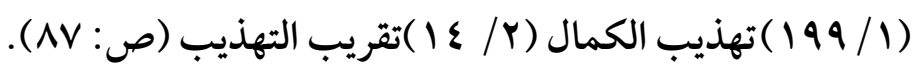


(rq)

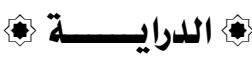

المطلب الثالث: تعريف الجرح لغة واصطلاهًا، و أهميته

في نقد الرواة.

أولاً: الجرح لفة له مصنيان:

ـ قال ابن فـارس:(جـرح) الجـيم والراء والحـاء أصـلان: أحسد هما الكسب،

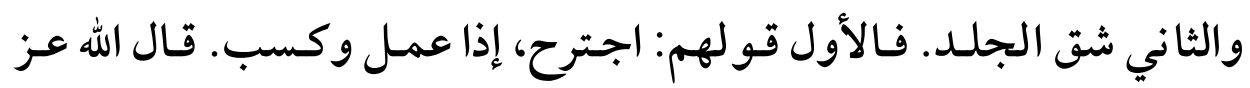

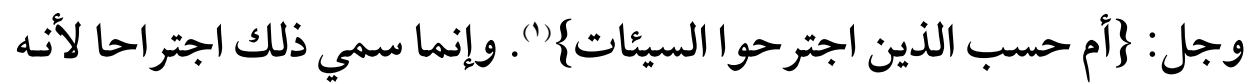
عمل بالجوارح، وهي الأعضاء الكواسـب. والجـوارح مـن الطير والسباع:

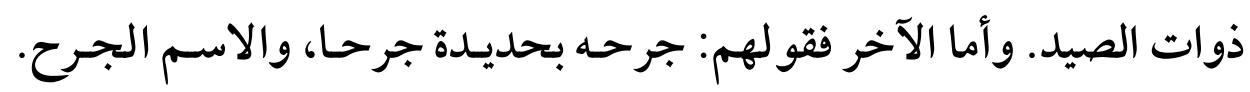

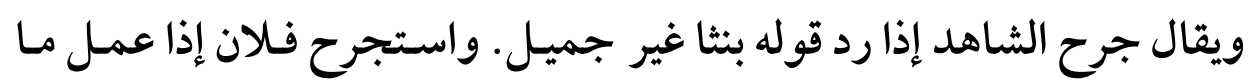

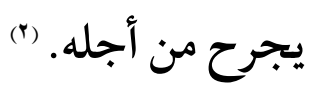

ـ يفهم مما سبق أن لفظ الجرح قد يكون حسياً، إذا كـان في الجـوارح، وقـد

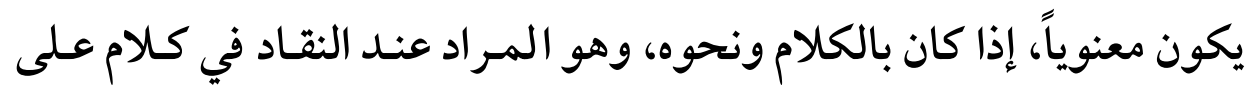

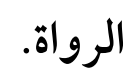

ثانياً: الجرح في الاصطلاح. • جميع التعريفات التي جاءت في ضابط لفظ الجرح كلها ترمي إلى وصف الاحف الر اوي بما يقتضي رد روايته.

(1) (1) الجاثية: اYY].

(Y)مقايس اللغة (1/ / ( ) ؟ ). 


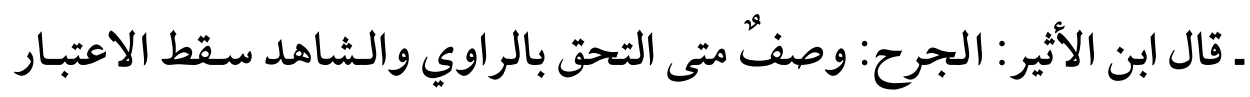

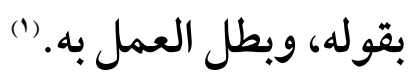
ـ وقيل: رد الحافظ المتقن رواية الراوى لعلة قادحة فيه أو فى روايته من فسق

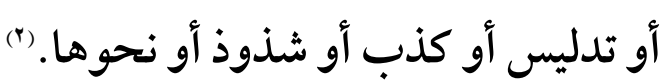
عَدَمَ قُبْولِ رِوَوَيَتِهِه.

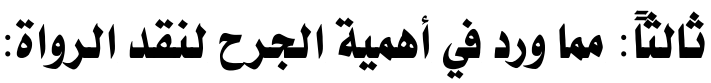

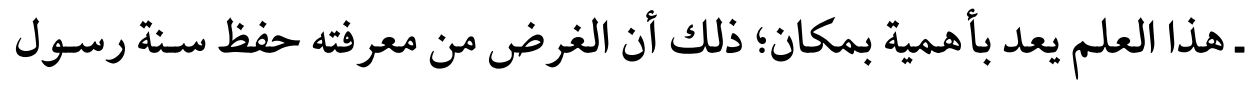

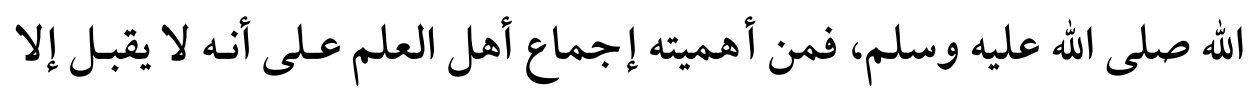
خبر العدل، كما أنه لا تقبل إلا شهادة العدل؛ لذلك كان السؤال عـن المخبـ إنهي

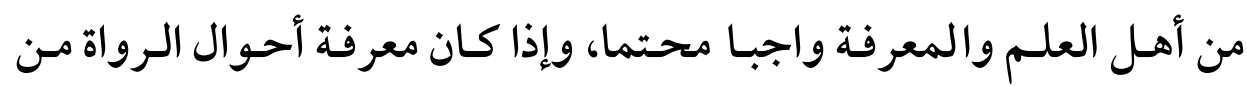

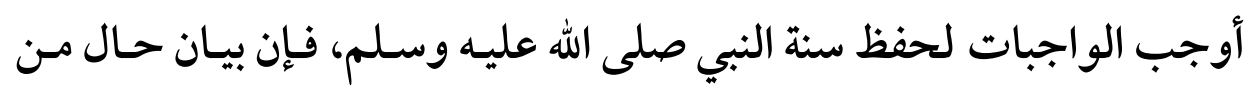
عرف بالضعف والكذب، وكذا من عرف بالضبط والعدالة من ذلك الواجـب

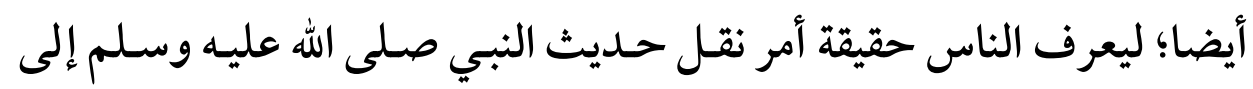

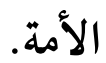

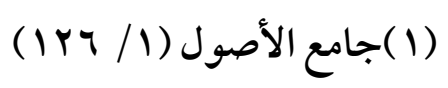

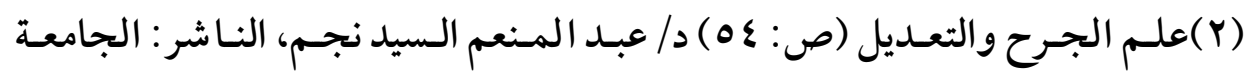

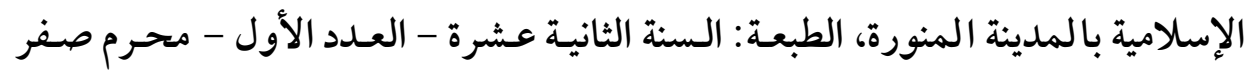

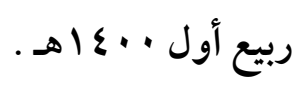


(₹1)

ـ قال أبو داود: سمعت أحمد، وعثمان بن أبي شيبة، والحسن بن علي، وهذا لفظه، كلهم يذكره عن عفان، عن يحيى بن سعيد قال: سألت سفيان الثوري،

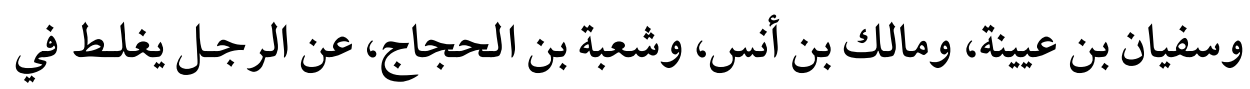

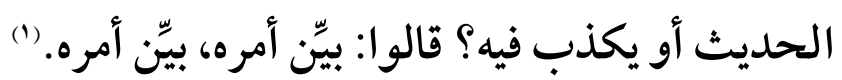

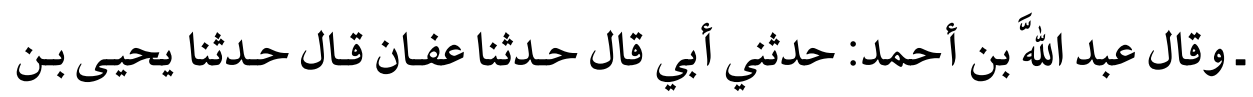

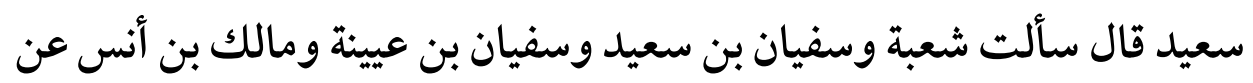

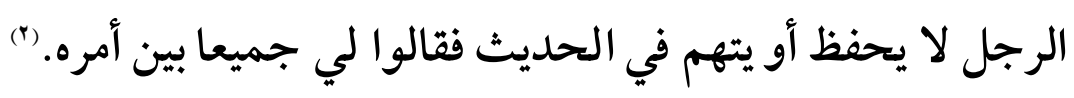

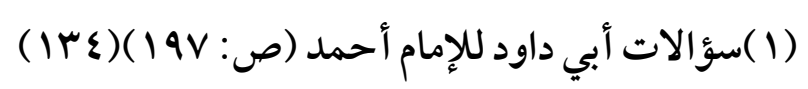

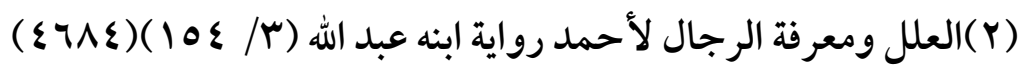




\section{ـ المبحث الثاني: دراسة لدلالة بعض الاصطاصات الخاصة}

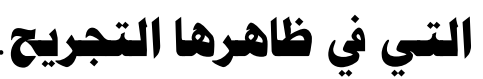

عبارات التجريح من حيث الدلالة ومعرفة المعنى المقصود منها أمر في غاية الأهمية؛ لتقدير مكانة الر اوي بدقة، ووضعه في مكانه، حسب ميزان التهر الجرح إن صح التعبير؛ لتأتي نتيجة الحكم على الراوي والرواية منضبطة وصحيحة، وفق القواعد المصطلح عليها عند المحدثين، وهذه مسألة لابد من تحصيلها لمن يتصدى لدراسة الروايات ونقد الرواة، حيث إن بعض الاصطلاحات في الجرح قد تختلف دلالتها بين الأئمة النقـاد، وقـد يكسون الاختـلاف مـن إمـام لآخـر، بـل ومـن وقـت لآخر عند نفس الإمـام الناقـد، كما أن لبعض النقـاد استعمالات خاصة بهم في التجريح أيضاً، فهي مسألة في غاية الأهمية. والكلام في الرواة يحتـاج إلى ورع تام، وبـر اءة مـن الهوى والميل، وخبرة كاملة بالحديث وعلله ورجاله. ثم نحـن نفتقر إلى تحرير عبـارات التعـديل

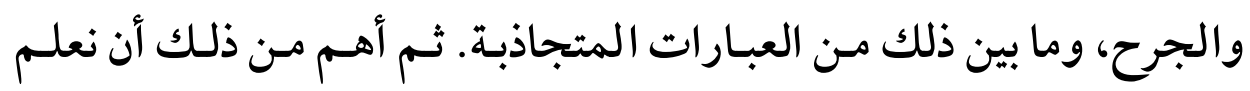
بالاستقر اء التام عرف ذلك الإمام الجهبذ، واصطلاحه، ومقاصـده، بعباراته الكثيرة. (1) إذا التدقيق في معرفة وفهم الدلالة من هذه المصطلحات لابـد منه لكل من يتصدى للحكم على المرويات بصفة عامة، ونقد الرواة بصفة خاصسة، وهـو ما نحاول معالجته في هذا المبحث إن شاء الله تعالى.

$$
\text { (1) (1) الموقظة في علم مصطلح الحديث (ص: (AY). }
$$


ومن خلال مطالعتي لهذه المسألة في كتب أصسول الحـديث، وكتب تراجم الرواة، وبعض البحوث المعـاصرة للمختصين، وجـدت كثيراً مـن عبـارات التجريح عند نقاد الحديث قد اختلف في دلالتها على الرواة، كما أن الأصل في ألفاظ التجريح أن تدل على معنى من شأنه تضعيف رواية الراوي، أو رد

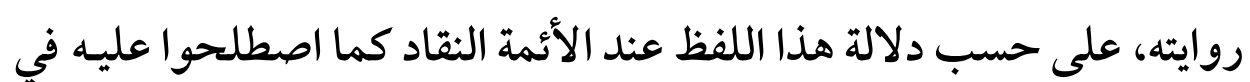

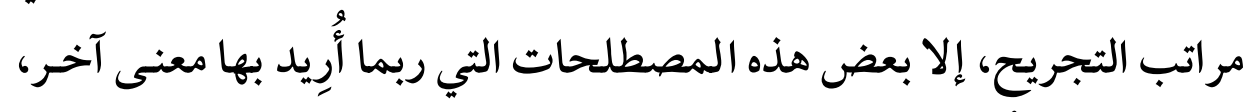

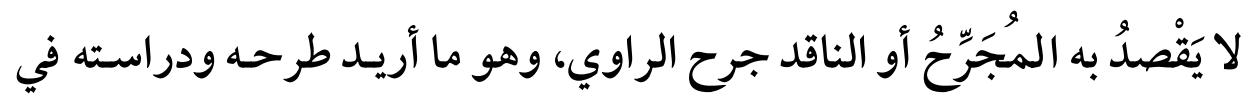
هذا المبحث.

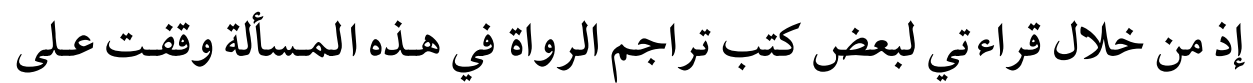

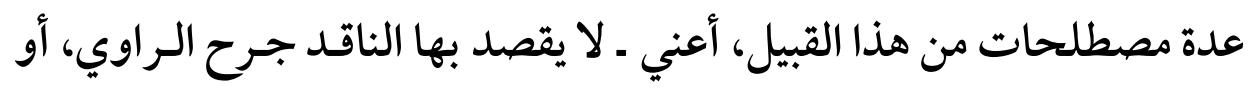

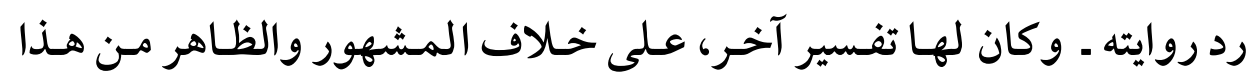

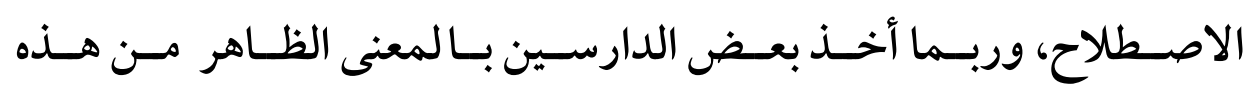
الاصطلاحات، وبادر في الحكم على الر اوي بها دون دراية لدلالة مر اد الناقد من هذا الاصطلاح، ومن ثم تأتي النتيجة في الحكـم على الراوي أو الروايـة بصفة عامة غير صحيحة. قال السخاوي: وكذا ينبغي تأمل الصيغ فرب صيغة يختلف الأمر فيها بالنظر إلى اختلاف ضبطها... (1) وللتيسر على القارئ الكريم نعالج دراستها من خلال المطالب التالية: 
عبـارة(يـسرق الحـديث) مـصطلح مـشهور في تجـريح الـرواة عنـد علـماء

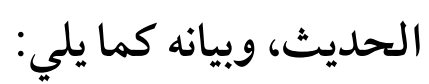

ـ من يسرق الحديث هو من يركب الأسانيد على المتون، قال الذهبي: قال

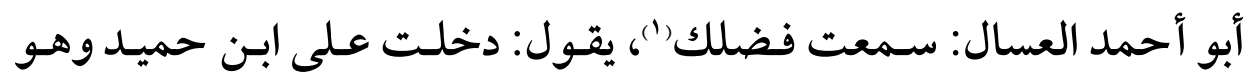
يركب الأسانيد على المتون، قـال الذهبي: قلـت: آفته هـذا الفعـل، وإلا فـما اعتقد فيه أنهّ يضع متناً، وهذا معنى قولهم ("فلان سرق الحديث)" (r). ـ قال السخاوي في المرتبة الثالثة مـن مراتب التجريح عن سرقـة الحـديث:

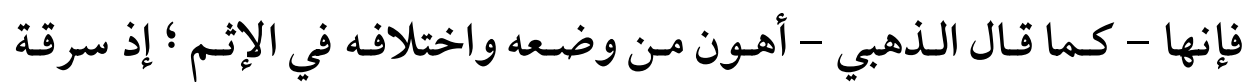
الحديث أن يكون محدث ينفرد بحديث، فيجيء السارق ويـدعي أنه سـمعه أيضا من شيخ ذاك المحدث، أ.هـ ، قال السخاوي: قلت: أو يكسون الحـديث ئديث

(1) الإمام، الحافظ، المحقق، أبو بكر الفضل بن العباس الرازي، صـاحب التصانيف،

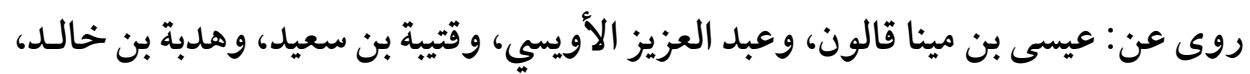

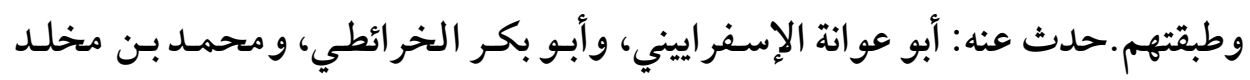

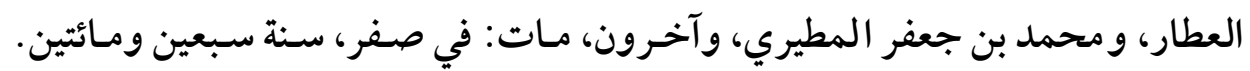

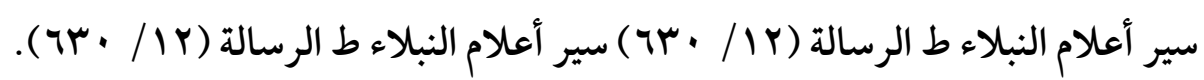

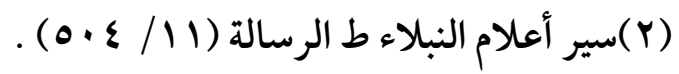


عرف براو، فيضيفه لر او غيره ممن شاركه في طبقته، قال: وليس كذلك مـن

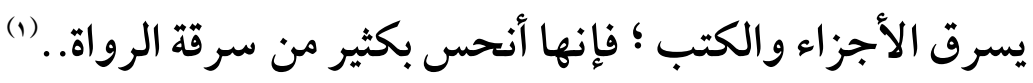

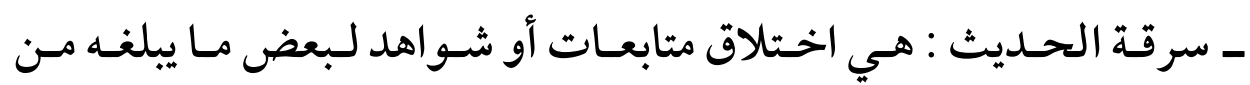
(r) الأحاديث المروية ـ وقيل: المراد بسرقة الحديث: أن يأخذ الر اوي حديث غيره مما لم يسمعه،

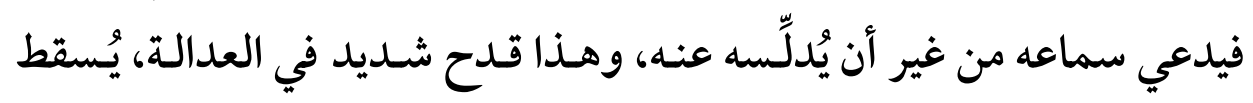
الاعتداد بجميع رواية الموصوف بذلك. (r) نخلص مما سبق أن سرقة الحديث في الأصل جرح. ثانياً: مز الأمثلة:

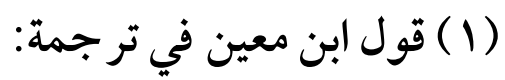

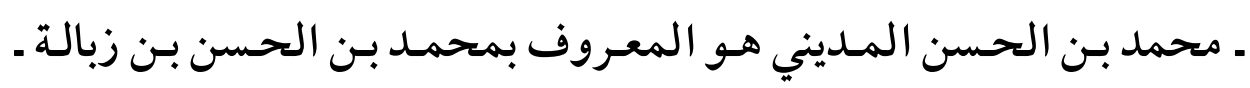
بفتح الزاي و تخفيف الموحدة المخزومي ـ قال هاشم بن مرثد عن ابن معين

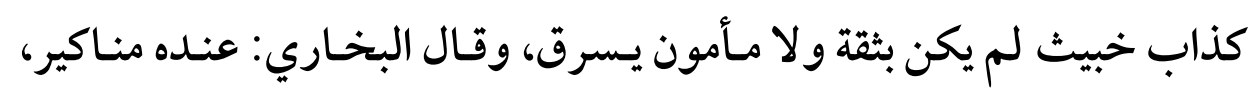

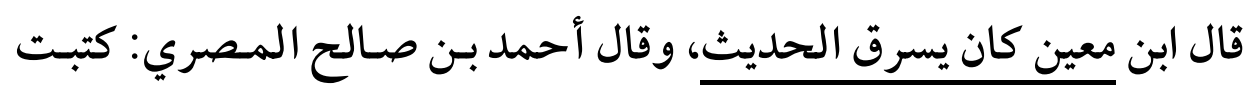

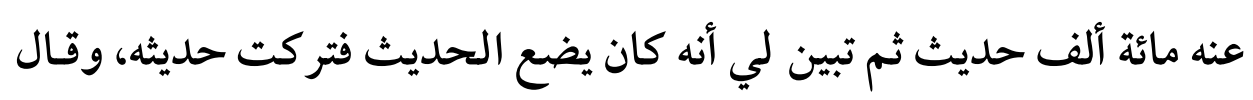

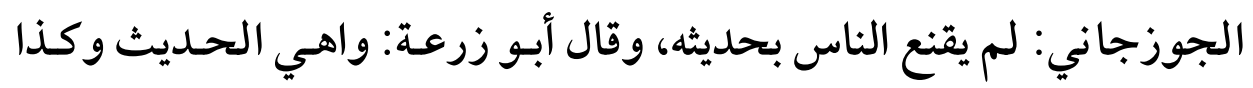

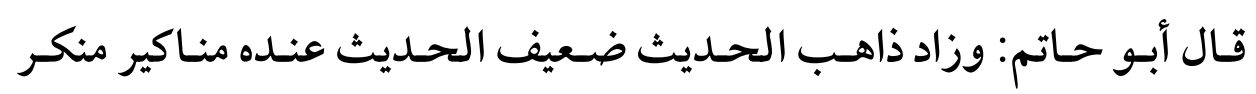

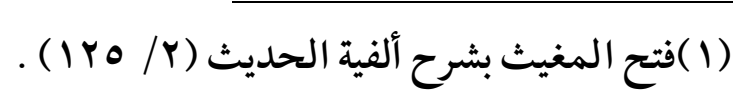

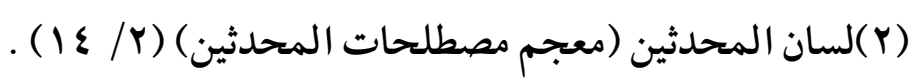

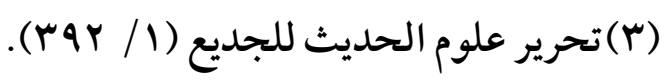




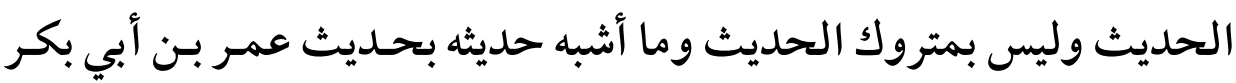

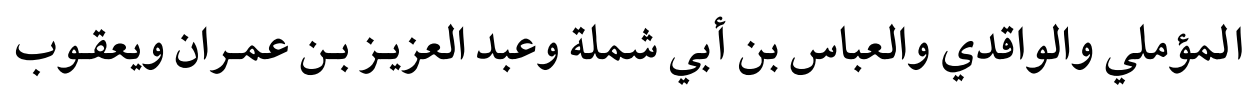
بن محمد وهـم ضـعفاء مشائخ أهـل المدينة، وقـال الآجـري عـن أبي داود:

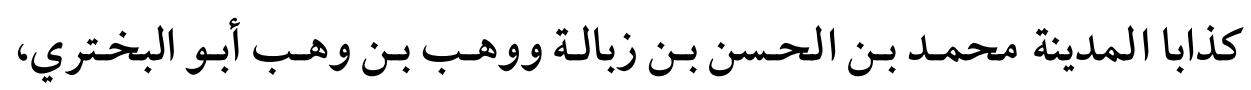

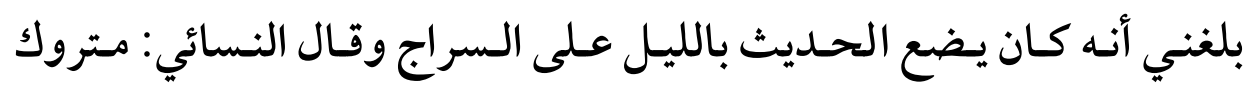
الحديث، وقال في موضع آخر : ليس بثقة ولا يكتب حديثه، وقال ابن حجر : كذبوه من كبار العاشرة مات قبل المائتين. (1) (Y) ( ) قول ابن عدي في ترجمة: ـ سليمان بن أحمد الواسطي: قال البخاري: فيه نظر، و كذّبه يحيى بن معين،

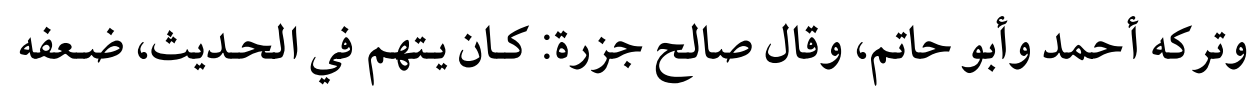

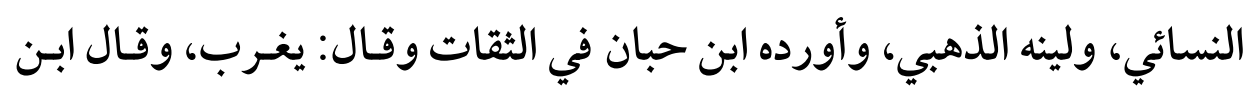

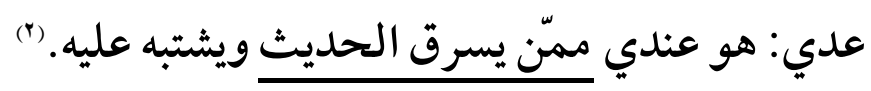

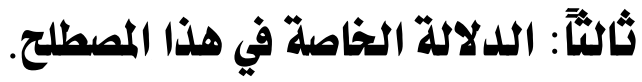

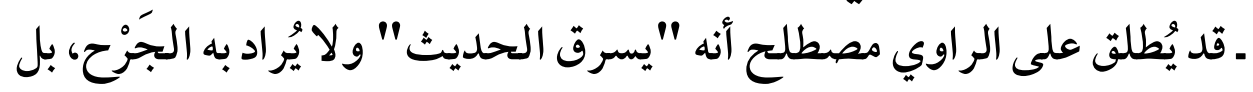

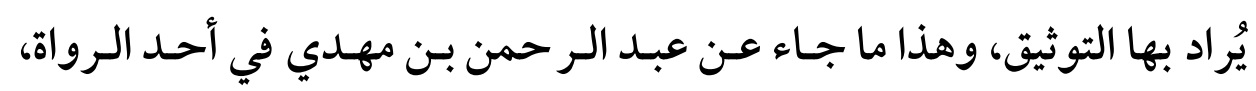

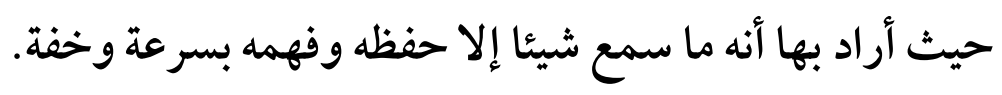

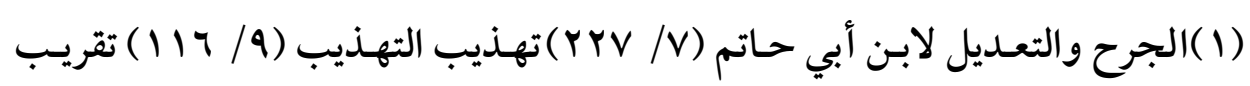
التهذيب (ص: ع § ) .

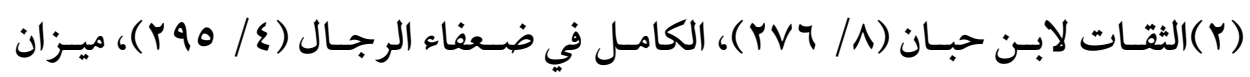

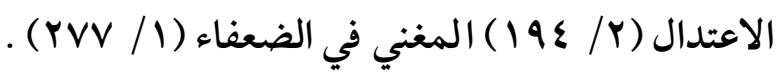


ـ قول ابن مهدي في الحافظ إسرائيل بن يونس، قال عثمان بن أبي شيبة، عن الامتل

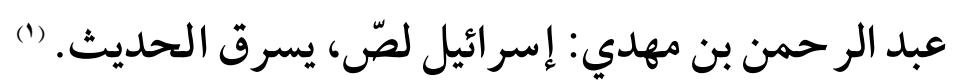

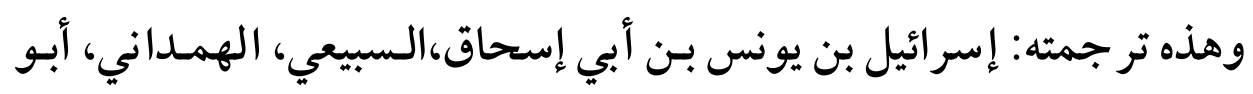

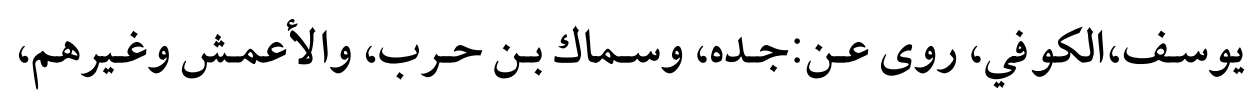
روى عنه: ابنه مهدي، ووكيع ،وأبو نعيم وغيرهم.

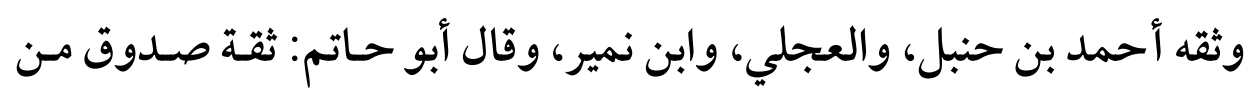
أتقن أصحاب أبي إسحاق، وقال النسائي: ليس به بأس، وذكره ابن وابن حبان في واني

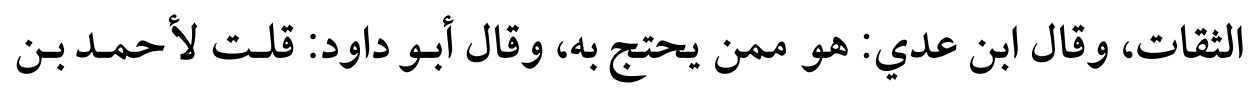

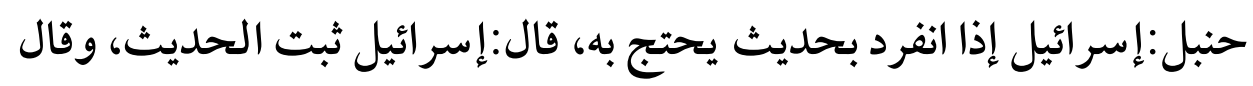

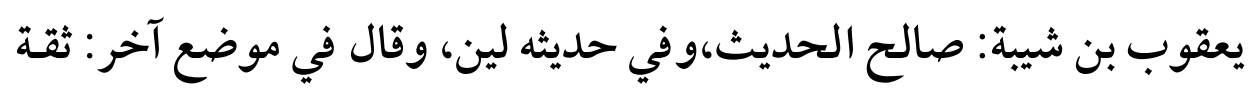

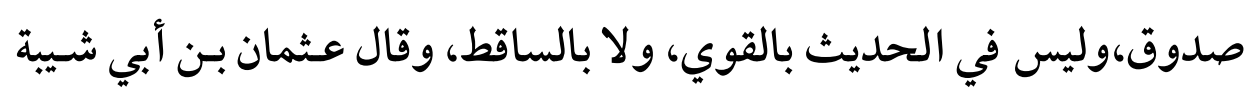

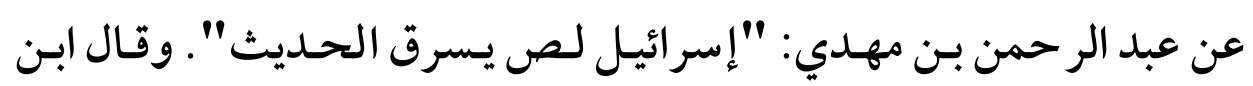

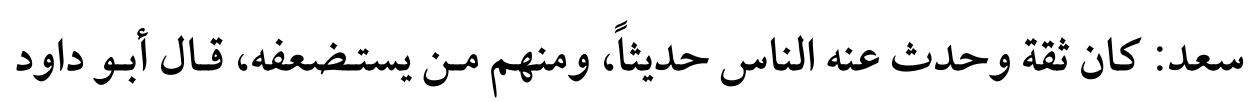

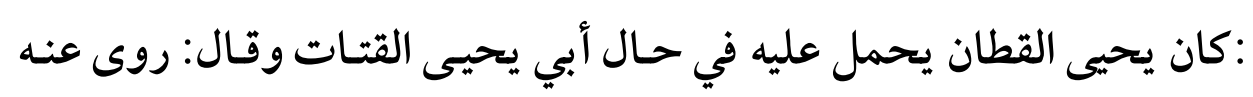
مناكير، وقال ابن أبي خيثمة في تاريخـه قيـل : ليحيـى بـن معين إن إسر ائيل

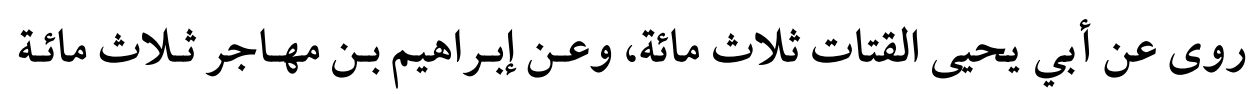

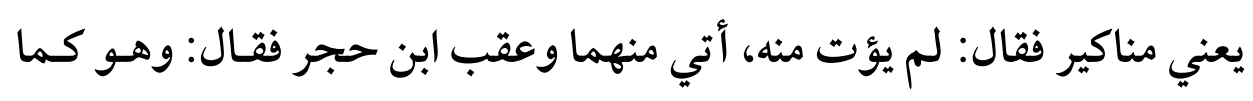
قال ابن معين فتوجه أن كلام يحيى القطان محمول علي أنه أنكر الأحاديـث

(1) تهذيب التهذيب لابن حجر (1/ r r r ). 
$(\varepsilon \wedge)$ دلالة المطلحات الخاصة بين النقاد في تبريح الرواة (دراسة وتحليل)

التي حدثه بها إسرائيل عن أبي يحيى فظن أن النكارة من قبله، وإنما هي مـن

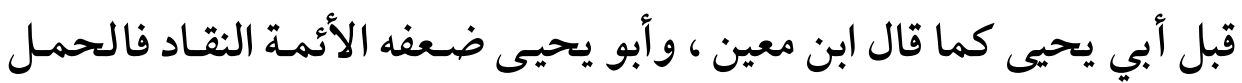

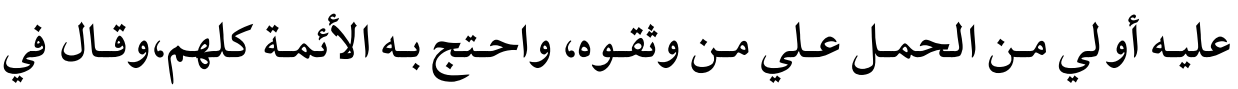
التقريب ثقة تكلم فيه بلا حجة، مات سنة ستين ومئة، وقيل: بعـدها، أخرج لـه (1). الجماعة قلت: أخرج له الجماعة، فهو ثقة، ومن تكلم فيه لم يأت بحجة. أما قول ابـن

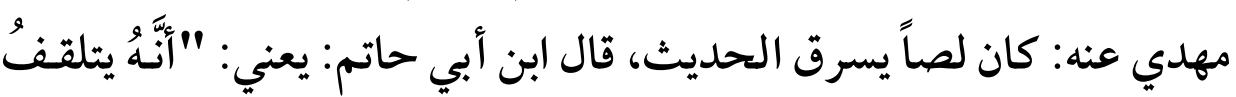

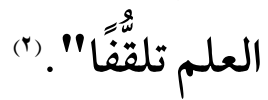
والمعروف عن عبد الرحمن بن مهدي توثيق إسر ائيل والثنـاء عليه؛ لـذلك

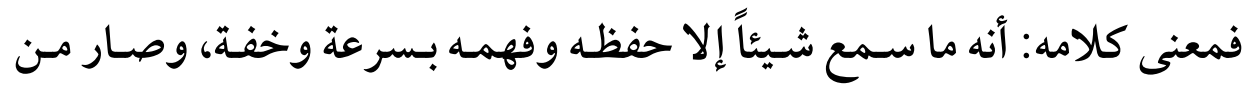

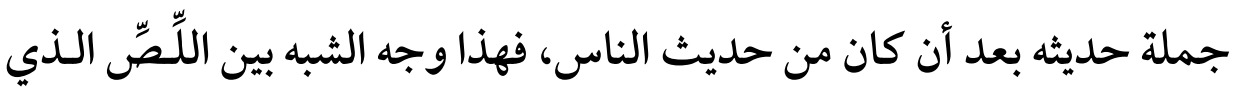
يأخذ حديث الناس بخفة وسرعة، وبين الحافظ الفهم الذي إذا سمع شيئاً لم

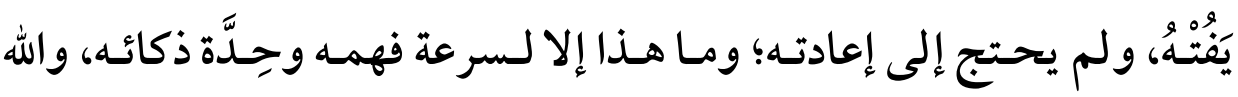
تعالى أعلم (")

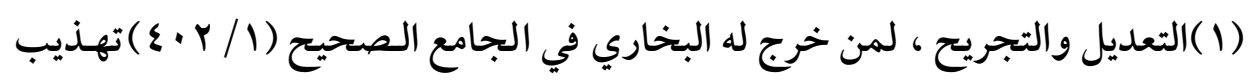

$$
\begin{aligned}
& \text { التهذيب (1/ / / r) تقريب التهذيب (ص: ع +1) . }
\end{aligned}
$$

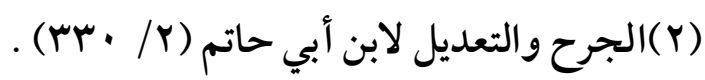

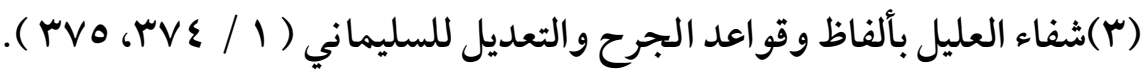




\section{الاطلب الثاني: قواهم في الراوي:(ليس بثقة).}

\section{أولاً: الدلالة المشهورة في هذا المصطلح.}

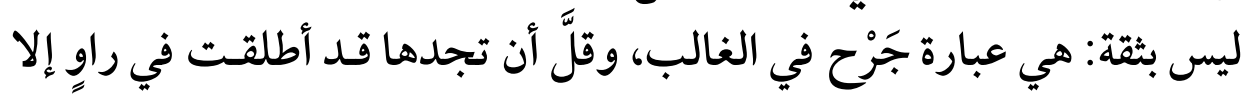

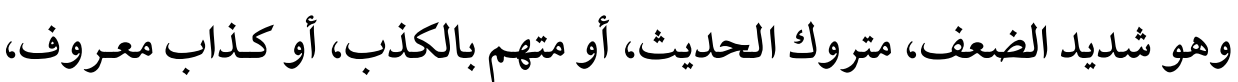

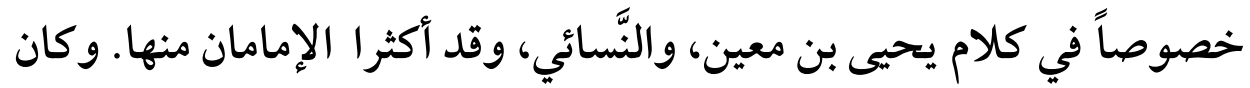
هذا تفسير الحافظ ابن حجر لهذا الاصطلاح في الغالب حيث قال: بل لفظة "ليس بثقة" في الاصطلاح يوجب الضعف الشديد."(1) ثانياً: من الأمثلة. (1 ) قول ابن معين، والنسائي في ترجمة: إبر اهيم بـن الحكـم بـن أبـان. روى

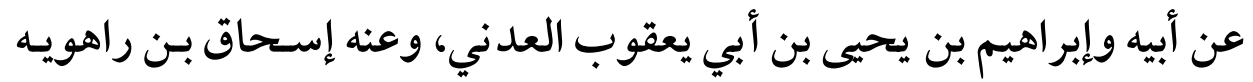
والذهلي وأحمد بن منصور الرمادي وسلمة بن شبيب وغيرهم.

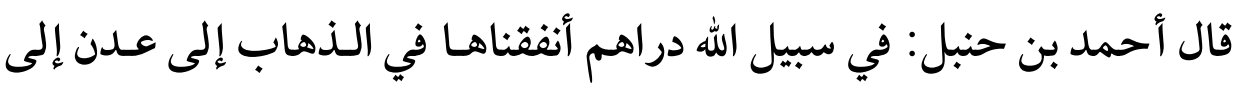

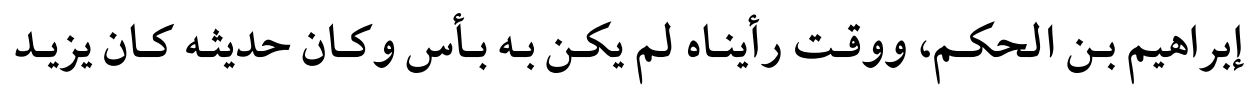
بعدنا، وقال ابن معين: ليس بثقـة، وقال مرة: ضـعيف ليس بـشيء، ومـرة: لا شيء، وقال البخاري: سكتو اعنه، وقال النسائي: ليس بثقة ولا يكتب حديثه، وقـال أبـو زرعـة: ليس بـالقوي وهـو ضسعيف، وقـال الجوزجـاني والازدي: ساقط، وقال محمد بن أسد الخشني: أملى علينا إبراهيم بن الحكم بـن أبـان من كتابه الذي لم نشك أنه سماعه وهو ضعيف عند أصند أصحابنا، فـذكر حسديثا، وقال عباس بن عبد العظيم: كانت هذه الأحاديث في كتبه مرسـلة ليس فيها 
ابن عباس ولا أبو هريرة"، يعني أحاديث أبيه عـن عكرمـة. وقـال ابن عـدي: وبلاؤه ما ذكروه أنه كان يوصل المر اسـيل عـن أبيه وعامـة مـا يرويـه لا يتابع عليه. وقال الدارقطني: ضـعيف، قـال الآجري سـألت أبـا داود عنه فقـال: لا أحدث عنه، وذكره الفسوي في باب من يرغب عن الرواية عنهم، وقال أيضا:

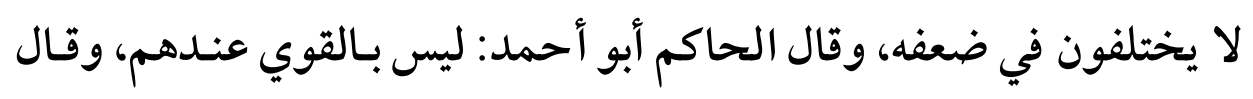

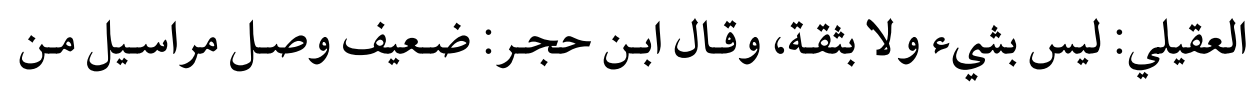
التاسعة." (1) ـ قلت: متفق على تضعيفه، والملاحظ أن عبـارة ليس بثقة جـاءت عندل ابن معين والنسائي والعقيلي؛ لتعني أنه ضعيف، كما أنها وردت ابن معين وقال:

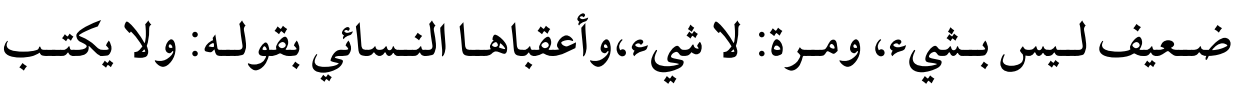

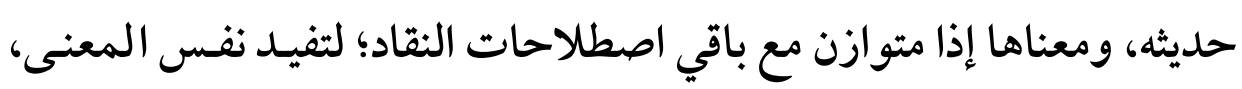
وهذا المعنى هو الغالب من هذا الاصطلاح.

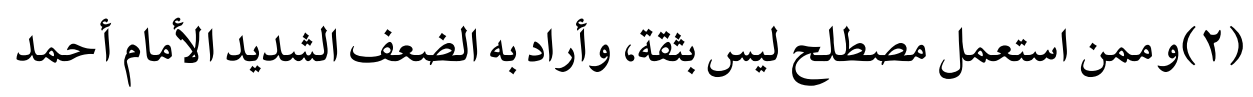
بن حنبل، وذلك في ترجمة: خالد بن عمرو بن محمد بـن عبد الله بـن سعيد

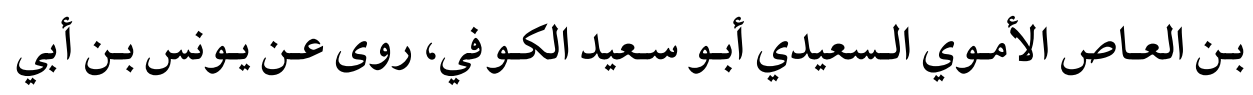

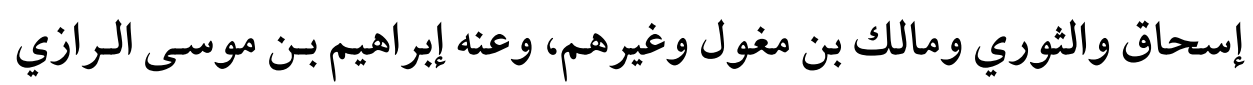
والحسن بن علي الخلال وشهاب بن عباد وغيرهم.

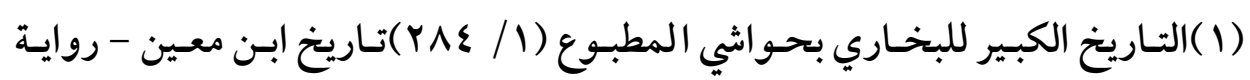

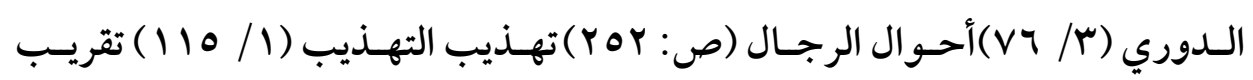

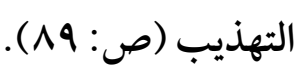


(01)

قال أحمد بن سيار عن أحمد بـن حنبـل: منكر الحـديث، وققال عبد الله بـن

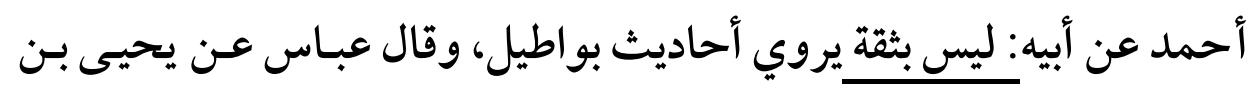

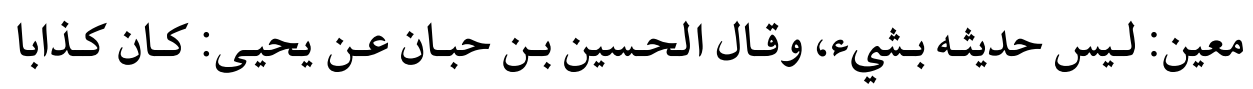

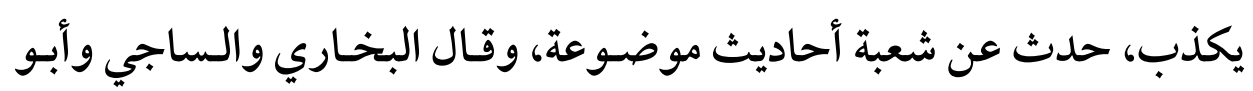

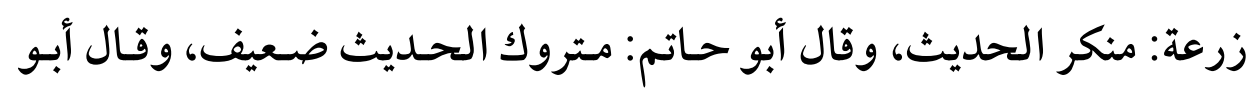
داود: ليس بشيء، وقال النسائي: ليس بثقة، وقال صالح بن محمد البغـدادي:

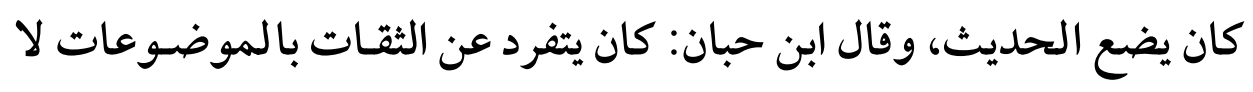

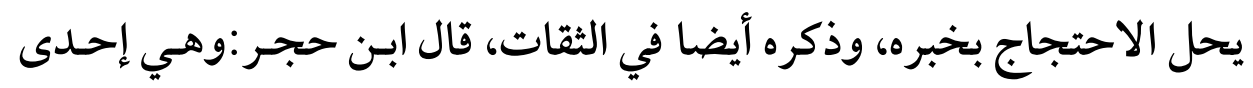
غفلاته، وقال ابـن عـدي: روى عـن الليـث وغيره أحاديـث منـاكير وأورد لـه

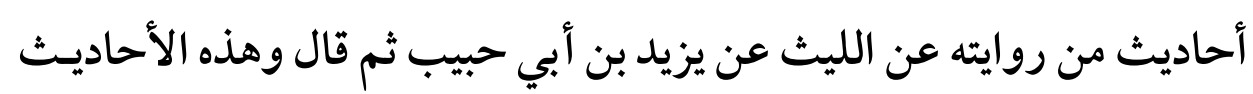

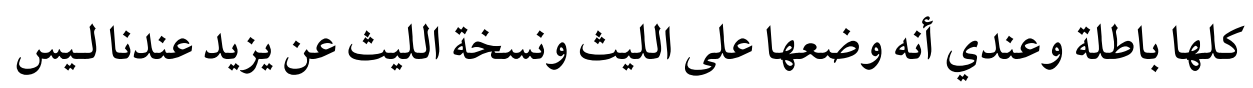

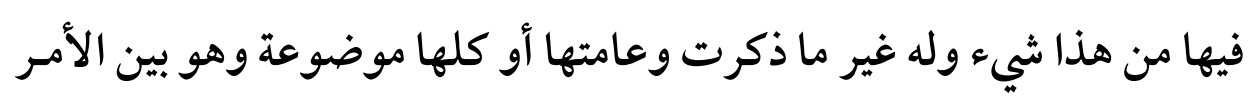

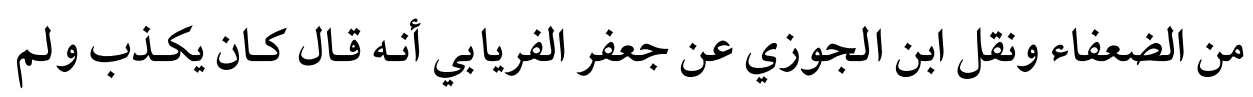

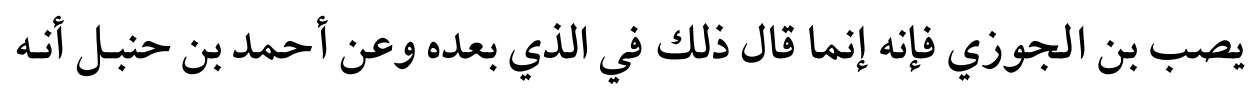

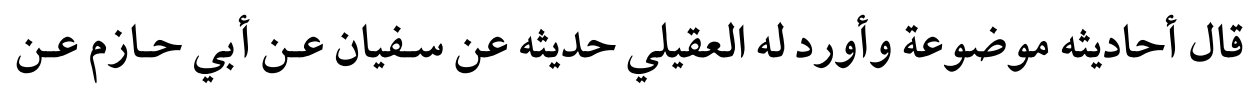

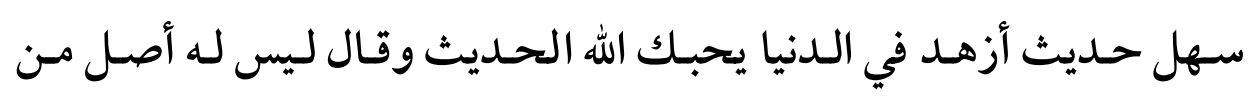
حديث. الثوري وقال العجلي ضعيف كتبنا عنه. (1)

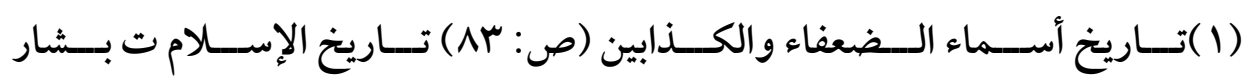

$$
\begin{aligned}
& \text { ( (7/0) تهذيب التهذيب (r/ (1.9) . }
\end{aligned}
$$


لكن ليس ذلك بإطلاق، بل ربما تُطلق عبارة (ليس بثقة) على الراوي، ويُّر اد ادله

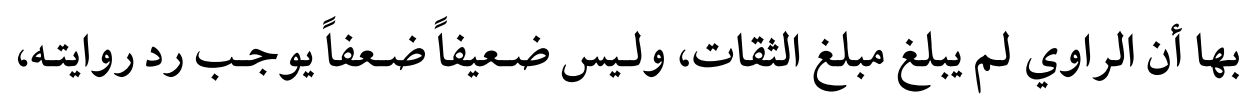

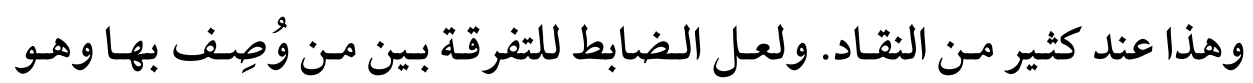

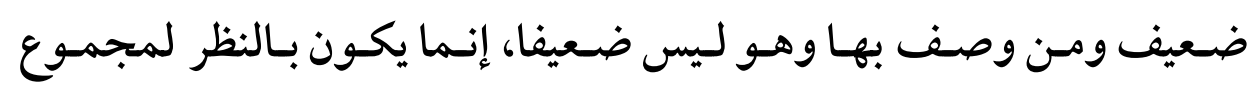

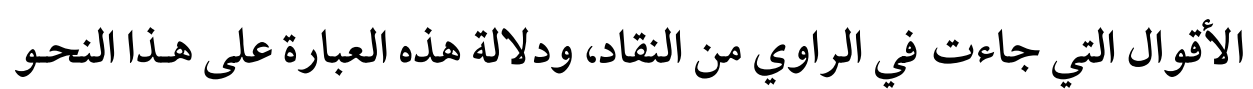

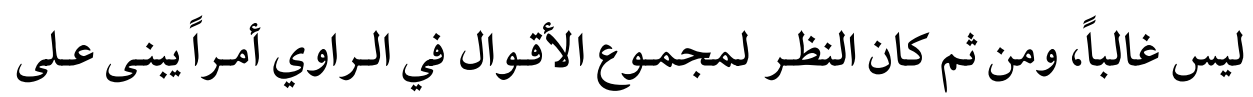

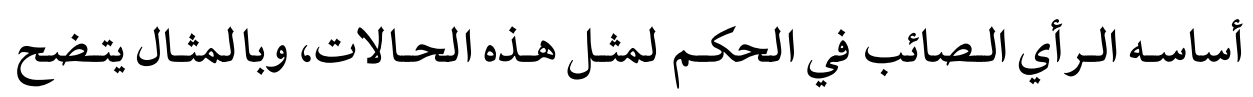

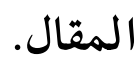

\section{رابعاً: من الأمثلة.}

(1) قـول ابـن معسين والنسائي في تر جمـة: يـونس بـن خبـاب ـ بمعجمــة

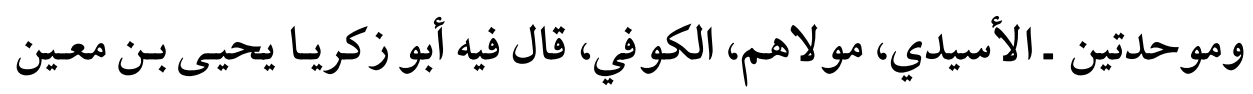

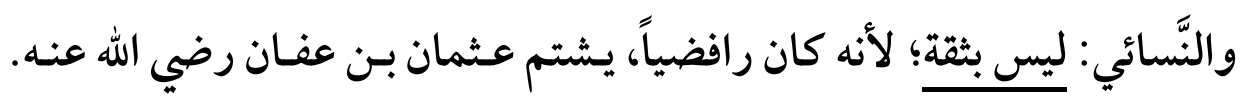

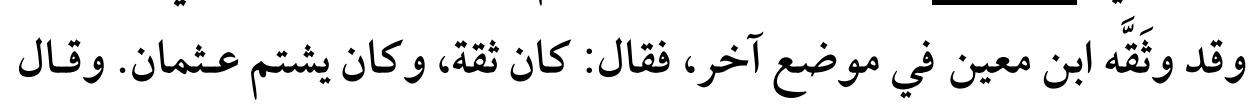

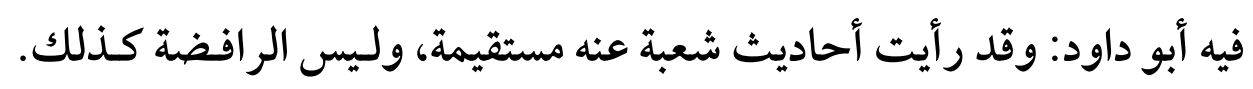
وقال الساجي: صدوق في الحديث، تكلموا فيه من جهة رأيه السوء. وقال وقال

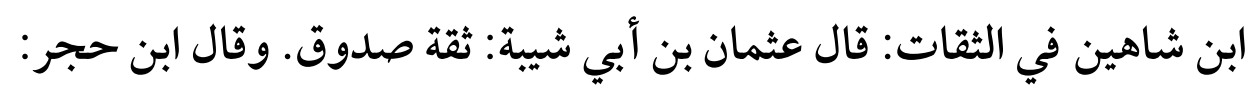
صدوق يخطىء ورمي بالرفض، من السادسة. (1)

(1) تهذيب التهذيب (11 / I \& ) تقريب التهذيب (ص: rاT) . 
(Y) قول مالك بن أنس: قال العجلي: حدثنا أبو جعفر الدارمي. حـدثنا بشر

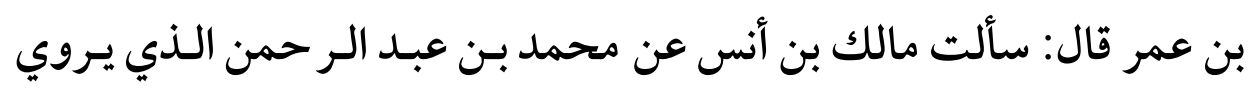

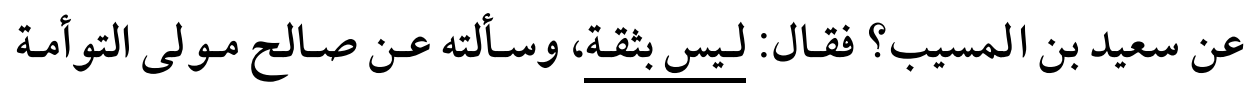

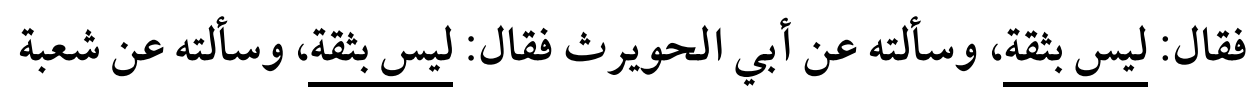

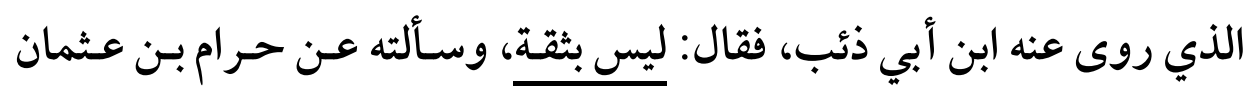

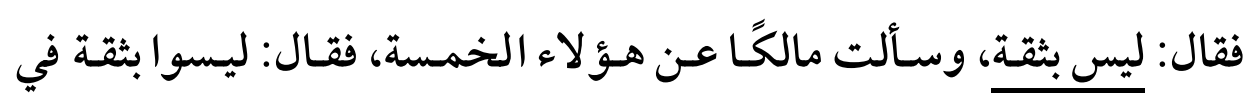
حديثهم. (1) ـ قلت: وهؤلاء الخمسة ليسو ا بضعفاء، ولم يثبت فيهم ما يترك حسدثيهم مـن أجله، ودرجتهم لا تنزل عن درجة الصدوق، أو على الأقل يعتبر بهم.

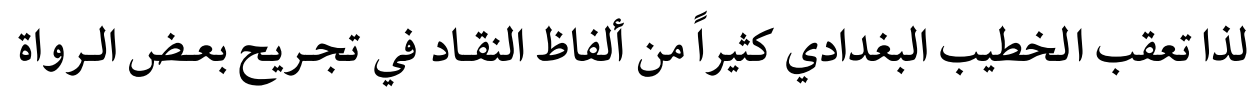

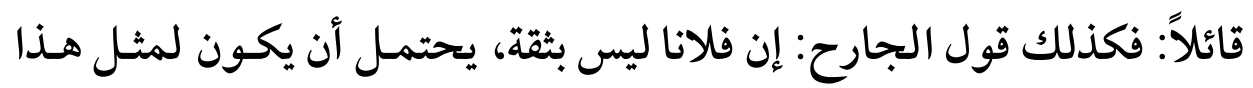

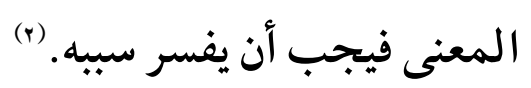

وقوله: يجب أن يفسر سببه، يعني تحرير معنى الاصطلاح في دائرة أقول

$$
\text { الآخرين في نفس الراوي. }
$$

كما تَعَقَّب ابن القطان الفـاسي قـول مالك في شعبة مـولى ابـن عبـاس فقـال:

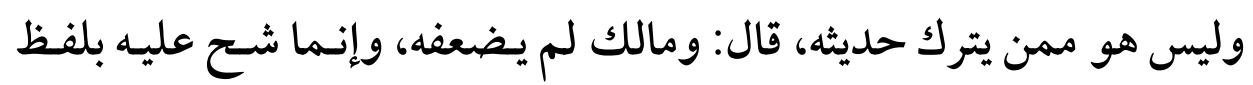

(1) (1) الثقات للعجلي ط الباز (ص: · r ) .

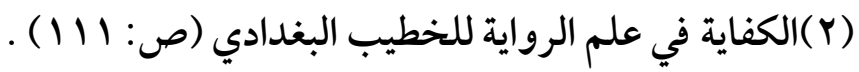

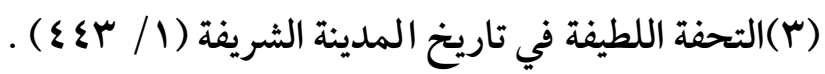




\section{أولاً: الدلالة المشهورة في هذا المصطلح.}

كلمة لشيطان: إما من (شاط) بمعنى هلك، أو من (شطن) بمعنى بعـا (المهد، وهـو المحرق في الدنيا والآخرة والعصي الآبي الممتلىئ شرا ومكرا، أو المتمادي في الطغيان الممتـد إلى العصيان، وله في القـر آن صففات مذمومـة وأسـماء

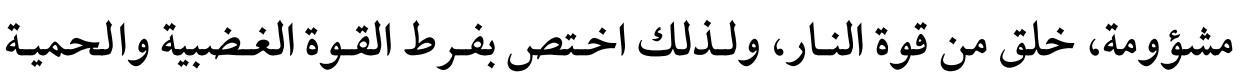
الذميمة فامتنع من السجود لآدم عليه السلام، وإغواؤه إنما يؤثر في مـن كـان

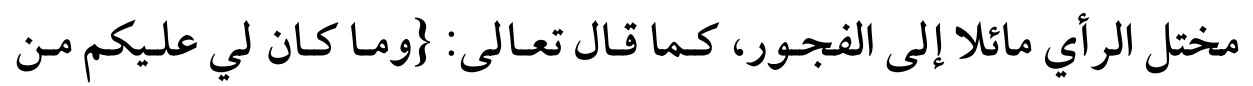

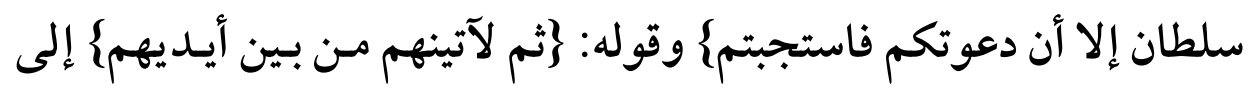

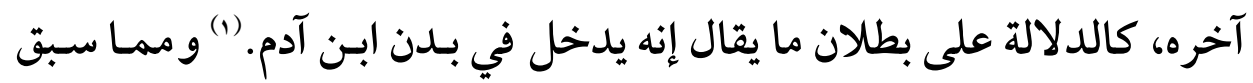
يفهم منه: لو أن راوياً وصف بهذه اللفظة دل على جرحه. ثانياً: ومن الأمثلة.

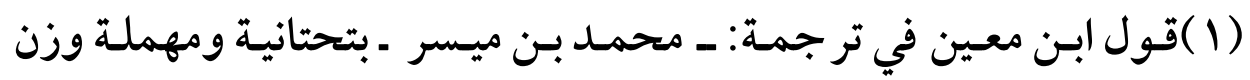

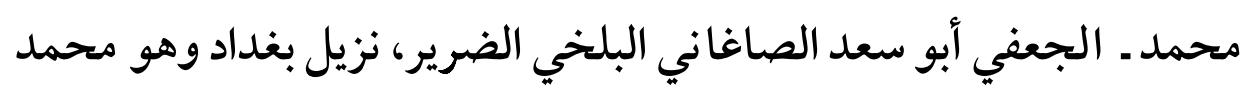

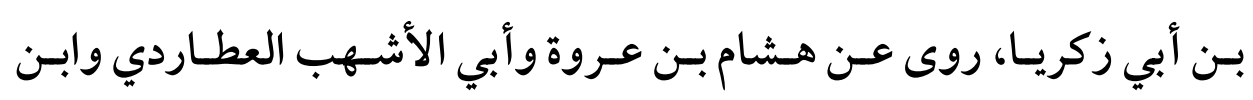

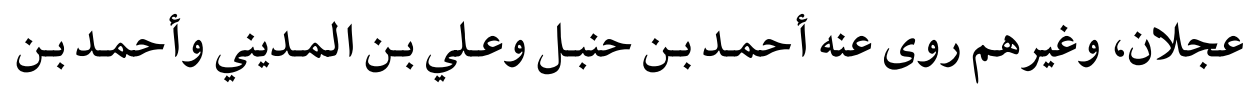
منيع وآخرون. قال أبو داود عن أحمد: صدوق ولكـن كـان مرجئـا، قلت كتبـت عنه؟ قـال: نعم، وقال معاوية بن صالح عن ابن معين: ضعيف، وقال الدوري عن ابن

$$
\text { (1) (1) (صليات (ص: •ـه) . }
$$


معين: أبو سعد الصغاني محمد بن ميسر كان مكفوفا و كان جهميا وليس هو

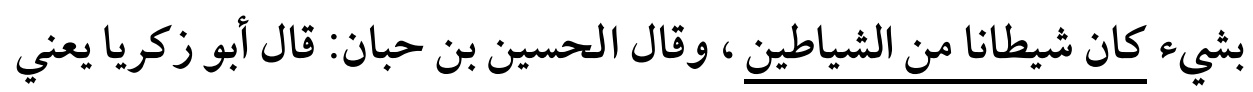

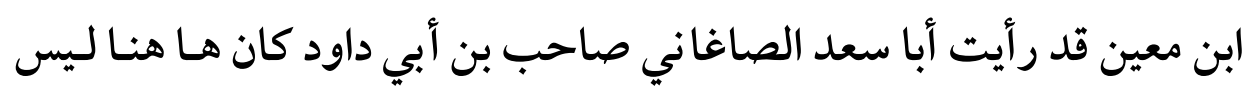

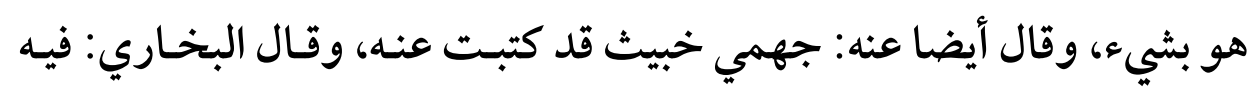
اضطراب، وقال مرة: هو متروك الحديث، وقال في موضع آخر ليس بثقة ولا

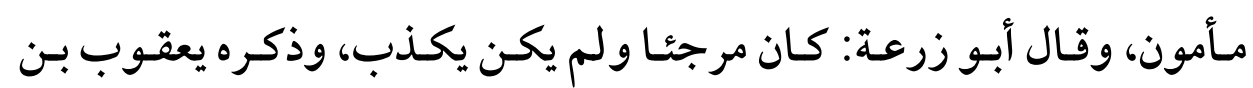

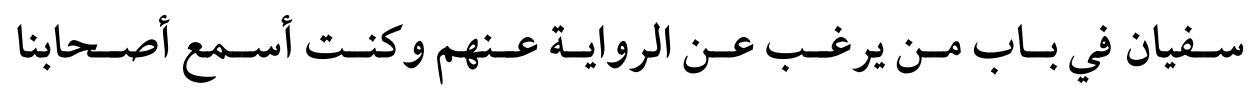

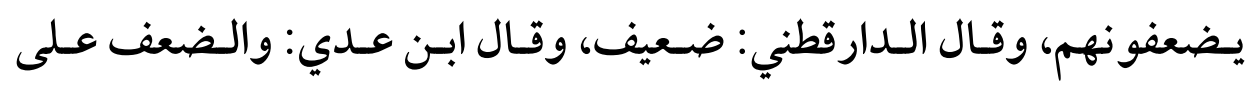

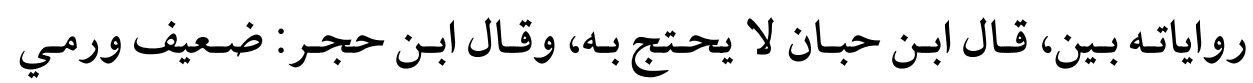
بالإرجاء من التاسعة. (1) (Y) قول ابن عدي: قال إبراهيم بن الأصفهاني أبو بكر: ثلاثة كذابين أبو بكر

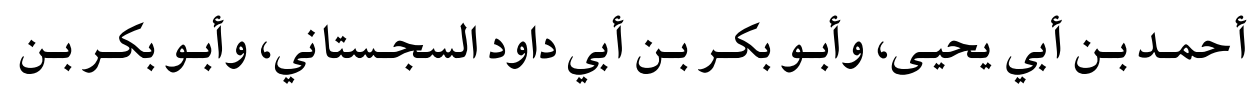

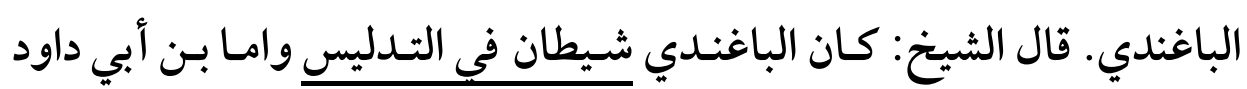
فإن أباه كان كذبه قال ابن صاعد يكفينا ما قال أبوه فيه. (")

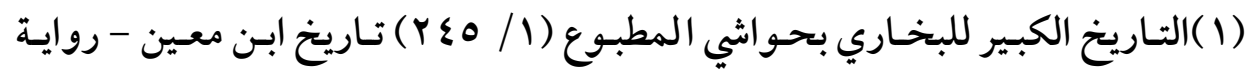

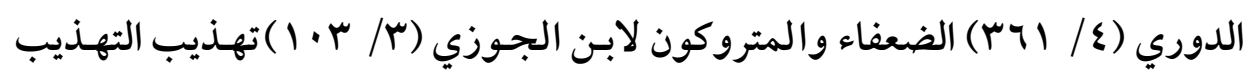

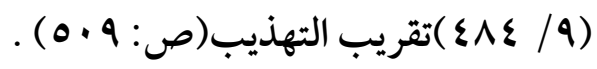

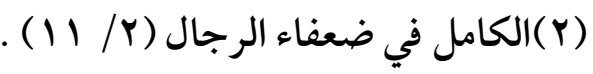




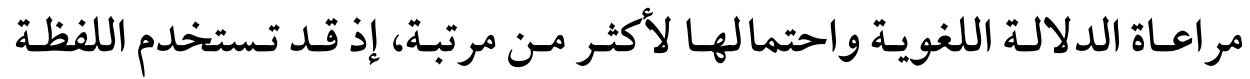
بمعناها اللغوي، أو بأسلوب عربي مجازي، وقد يتبادر إلى الذهن أن إطلاق

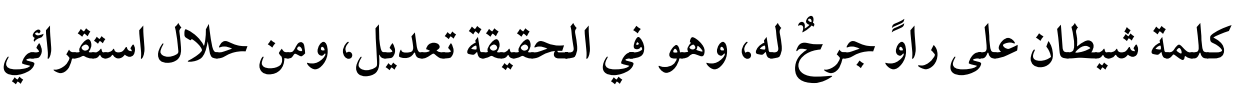
لهذه اللفظة (شيطان) في كتب التراجم وجدت أن أحد النقاد قد وسمى راويـاً بهذا اللفظ وأراد به خلاف ما هو غير متبـادر مـن ظـاهر اللفظ، حيـث أراد بـه سرعة الحفظ وقوة الضبط ، شديد الإتقان. رابعاً: ومن الأمثلة.

(1) قول ابن مهدي في تر جمة: يحيى بن سعيد بن فروخ، الإمام الكبير، أمير

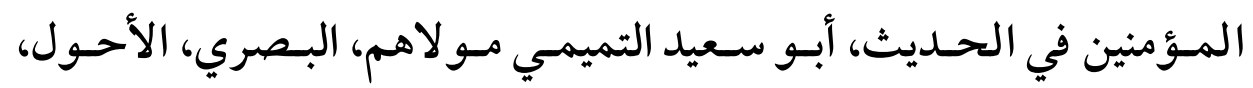
القطان، الحـافظ. ولـد في أول سـنة عشرين ومائة، سـمع: سـليمان التيمي، وهشام بن عروة، وعطاء بن السائب ، وغيرهم، روى عنه: سفيان، وشعبة،

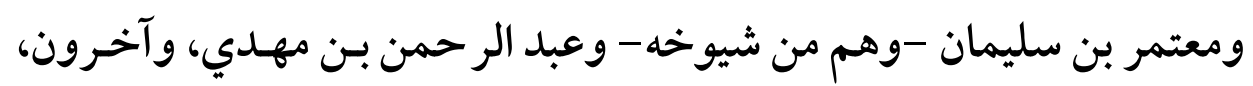

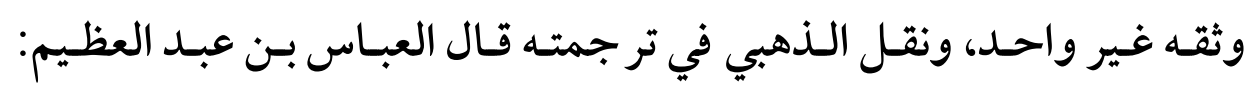
سمعت ابن مهدي يقول: لما قدم الثوري البصرة، قال يا عبد الرحمن! جئني

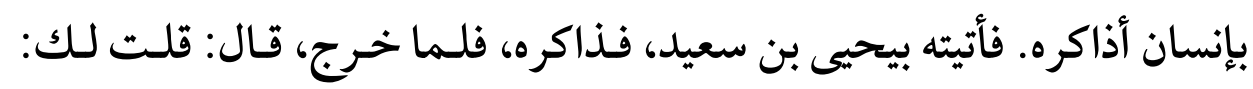

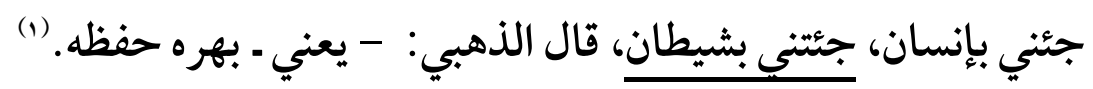

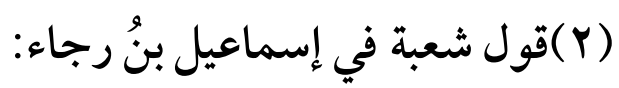

(1) سير أعلام النبلاءط الرسالة (9 / IV) . 
(ov)

每

ـ قال ابن أبي حاتم : قال أبي كان شعبة يقول إسماعيل بنُ رجاء كأنه شيطان

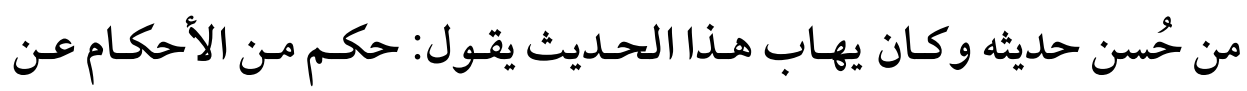

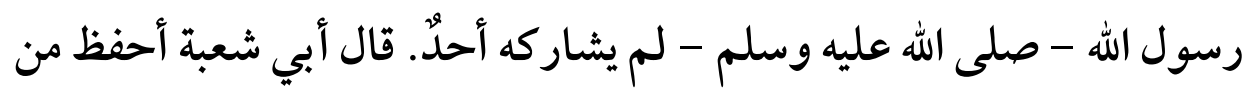
(1) كُلِّهم ـ وقال أبـو داود: سـمت أحمـد يقول: أبـو عقيل الثقفي، يعني الذي روى

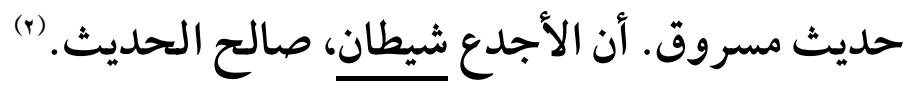

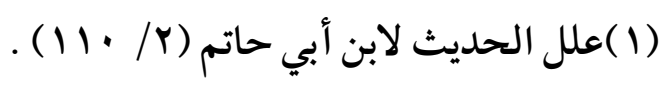

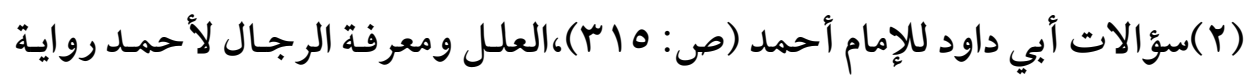
ابنه عبد الله (1/ ـ ـ 1) . 
$(० \wedge)$

\section{الاطلب الرابع: قولهم في الراوي: (لا شيs).}

\section{أولاً: الدلالة المشهورة في هذا المصطلح.}

اصطلاح (لا شيء) كثيراً مـا يستعمله النقاد في ألفـاظ التجريح الغير مبينة

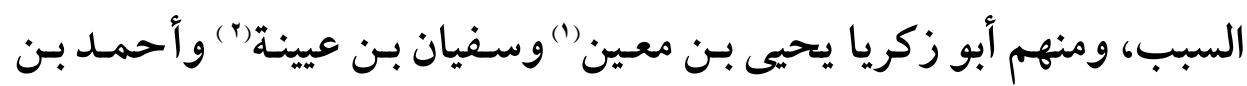

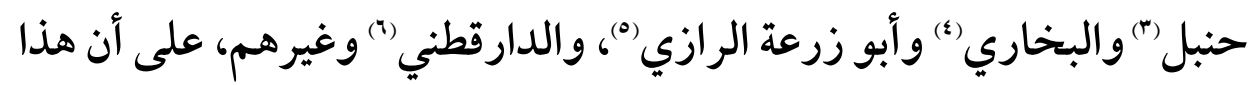

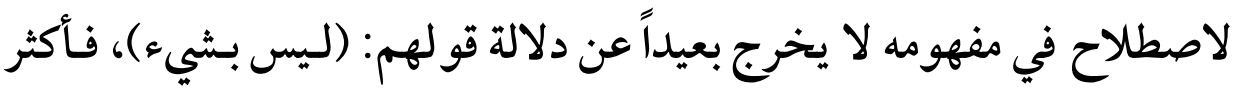

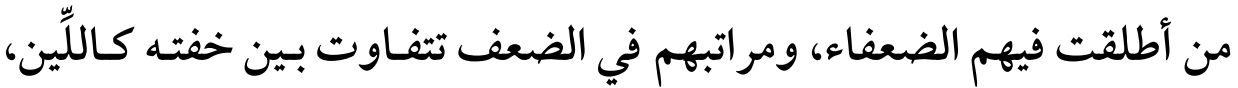
وشدَّته كالتُهمة بالكذب، كما ذكرت عن كثير من أنمة النقد سابقاً.

(1) سؤالات ابن الجنيد (ص: (1) )، فقد سأل ابن الجنيد يحيى بن معين عن قيس بـن

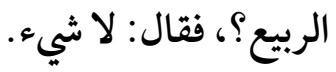

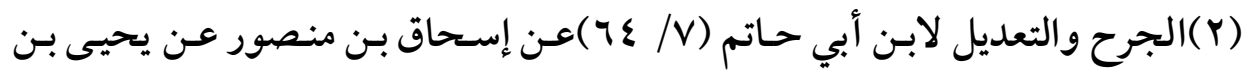

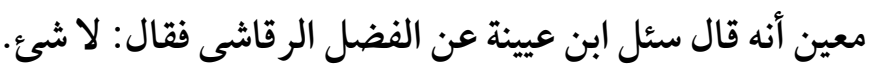

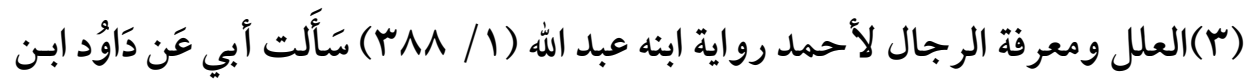

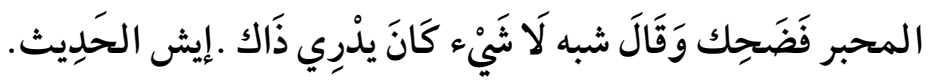

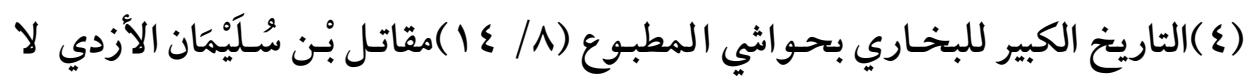
شئ البتة.

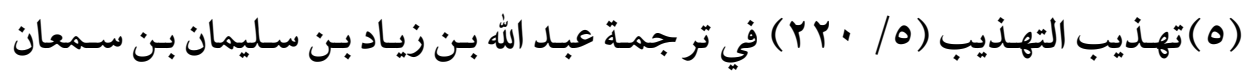

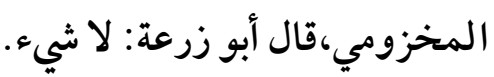

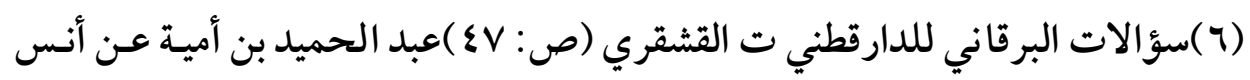




\section{ثانيا: ومن الأمثلة.}

(1) قول ابـ معسين في خالد بـن أيسوب: وفسرها ابـن أبي حساتم الرازي في .

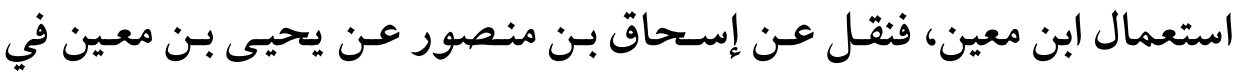

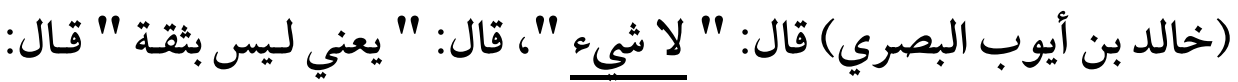
وسمعت أبي يقول: هو مجهول منكر الحديث. (Y) قول البخاري في: يزيد بن عبد الملك بن المغيرة بن نوفل بـن الحـارث

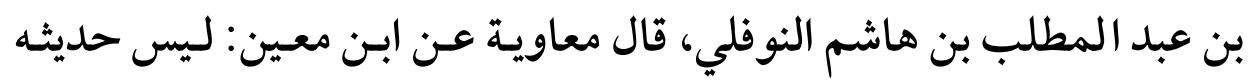

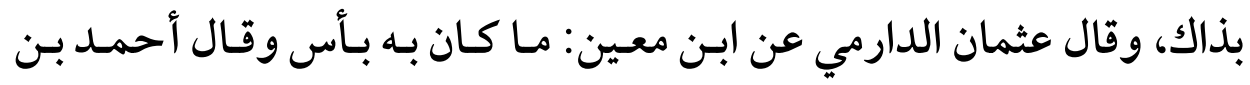
صالح المصري: ليس حديثه بشيء وقال أبو زرعة ضعيف الحديث وقال مرة

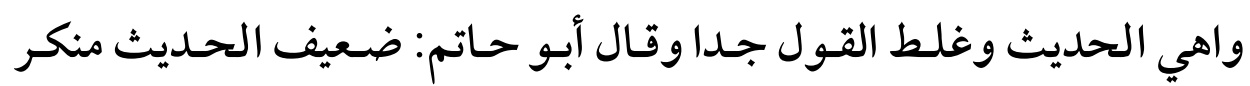
الحديث جدا وقال البخاري: أحاديثه شبة لا شيء وضعفه جدا وقال النسائي: متروك الحديث وقال في موضع آخر : ليس بثقة وقال ابن عدي: ليس حديثه بالكثير وعامة ما يرويه غير محفوظة، وقال ابن سعد كان جلدا صارما ثقة وله

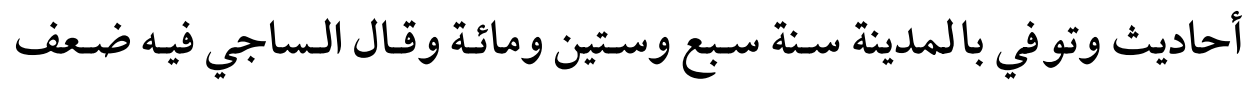
وعنده مناكير وقال ابن حبان لما أخرج له في صحيحه مقرونا بغيره أمـا يزيـد بن عبد الملك فقد تبر أنـا من عهدته في كتاب الضعفاء وقتال الـدارقطني:

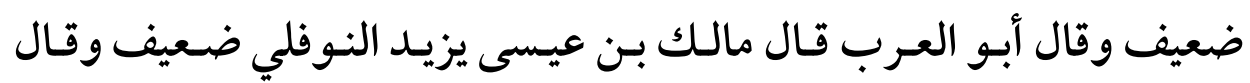

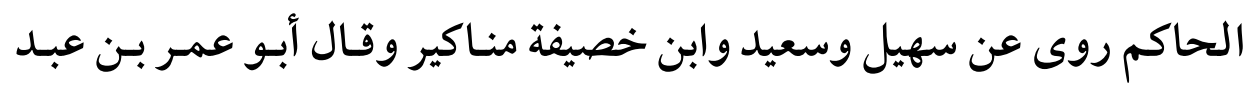

(1) الجرح لجرح والتعديل لابن أبي حاتم (r/ I Ir) . 
(7.)

دلالة المصطلحات الخاصة بين النقاد في تبريح الرواة (دراسة وتحليل)

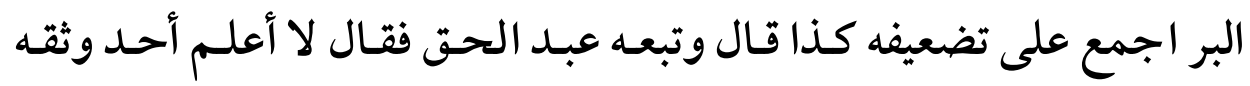

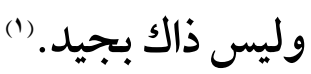

ثاثثاً: الدلالة الخاصة في هذا بـال المصطلح.

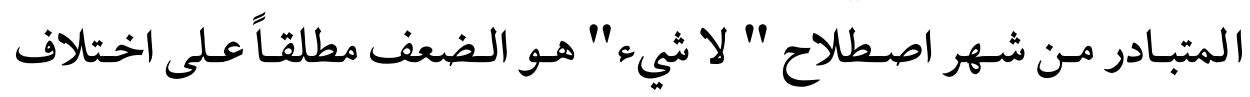
درجاته، وهذا ما تحقق لدينا في المشهور مـن الاصطلاح سـابقاً، غير أنني وجدته قد يطلق على الراوي وير اد به المقل من الرواية الذي لم يتبين حفظه وإتقانه لقلّة حديثه، وليس لضعفه. رابعاً: من الأمثلة.

(1) قول الدارقطني: الهجنع بن قيس الكوفي، قال الـدارقطني : لا شيء، لـه حديثان، وذكره ابن حبان في الثقات وقال: روى عن إبر اهيم النخعي (()، وعنه محمد بن طلحة.

(Y)قول ابن معين: هبيرة بن حدير العـدوى، روى عـن سعد الحـذاء وضرار بن عمرو، روى عنه إسحاق بن سالم الضبى البصري الصائغ، قال ابن أبي حاتم: ذكره أبي عن إسحاق بن منصور عن يحيى بـن معين أنه قال: هبيرة

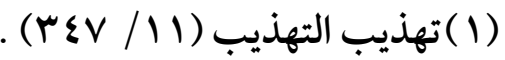

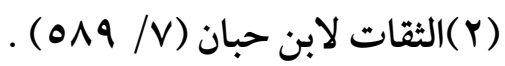

$$
\begin{aligned}
& \text { (r)لسان الميزان (7/ / (191) . }
\end{aligned}
$$


(7I)

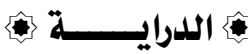

العدوى لا شئ، وقال سـألت أبى عن هبيرة العدوى؟ فقـال: شيخ. (1) وقـال العجلي: كوفى ثقة. (ن) وقال الذهبي: حدث عنه محمد بن موسى الحرشي. (")

$$
\begin{aligned}
& \text { (1) الجرح والتعديل لابن أبي حاتم (9/ (11) . }
\end{aligned}
$$

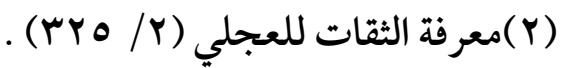

$$
\begin{aligned}
& \text { (r) ميزان الاعتدال (乏 / rه ץ) . }
\end{aligned}
$$


(Tr)

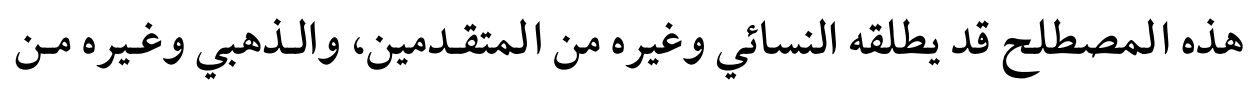

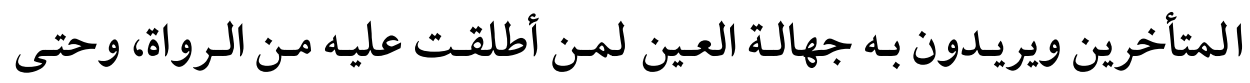

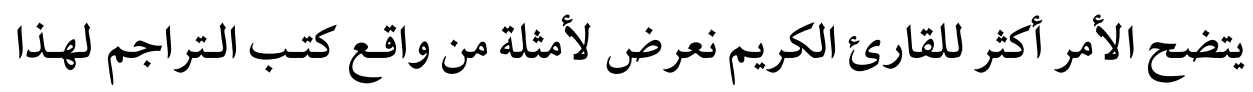
المصطلح. ثانياً: ومن الأمثلة. ومسن الأمثلة الدالة على مسلك الاملك النسائي والذهبي في دلالة مصطلح ليس بالمشهور بمعنى مجهول العين:

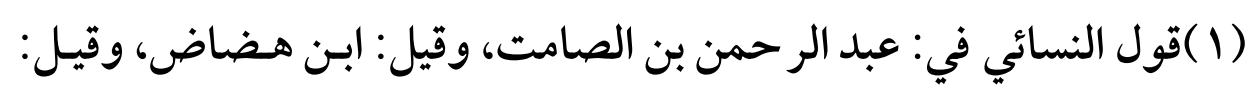

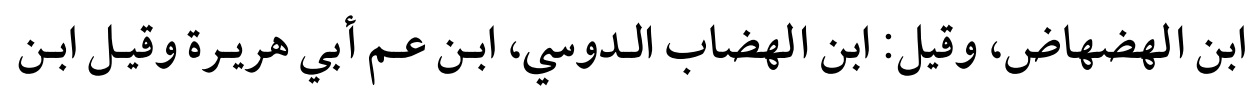

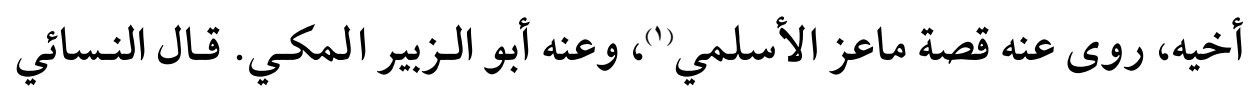
عقب روايته: ليس بالمشهور، وذكره ابن حبان في الثقات، وقال البخاري: لا

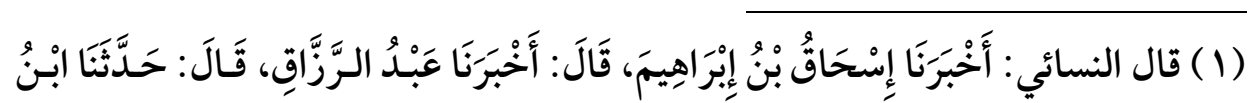

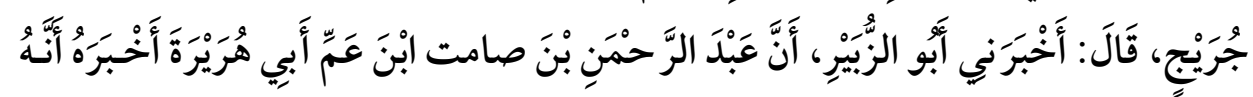

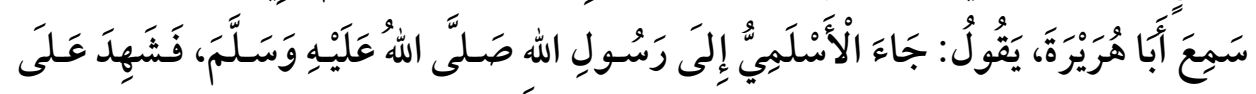

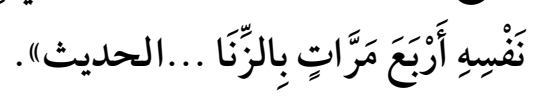

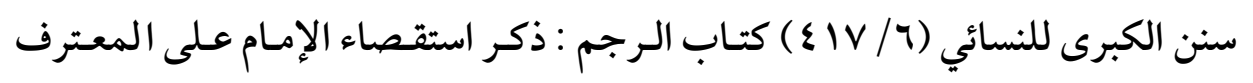

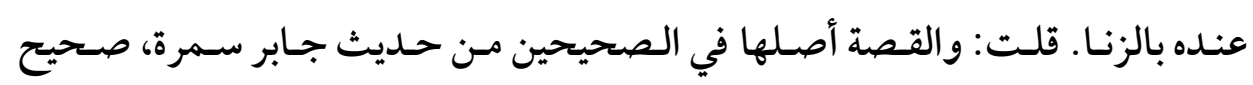

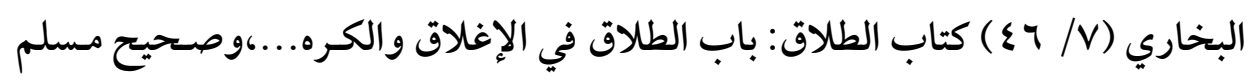

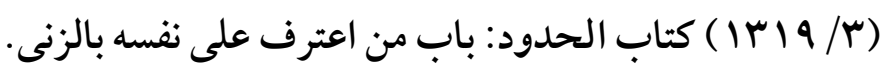


يعـرف إلا بهـذا الحـديث، وقـال البنـاني في ذيـل الكامـل : مـ لا يعـرف إلا بحديث واحد ولم يشهر حاله فهو في عداد المجهولين، قلت وقال البخاري

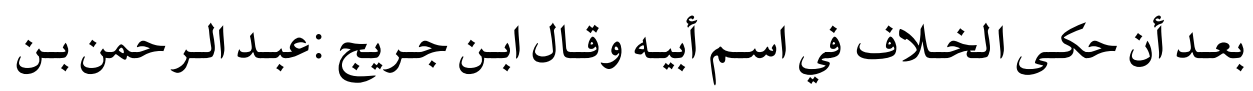

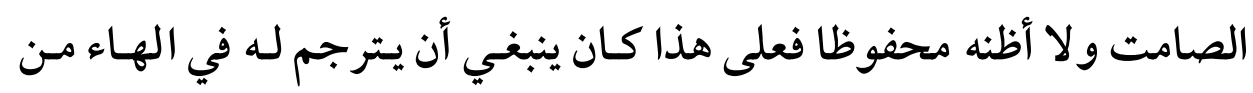
(1). (1) أسماء الآباء نخلص مما سبق أن قول النسائي في هـذا الراوي: ليس بمشهور، مصطلح

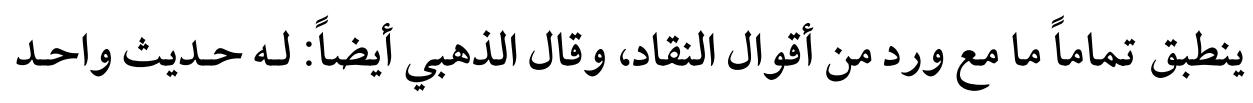

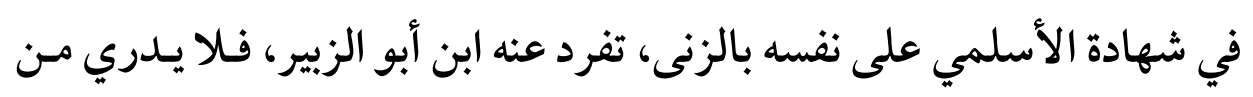

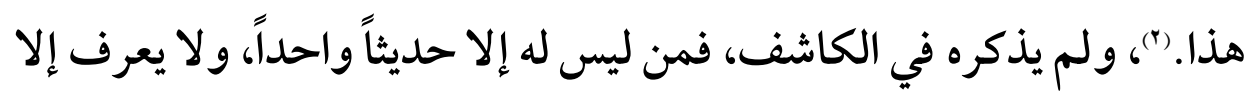

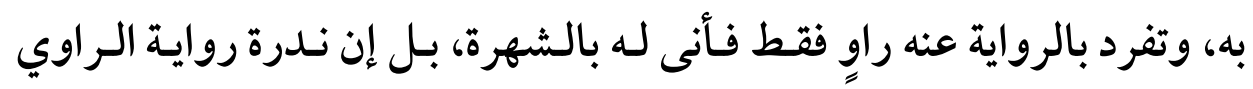

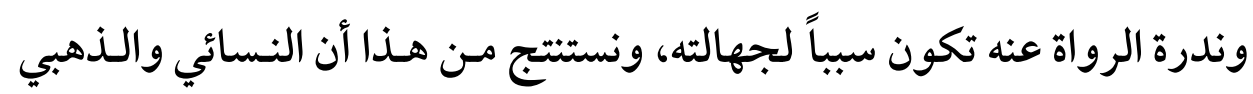

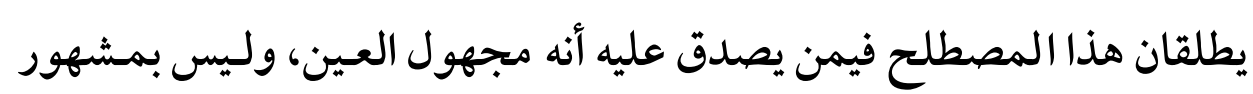

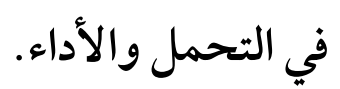

(Y) قول عبد الحق الإشبيلي: أبو هند البجلي شامي، روى عن معاوية، وعنه

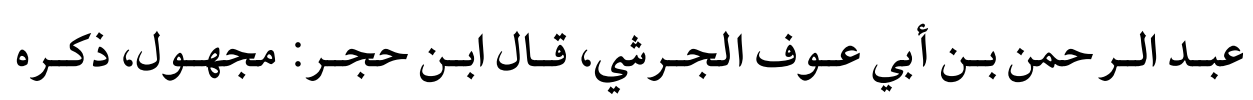

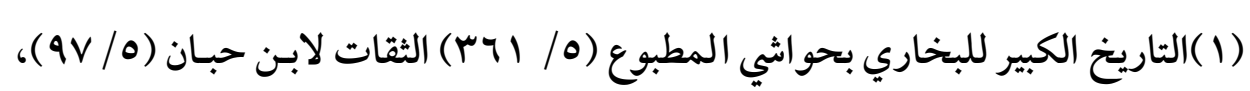

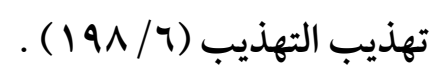

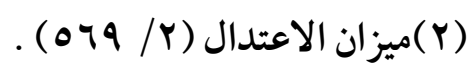


(7६)

العسكري في الصحابة، وقال عبد الحق: ليس بالمشهور، وقال ابـ القطان مجهول، وقال الذهبي :لا يعرف، وقال في الديوان: مجهول. (1)

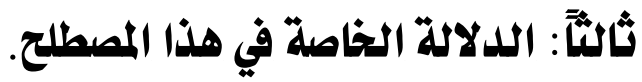

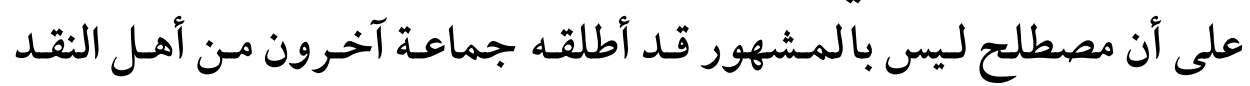
وعنوا بـه دلالة أخـرى عـلى الر اوي، بـأن يكـون ممـن لم يـشتهر بين الرواة

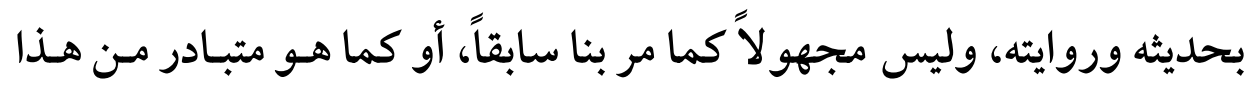
المصطلح، ومن هؤلاء أحمد، وأبو حاتم الرازي، والنسائي أيضاً، وغيرهم. رابعاً: ومن الأمثلة. (1 )قول أحمد أبي حاتم في إبر اهيم بن عبيد بن رفاعة بن رافع بن مالك بـن

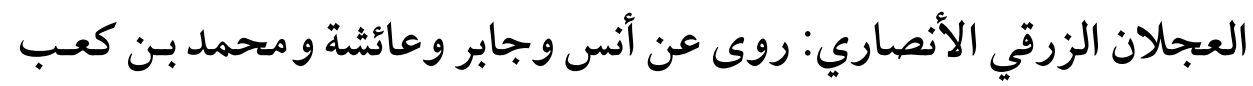
القرظي وغيرهم.

وعنه عيـاض بـن عبد الله الفهري وابـن أبي ذئبـ وابـن جـريج وعـدة. وقـال

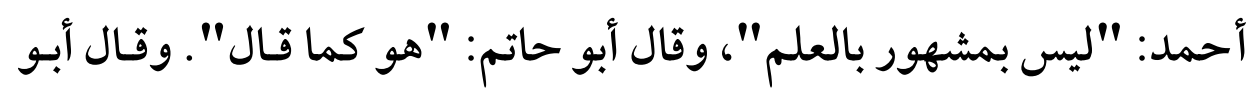
زرعة: "مدني أنصاري ثقة"، وذكره ابن سعد في الطبقة الثالثة مـن المدينة. وذكره ابن حبان في الثقات، وقال ابن حجر :صدوق من الرابعة . (ب)

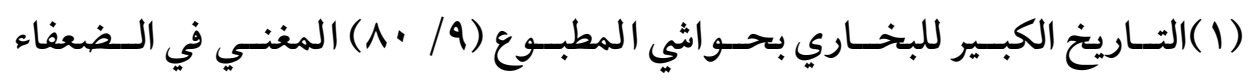

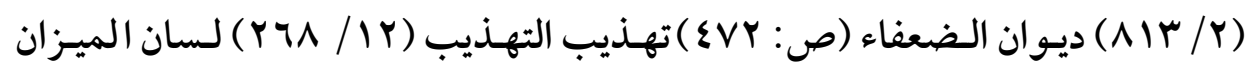
. ( $\varepsilon \wedge \wedge / \vee)$

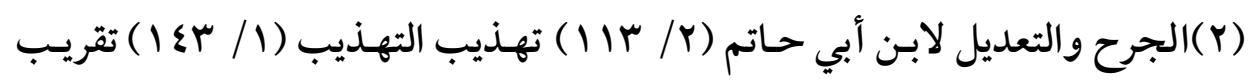
التهذيب (ص: r ) 
(70)

ـ قلت: قول أحمد وأبي حساتم: ليس بالمشهور، لا يعنى أنه مجهول، وإلا

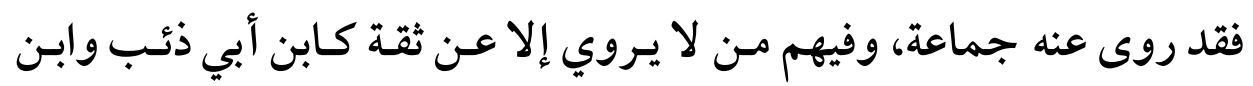
جريج، فضلا عن توثيق من وثقه. إذاً فهو غير مشهور بالرواية عندهما. (Y)قول النسائي في: حسان بن الضمري، وهـو حسان بـن عبد الله الشامي،

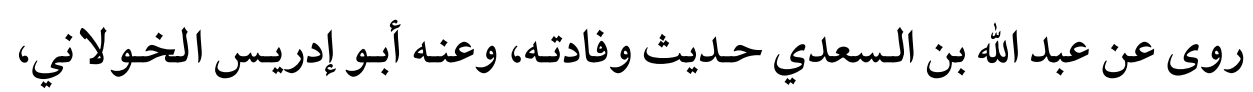

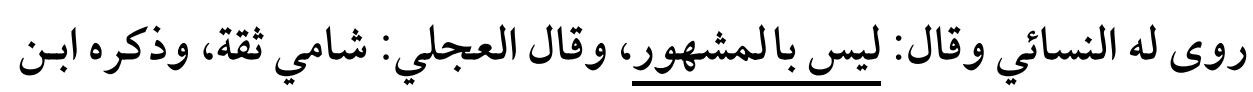

حبان في الثقات، وقال ابن حجر : ثقة مخضرم. (1)

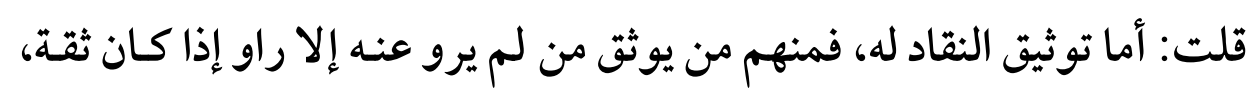

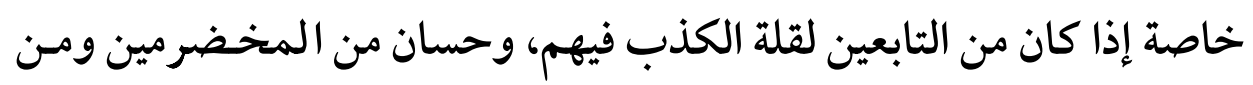
قال: ليس بمشهور يعني لقلة حديثه الذي تسبب في قلة الرواة عنه، وهو مـراد النسائي من قوله فيه ليس بمشهور. 
أحلدهما: الخبر غير المطابق لمخبره، وهو نوعان: كذب عمد، وكذب انب خطأ، فكذب العمـد معـروف، وكـذب الخطأ ككـذب أبي السَّنَابِلِ بْنْ بَعْكَكٍ في

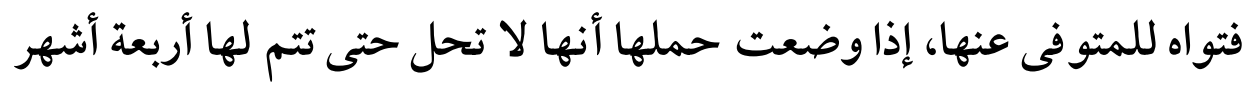

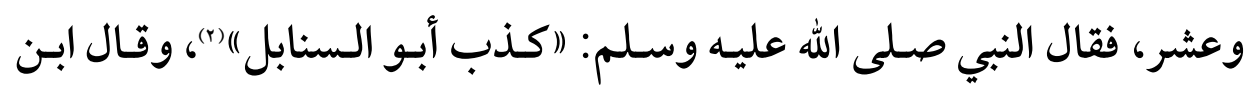
حجر : إن للعالم إذا كان عنده علم بشيء فسمع غيره يذكر فيه شيئا بغير علم

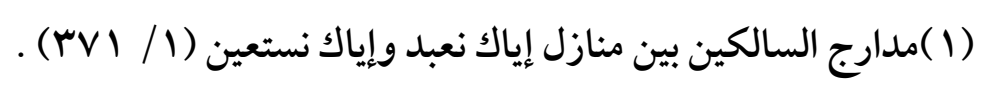

(Y) الحديث بهذا اللفظ أخرجه الشافعي في الرسالة مسند الشافعي (ص: ؟ ؟ ؟ ) )

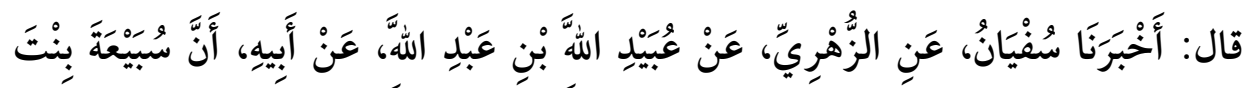

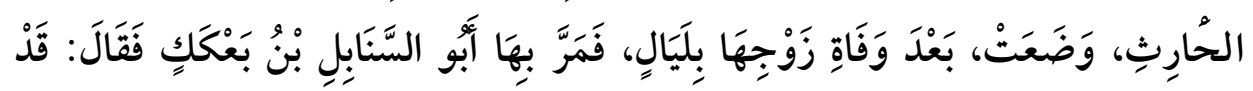

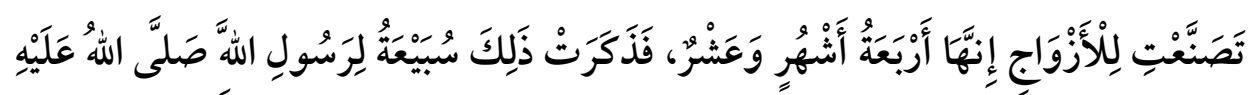

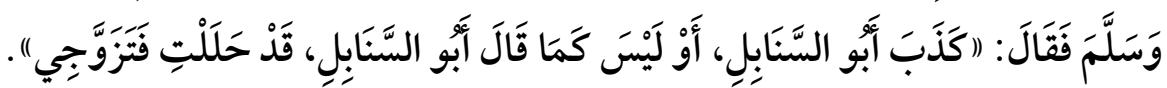

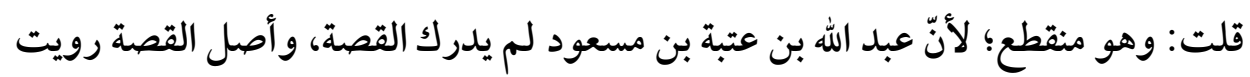

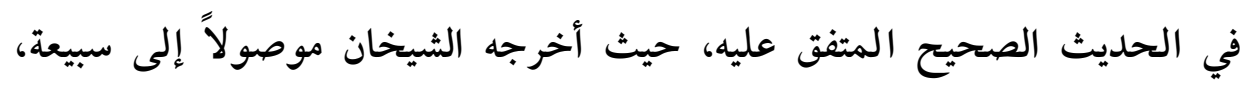

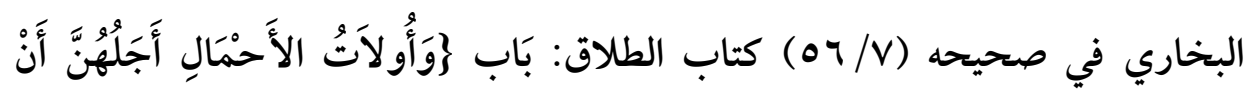

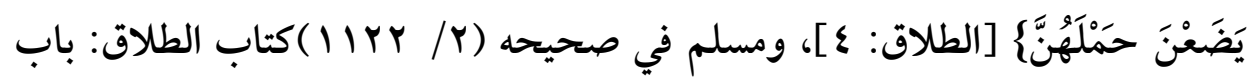
انقضاء عدة المتوفى عنها زوجها، وغيرها بوضع الحمل. 
أن يكذبه، ونظيره قوله صلى الله عليه وسلم: كذب أبو السنابل، أي أخبر بـما هو باطل في نفس الأمر. (1) وقيل : كذب هنا يعني: أخطأ؛ لأن الكذب - في لغة الحجازيين - يطلق على لى

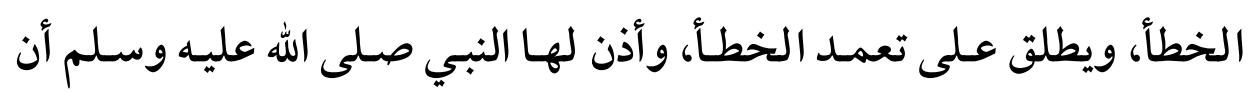
تتزوج، يقول: "فنكحت قبل أن يمضي عليها أربعة أشهر وعشر".

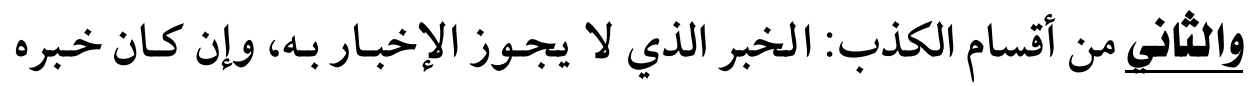

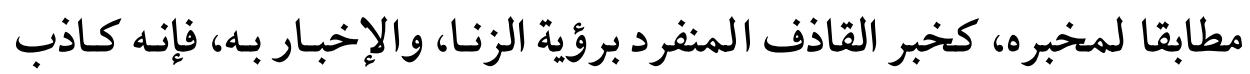
في حكم الله، وإن كان خبره مطابقا لمخبره، و لهذا قال تعالى \}فيإذ لم يأتوا بالشهداء فأولئك عند الله هم الكاذبون) (() فحكم الله في مثل هـذا أن يعاقب عقوبة المفتري الكاذب، وإن كان خبره مطابقا. ـ قلت: أطلق النقاد مصطلح " كذاب" على بعض الرواة وعنوا به ما كان من

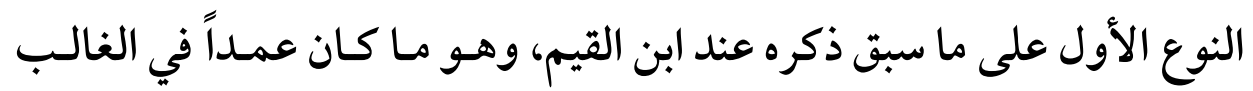
المشهور . ومراتب ألفاظ التجريح على خمس مراتب وجعلها ابن أبي حاتم وتبعه ابن الصلاح أربع مراتب، المرتبة الأولى وهي أسوؤها أن يقال: فـلان أنسان

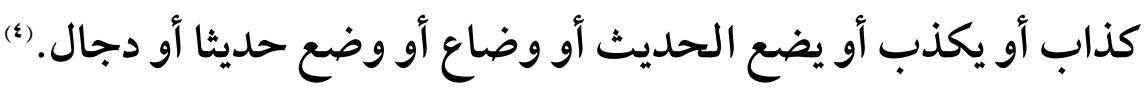

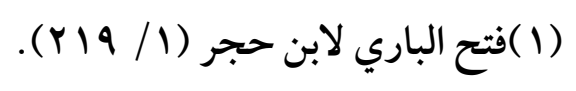

(Y) فتح ذي الجلال والإكرام بشرح بلوغ المرام ط المكتبة الإسلامية (0/ V • (1) ) (r) [النور: rاب]

$$
\text { ( ) (الرفع والتكميل (ص: (101) ) . (1) ). }
$$


(T^)

(1)من النقاد من أفرد مصطلح الكذب في الراوي، مثل:

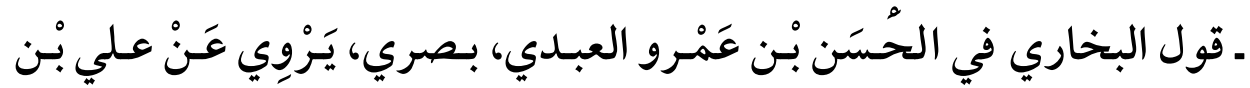

سويد وأَبي نعامة، كذاب.

ــوقول عبـد الله بـن أحمـد: سـمعت أبي يقـول: المعلى بـن هـلابل الطحسان

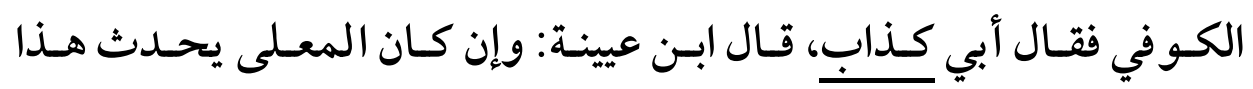

الحديث عن ابن أبي نجيح الذي رأيناه ما أحوجه أن تضرب عني عنه.

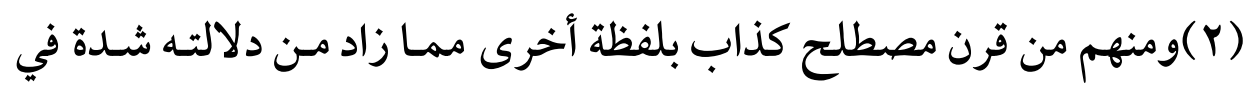
التجريح، كما في ترجمة: ـ إسحاق بن نجيح الملطي الأزدي أبو صـالح ويقـال أبـو يزيـد سكن بغــاد،

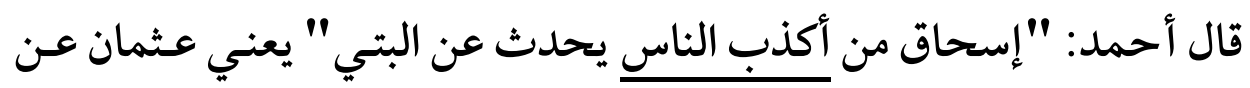

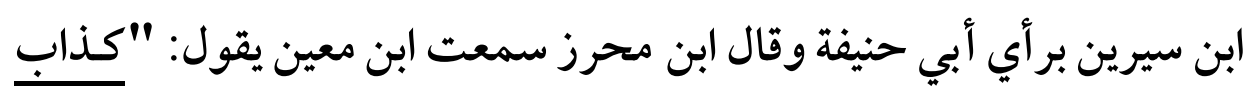

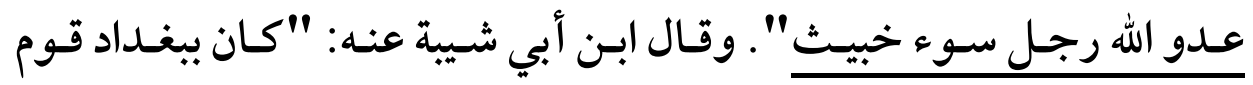
يضعون الحديث منهم إسحاق بن نجيح الملطي" وقال ابـن أبي مريمعنه:

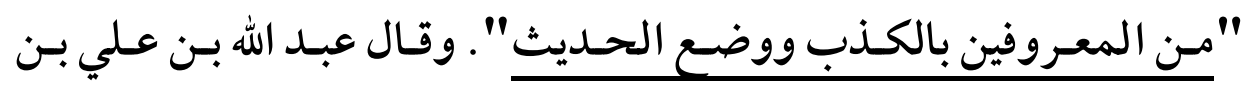

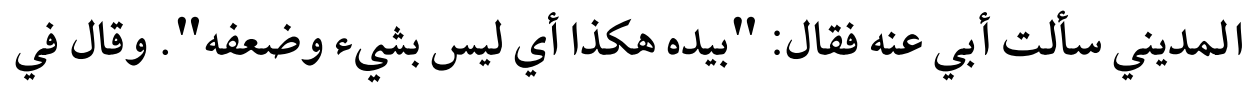
موضع آخر : "روى عجائب". وقال عمرو بـن علي: "كـذاب كان يضع

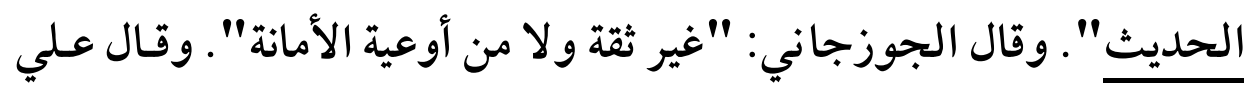

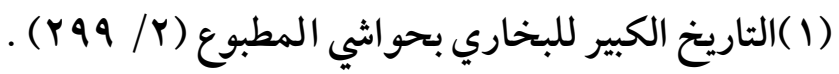

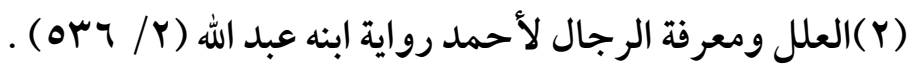


(79)

بن نصر الجهضمي: والبخاري: "منكر الحديث" وقـال النسائي: "مـتروك الحـديث" وقـال يعقـوب الفسوي: "لا يكتـب حديثـه" وقـال صـالح بـن

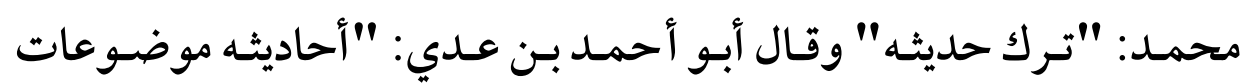

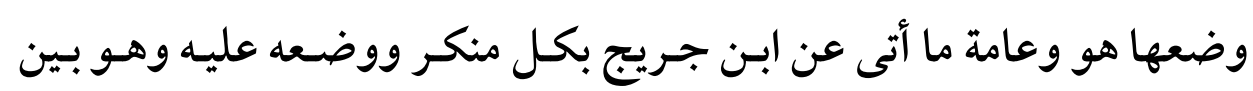

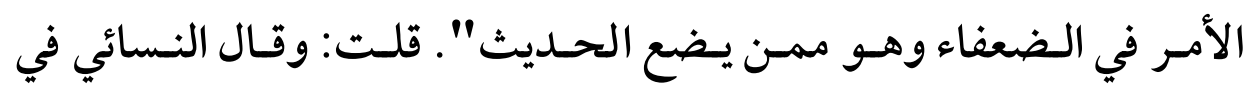

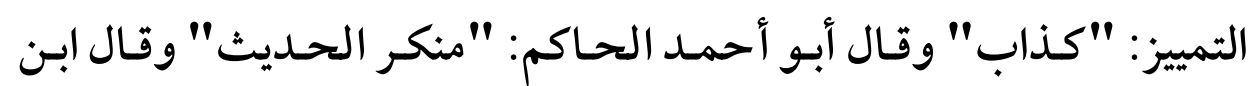
حبان: "دجال من الدجاجلة يضع الحديث صراحا" وقال البرقي: "نسب

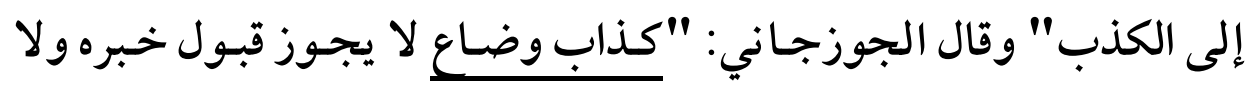

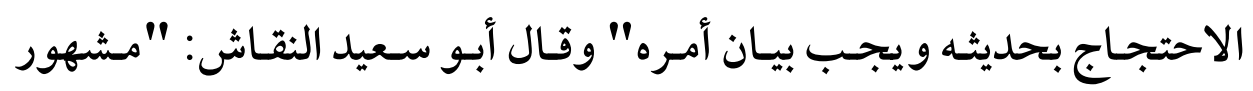

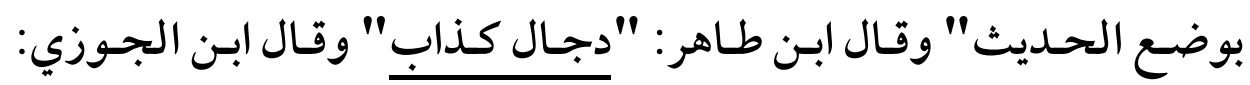
"أجمعوا على أنه كان يضع الحديث" وذكره الدولابي والساجي والعقيلي وغيرهم في الضعفاء. (1) ثالثًا: الدلالة الخاصة في هذا الضعفاء المصطلح.

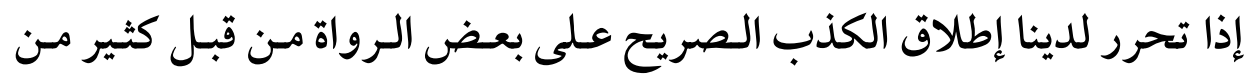

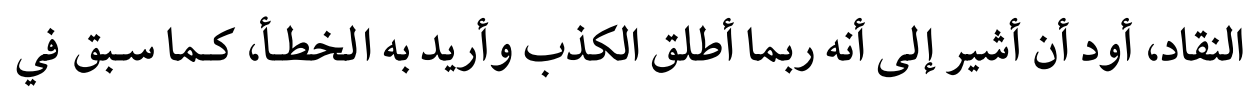
نص ابن القيم، ومثل له بعد أمثلة، هذا من جانب.

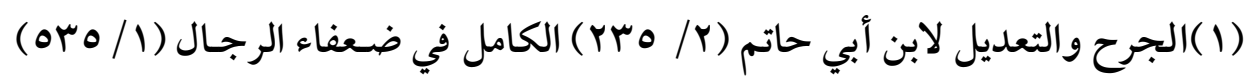

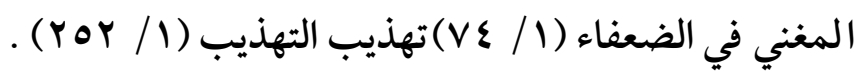




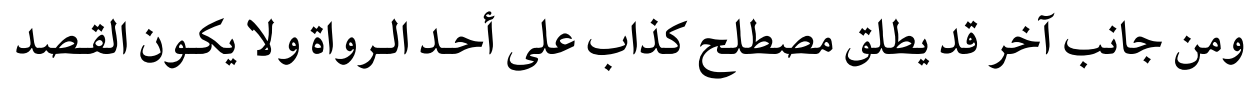

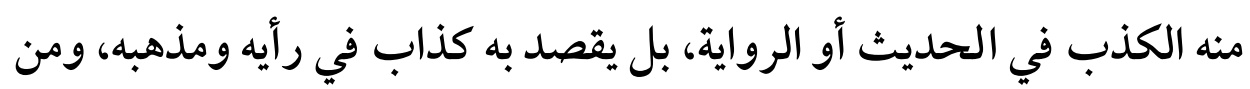

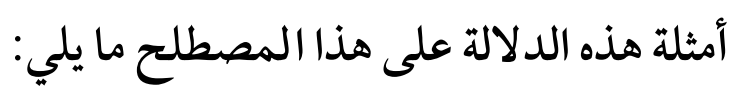
رابعاً: ومن الأمثلة. (1 ) دلالة الكذب على ما كان خطأ مثل:

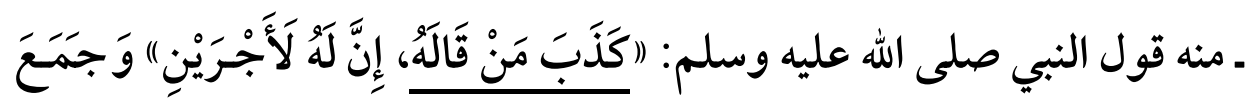

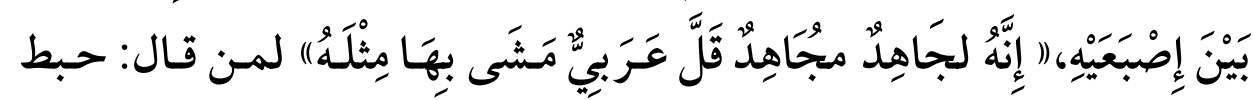

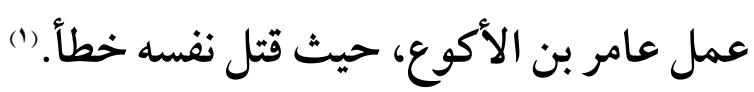

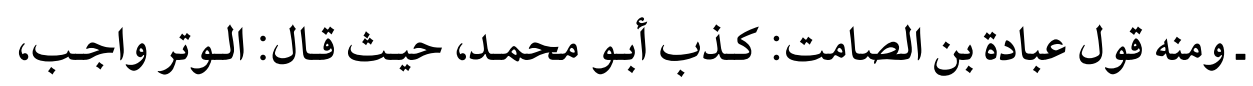

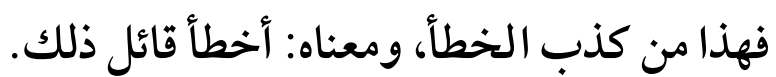

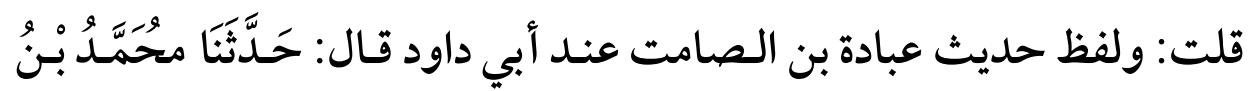

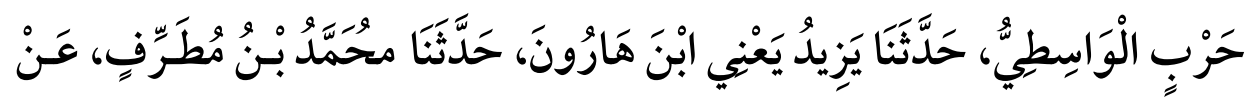

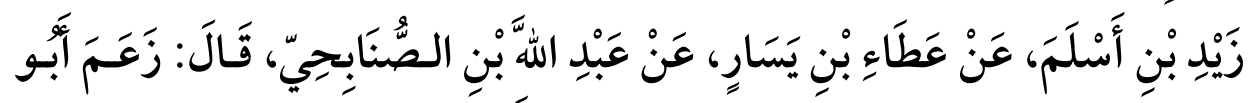

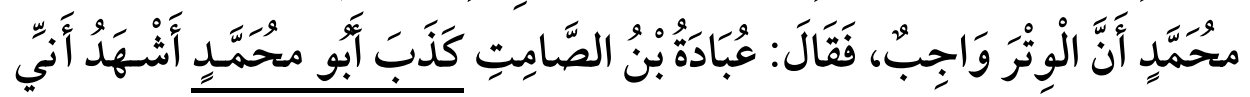

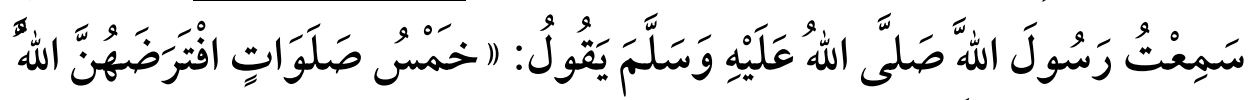

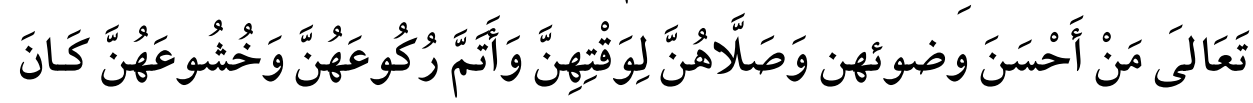

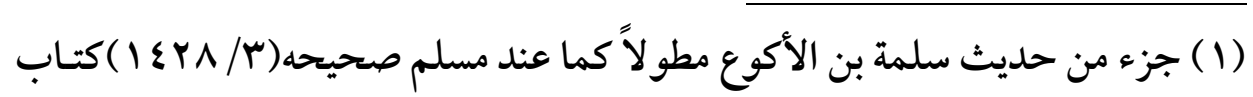
الجهاد والسير : باب غزوة خيبر. 
(VI)

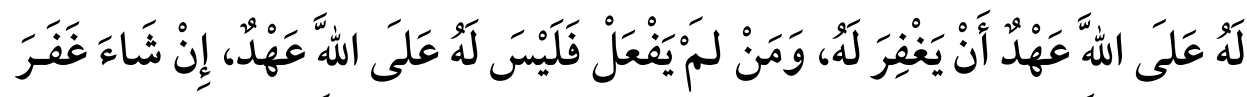

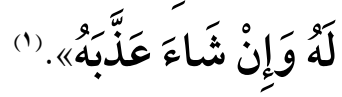
(Y) دلالة الكذب على ما كان في رأي الراوي ومذهبه، مثل قول أحمد وابن

$$
\text { معين والساجي في ترجمة : }
$$

ـ تليد ـ بفتح ثم كسر ثم تحتانية ساكنة ـ بن سليمان المحـاربي أبـو سـليمان، ويقال أبو إدريس الأعرج الكوفي. قـال المروزي عـن أحمـد: "كـان مذهبه التشيع ولم نـر بـه بأسـا" وقـال أيـضا: "كتبـت عنـه حـــيثا كثير اعـن أبي الجحـاف" وقال الجوزجـاني سمعت أحمـد بـن حنبـل يقـول ثنـا تليـد بـن سليمان "هو عندي كان يكذب" وقال ابن معين: "كان بيغداد وقـد سمعت منه وليس بشيء" وقال في موضع آخر : "كذاب كان يشتم عثمان" وكل من شتم عثمان أو طلحة أو واحـدا من أصسحاب رسول الله صلى الله عليه وآلـه وسلم دجال لا يكتب عنه وعليه لعنة الله والملائكة والنـاس أجمعين، وقال أيضا: قعد فوق سطح مع مولى لعـثمان فتنـاول عـثمان فأخـذه مـولى عثمان فرمى به من فوق السطح فكسر رجليه فقام يمشي على عصا. وقـال البخـاري

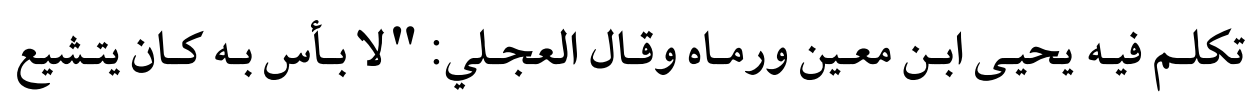

(1) سنن أبي داود ( / / 1 1) كتاب الصلاة: باب في المحافظة على وقت الصلوات،

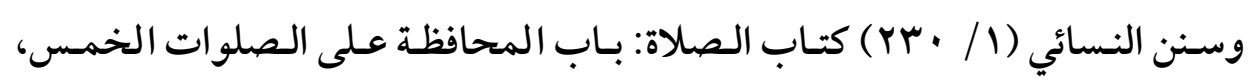
وصححه الألباني: ينظر : صحيح وضعيف سنن أبي داود ( / / Y ع ) . 
ويدلس" وقال ابن عـمار "زعمـوا أنـه لا بأس بـه" وقـال أبـو داود "رافضي لهي خبيث رجـل سـوء يشتم أبـا بكر وعمر "وقـال النسائي: "ضعيف" وقـال يعقوب بن سفيان: "رافضي خبيـث سـمعت عبيد الله بـ موسى يقـول لابنه محمد: أليس قد قلت لك لا تكتب حديث تليد هذا" وقال صالح بن محمد كـان أهـل الحـديث يـسمونه: "بليـدا" يعنـي بالبـاء الموحـدة "وكـان سيء الخلق لا يحتج بحديثه وليس عنده كثير شيء" وقال ابن عدي: "يتبين على رواياته أنه ضعيف" روى له الترمذي حديثا واحدا في المناقب. قلت: وقال الساجي: "كذاب"، وقـال الحـاكم وأبـو سعيد النقـاش: "رديء المـذهب منكـــ الحـديث روى عـن أبي الجحــاف أحاديـث موضـوعة" زاد الحـاكم "كذبـهـ جماعـة مـن العــماء" وقــال أبـو أحمــد الحـاكم: "لـيس بـالقوي عندهم" وقال ابن حبان: "كان رافضا يشتم الصحابة" وروى في فضائل أهل البيت عجائب وقال الدارقطني: "ضعيف" وقال ابن حجر : ضعيف من (1). الثامنة

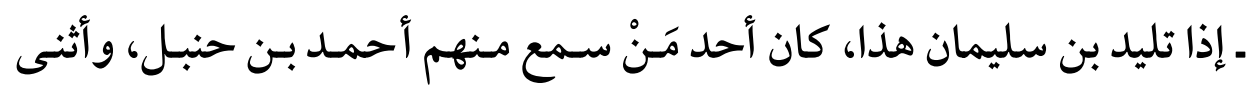
عليه في قول، لكنهم نقموا عليه مذهبه في التشيع، وغَلَّظّ يحيى بن معين فيه

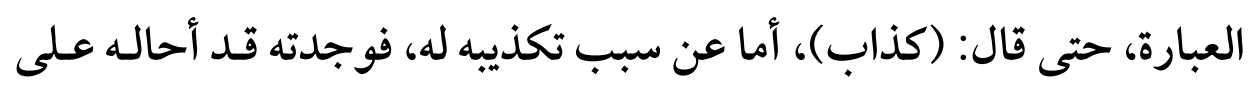
مذهبه لا على حديثه، إذ نَصُّ مقالة يحيى بـن معين كما رواهـا عنه عبـاس

$$
\text { (1) تهذيب التهذيب (1/ / 0.9 ) تقريب التهذيب (ص: • rا ). }
$$


الدوري: " تليد كذاب، كان يشتم عثمان، وكل مَنْ يشتم عثمان أو طلحة أو أحداً من أصحاب البي صلى الله عليه وسلم دجال، لايُكتب عنه، وعليه لعنة الله وا لملائكة والناس أجمعين". فتأثرت طائفة جاءوا من بعدُ بعبـارة يحيى

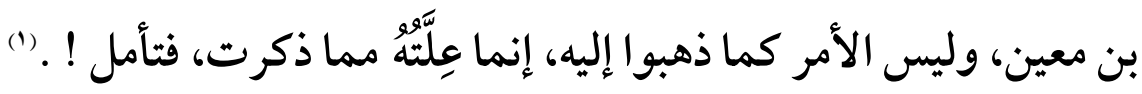




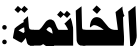

الحمد لله رب العالمين، وأشهد أن لا إله إلا الله وحده لاشريك لـه، و أشـهد

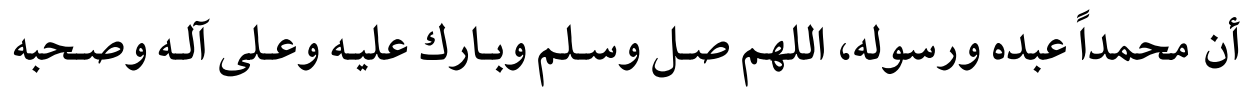

$$
\text { ومن تبعه إلى يوم الدين. وبعد: }
$$

من خلال هذه الدراسة، فقد طوفت بالعديد من مصادر السنة النبوية، وغيرهـا

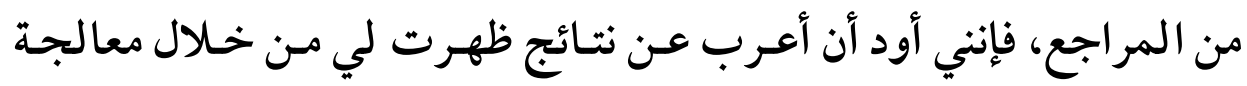
فكرة هذا البحث المتو اضع، وذلك في النقاط التالية:

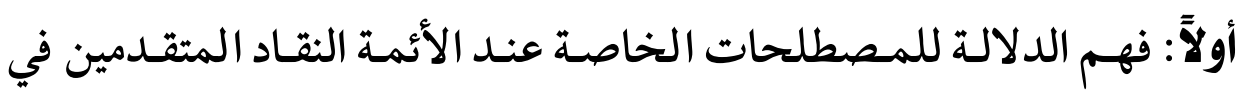
جرح الرواة حسب استعمالهم لها، عَن طريق الجمـع والاستقر اء والدراسة

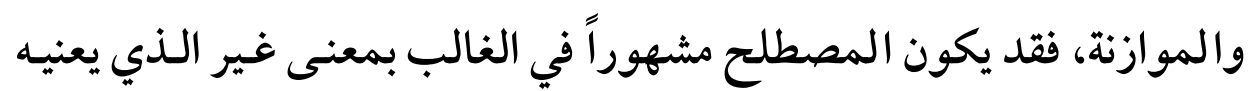
أحد النقاد في إطلاقه على أحد الرواة.

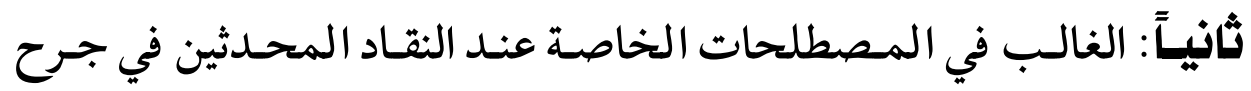
الرواة أن تكون مشهورة في دلالتها بينهم، إلا إذا ورد صارف لهاعن المعنى

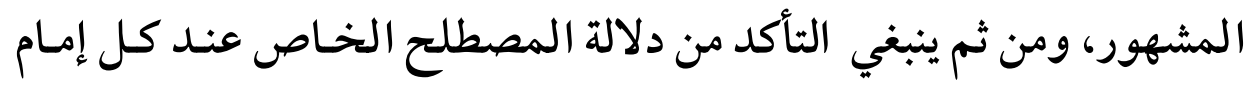
قبل إصدار الحكم على الراوي؛ كي تأتي النتيجة منضبطة وصحيحة.

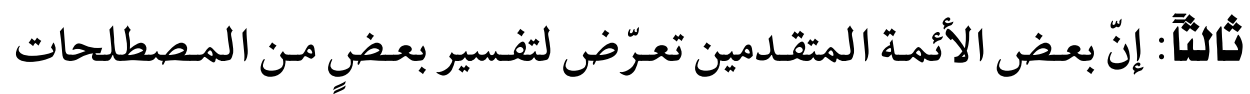

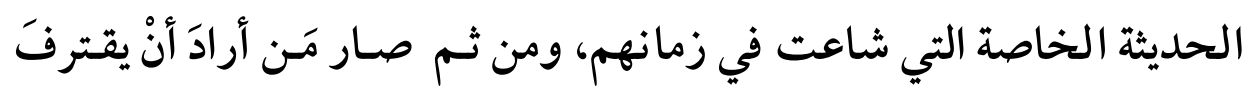

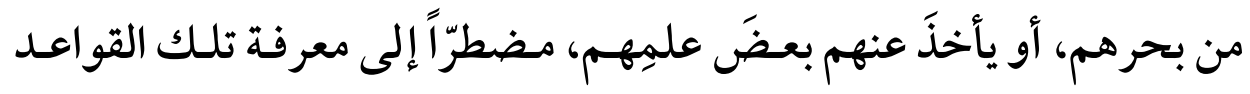

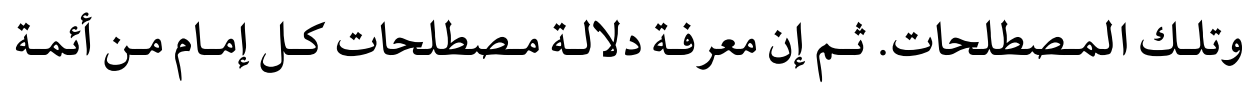
الحديث على سبيل التحقيق والتفصيل، أمر فيه مـن الصعوبة والغمـوض مـا 
(vo)

يعجز - بسببه - بعض الباحثين، فلا بد من أن يشارك كثير مـنهم في دراسة مسائل هذا الباب. رابعاً: دراسة الدلالة للمصطلحات هداب الخاصة في جرح الرواة في بـاب واحـد

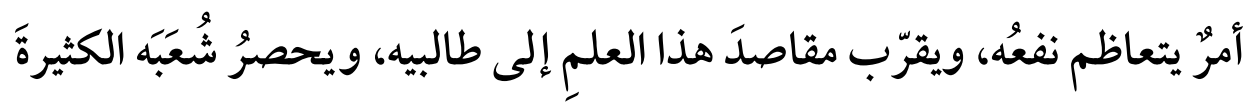

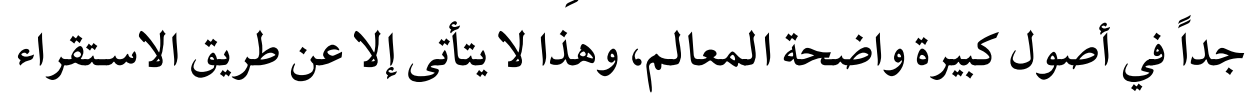

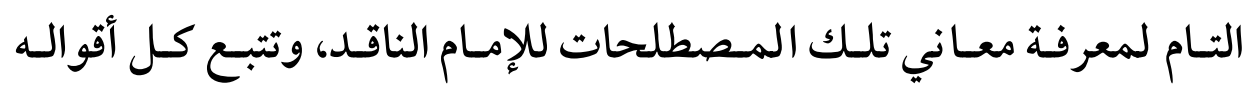
ودراستها، ودراسة كل ما يتعلق بها، ممـا لـه شـأن بتعيين معانيها، وموازنة

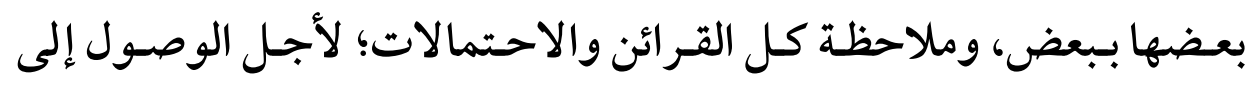
المقصود، وهو الوقوف على دلالة تلك المصطلحات. 


\section{( فهرس المصادر والمراجع)}

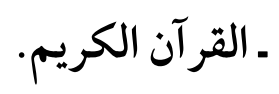

ـ الموقظة في علمم مصطلح الحـديث، المؤلف: شـمس الدين أبـو عبد الله

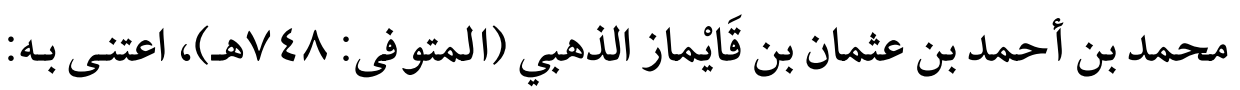

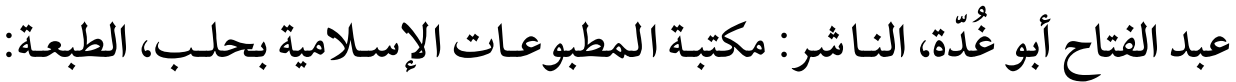

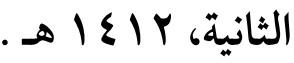

ـــسان المحـدثين،(مُعجــم يُعنى بـشرح مـصطلحات المحـدثين القديمـة والحديثة ورموزهم وإثاراتهم وشرح جملة مـن مشكل عبـار اتهم وغريـب

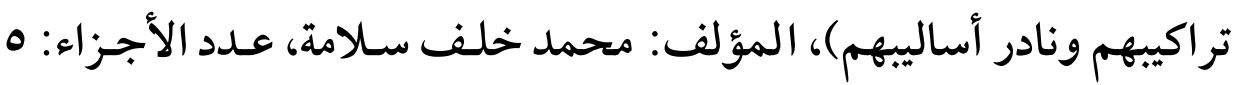
أجزاء، مصدر الكتاب: ملفات ورد نشرها المؤلف في ملتقى أهل الحديث.

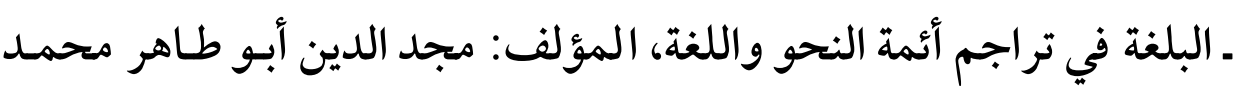
بن يعقوب الفيروزآبادى (المتوفى: N IVهـ)، الناشر : دار سعد الدين للطباعة

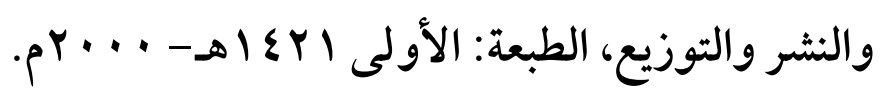

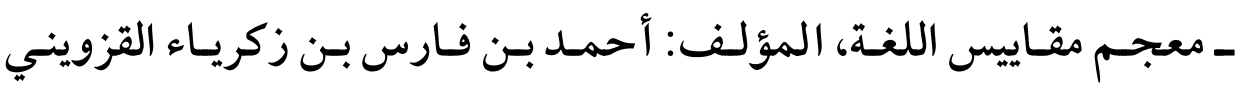

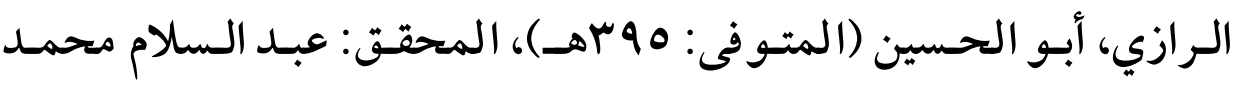

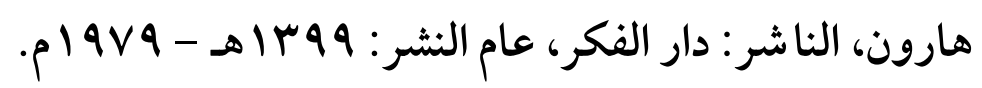
ـ المسند الصحيح المختصر بنقل العدل عن العـل إلى رسول الله صلى الله عليه وسلم، المؤلف: مسلم بن الحجـاج أبـو الحسن القشيري النيسابوري

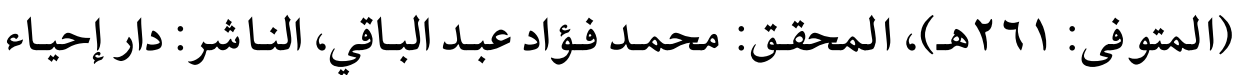

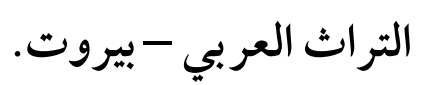




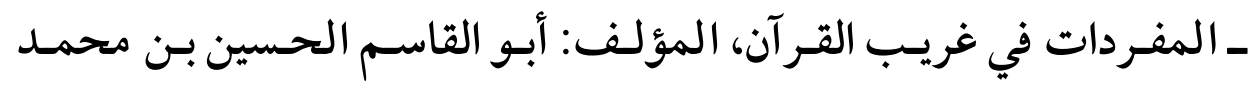
المعروف بالر اغب الأصفهانى (المتوفى: Y •0هـ)، المحقق: صفوان عدنان الداودي، الناشر : دار القلم، الدار الشامية - دمشق بيروت، الطبعة: الأولى .

ـ التعريفات، المؤلف : علي بن محمد بن علي الجرجاني، تحقيق : إبراهيم

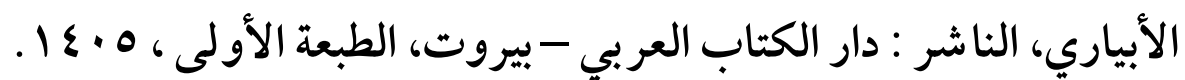
ـ إحكام الإحكام شرح عمـدة الأحكام، المؤلف: ابـن دقيـق العيـد، النـاشر: مطبعة السنة المحمدية، الطبعة: بدون طبعة وبدون تاريخ.

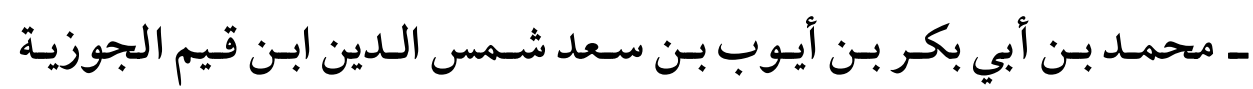

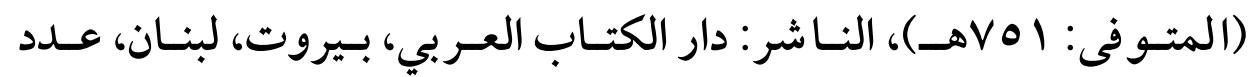

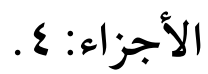

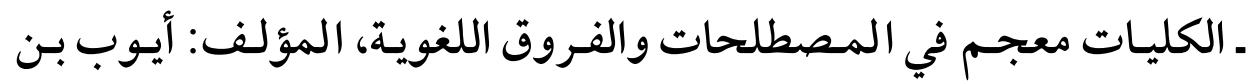
موسى الحسيني القريمي الكفوي، أبو البقاء الحنفي (المتوفى: ؟9 ـ اهـ)،

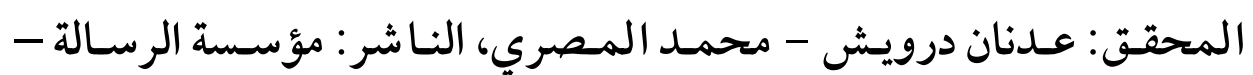
بيروت.

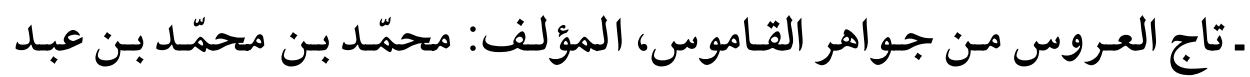

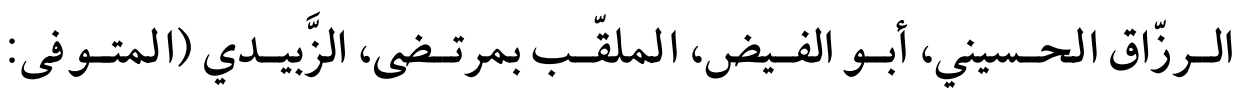
0 · I اهـ)، المحقق: مجموعة من المحققين، الناشر: دار الهداية. 


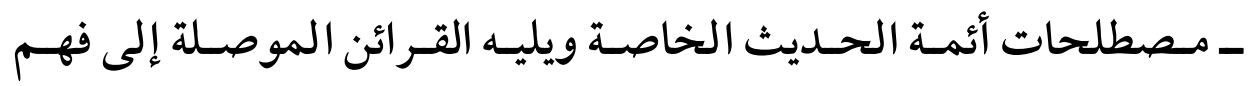

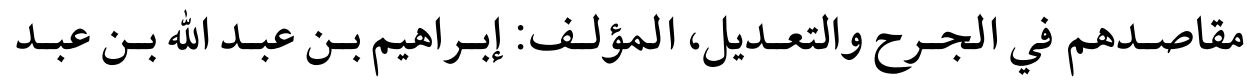

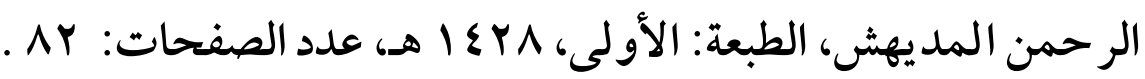
ـ قاعـدة في الجـرح والتعـديل (مطبـوع مـع كتـاب "أربـع رسـائل في علـوم

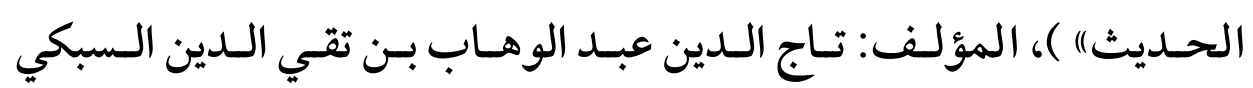
(المتوفى: لحVIهـ)، المحققق: عبد الفتـاح أبـو غـدة، الناشر : دار البشائر -

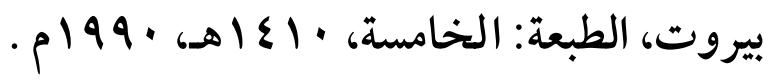
ـ إعلام الموقعين عن رب العالمين، المؤلف: محمد بـن أبي بكر بـن أيوب المبا.

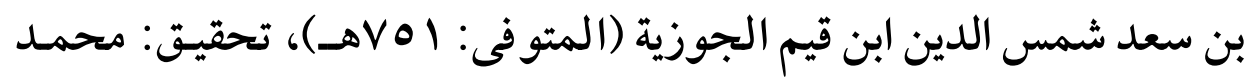

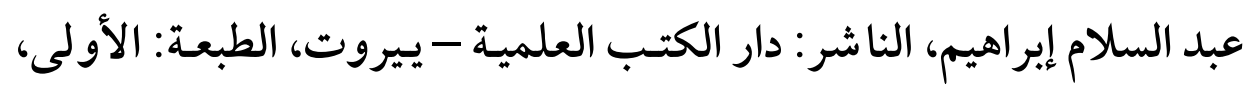

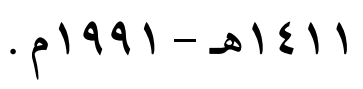
ـ المختصر في علـم الأثر (مطبوع ضـمن كتـاب: رسـالتان في المصطلح،

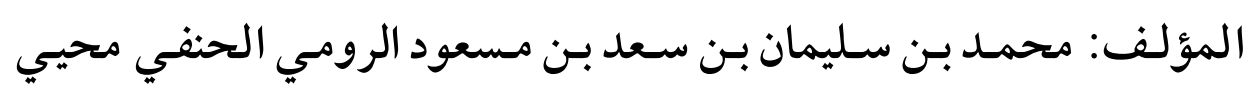

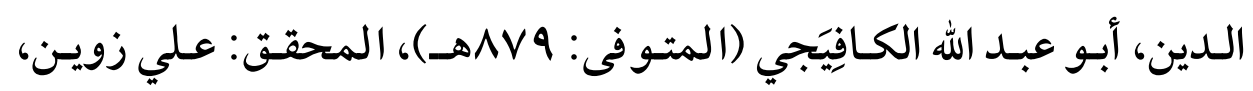

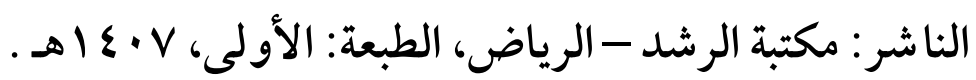

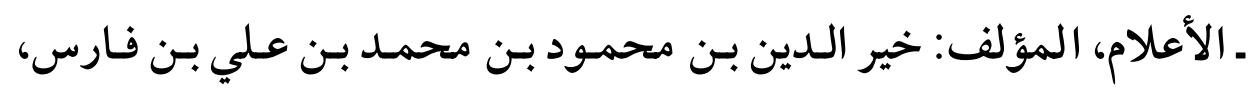

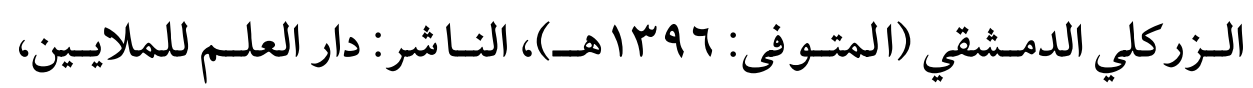

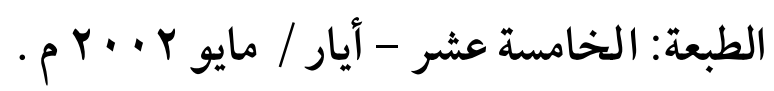

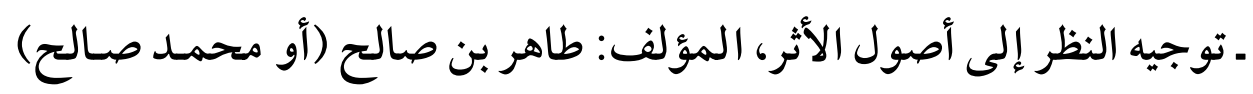

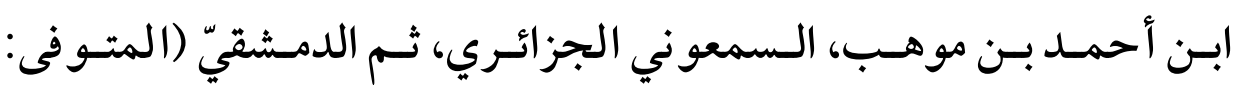




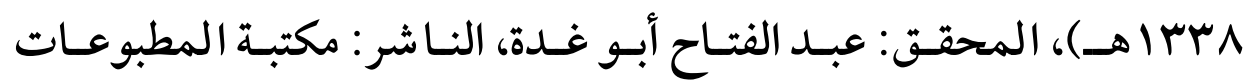

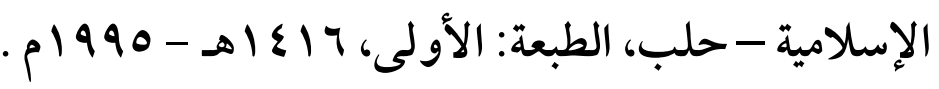
ـ التعديل والتجريح ، لمن خرج له البخاري في الجامع الصحيح، المؤلف:

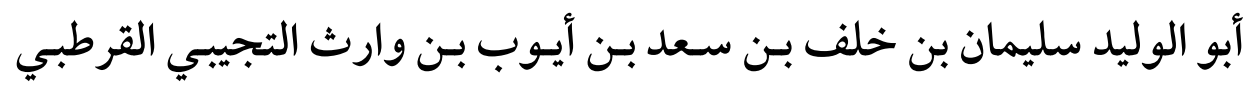

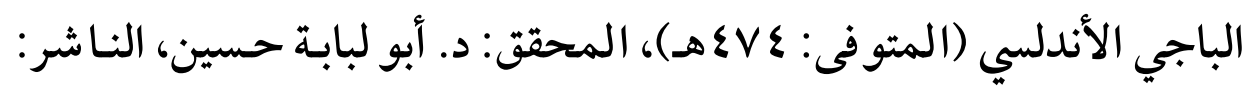

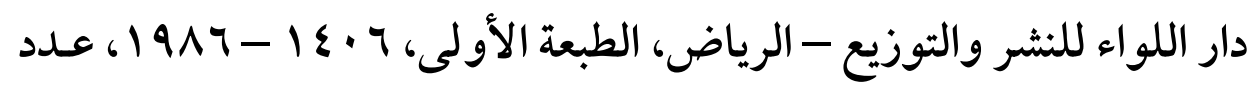

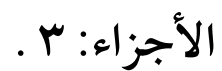
ـ سير أعلام النبلاء، المؤلف : شمس الدين أبو عبد الله محمد بـن أحمـد بـن

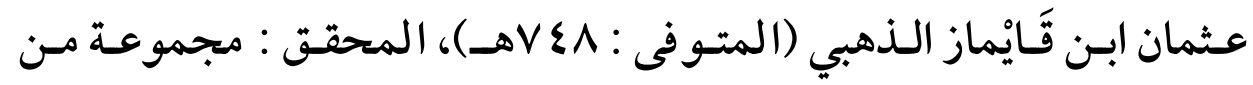
المحققـين بـإشر اف الشيخ شـعيب الأرنـاؤوط، النـاشر : مؤسسة الرسـالة، الطبعة: الثالثة، 0 · ع (1هـ 1910 م م . ـ ميزان الاعتدال في نقد الرجال، المؤلف: شمس الـدين أبـو عبـد الله محمـد

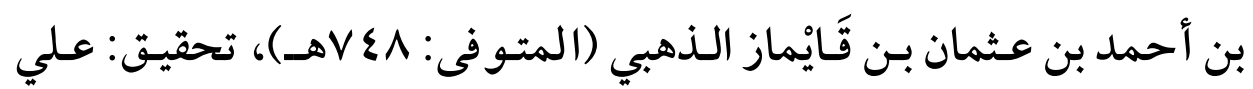

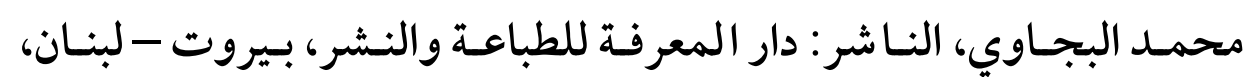

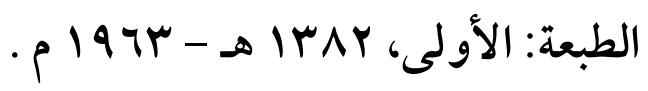

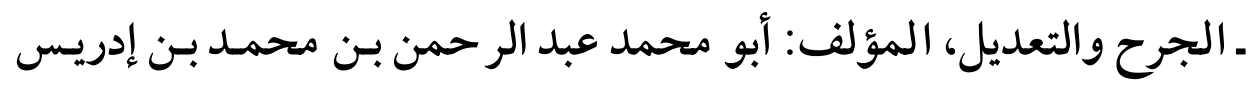

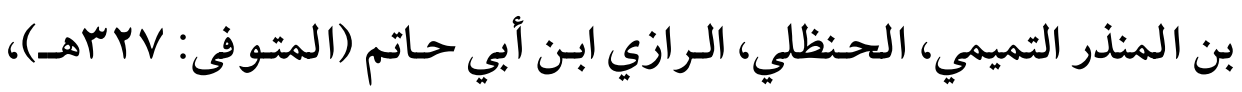

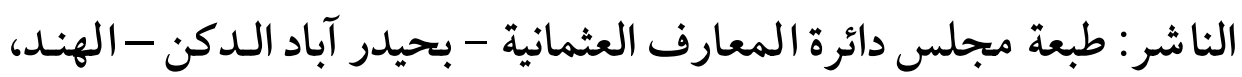

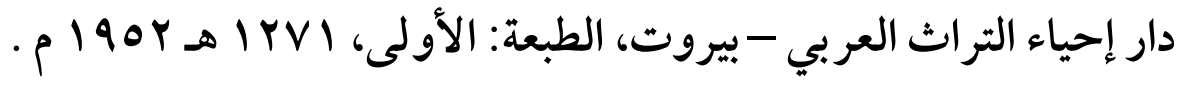




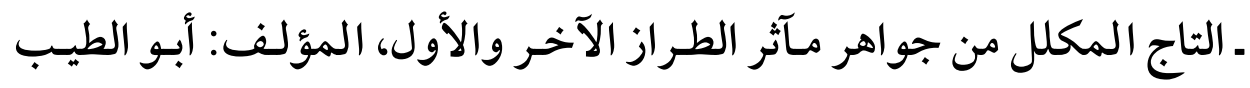

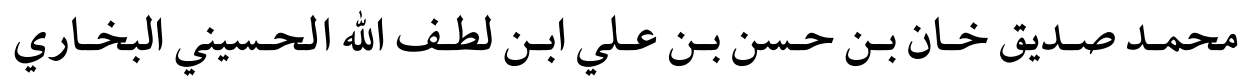

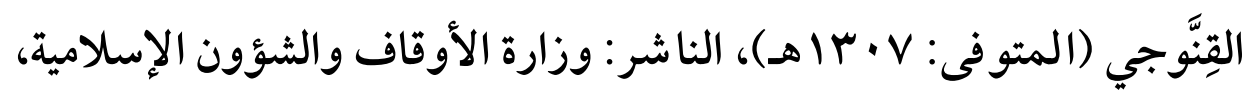

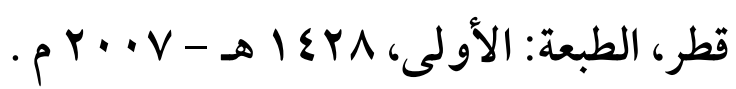
ـ تقريب التهذيب، المؤلف: أبو الفضل أحمد بن علي بـن محمـد بـن أحمـد

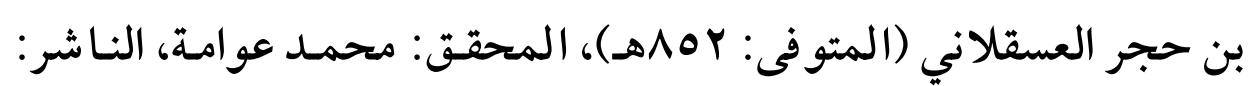

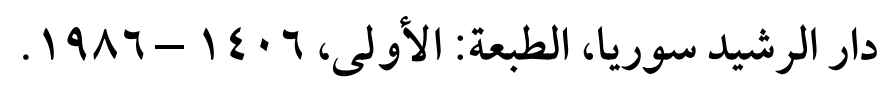

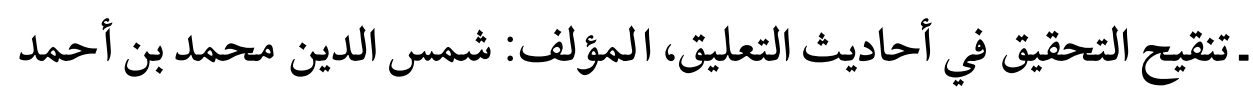

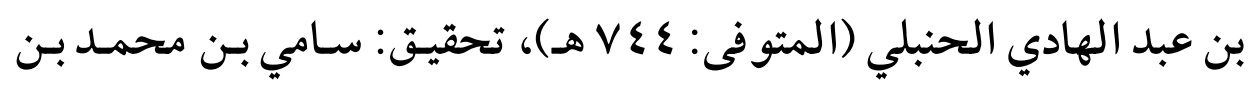

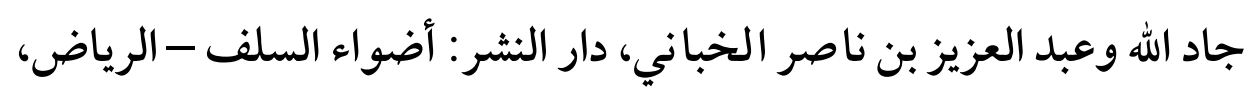

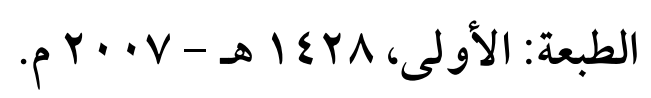

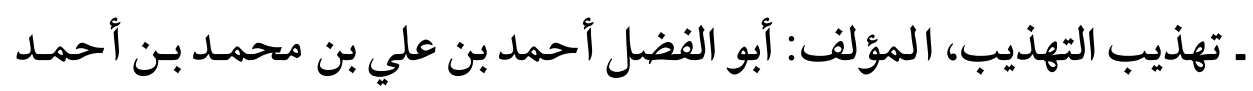

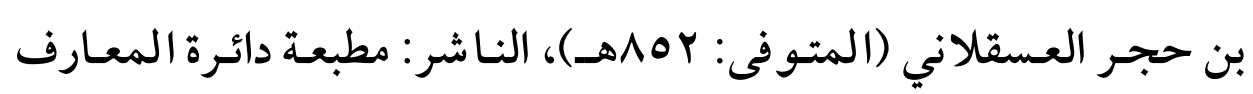

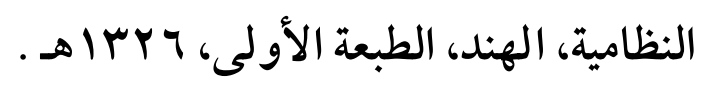

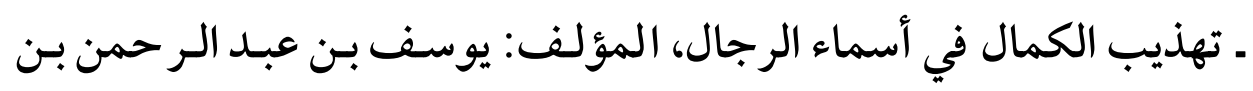

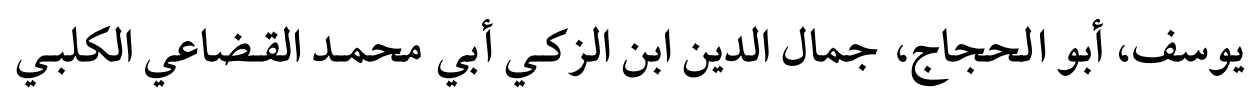

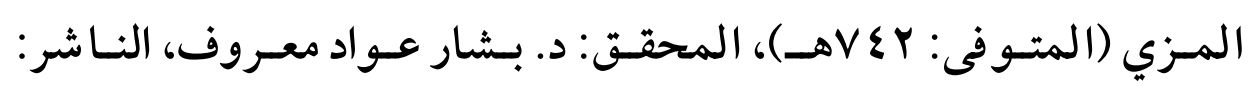

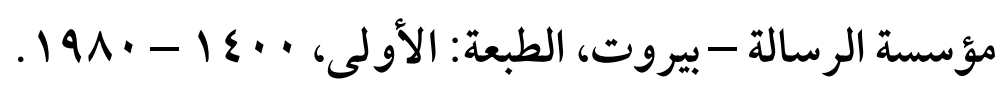

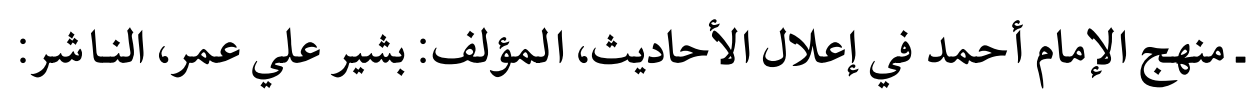

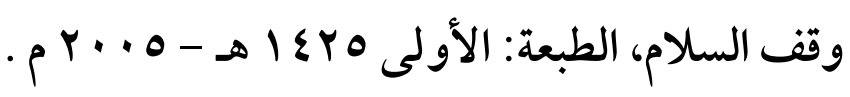


(AI)

ـ الضعفاء الكبير، المؤلف: أبو جعفر محمد بن عمرو بـن موسى بـن حمـاد

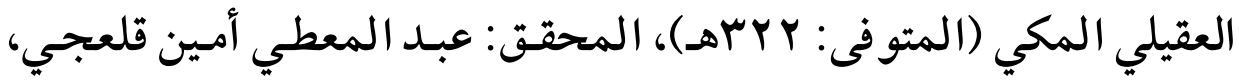

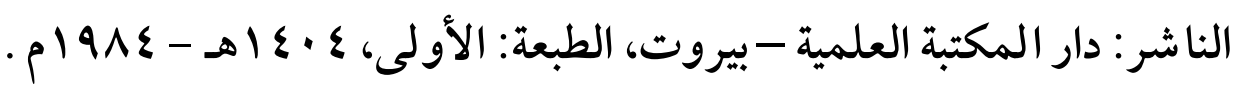
ـ إرواء الغليل في تخريج أحاديث منار السبيل، المؤلف : محمد ناصر الدين الدئ.

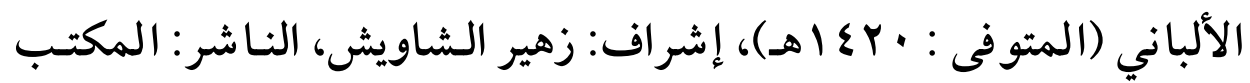

$$
\text { الإسلامي -بيروت. }
$$

ـ مجموع الفتاوى، المؤلف: تقي الدين أبو العباس أحمد بن عبد الحليم بـن

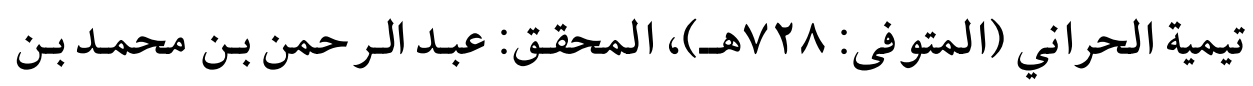

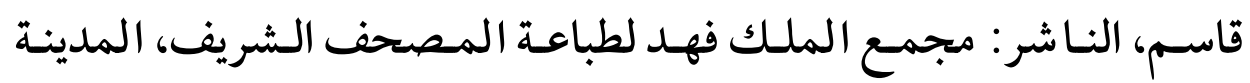

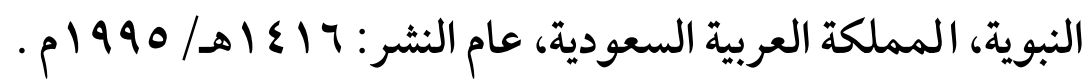

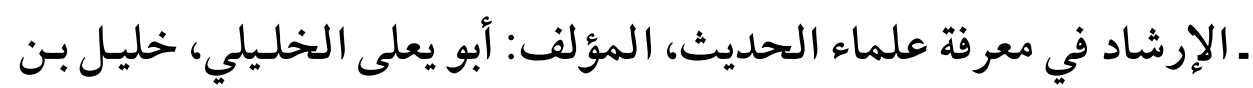

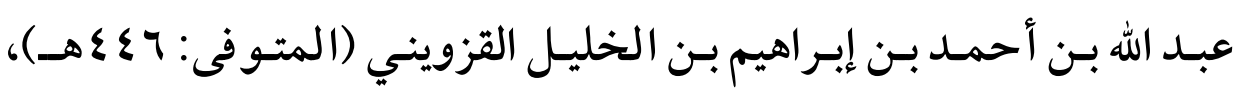

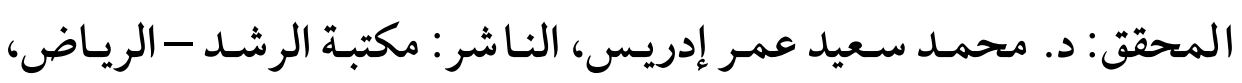

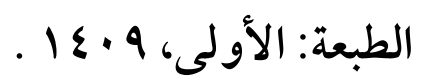

ـ . تاريخ بغداد، المؤلف: أبو بكر أحمد بن علي بن ثابت بن أحمد بن مهدي

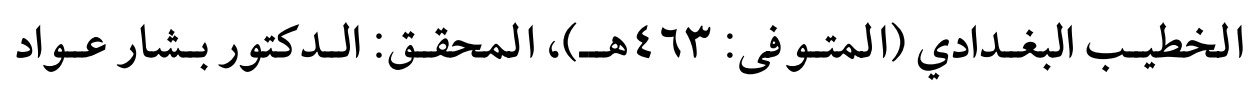

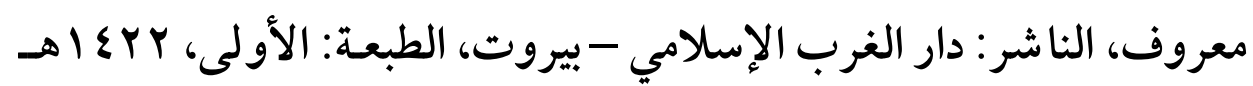
• $r \cdot r-$ ـ الثقات، المؤلف: محمد بن حبان بـن أحمـد بـن حبـان بـن معـاذ بـن مَعْبـَّة

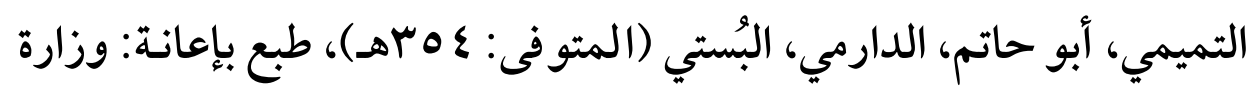


المعارف للحكومة العالية الهندية، تحت مراقبة: الدكتور محمد عبد المعيد خان مدير دائرة المعارف العثمانية، الناشر : دائرة المعـارف العثمانيـة بحيـدر

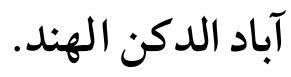
ـ توضيح الأفكار لمعاني تنقيح الأنظار، المؤلف: محمـد بـن إسـماعيل بـن

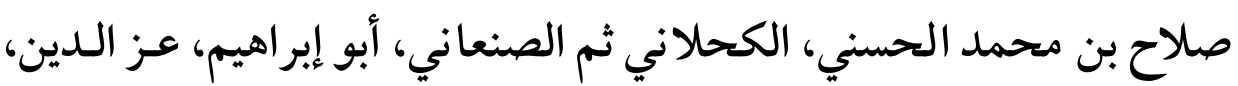

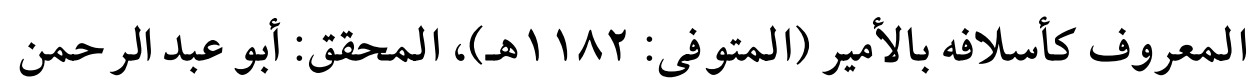
صلاح بن محمد بـن عويضة، النـاشر : دار الكتب العلمية، بيروت - لبنـان،

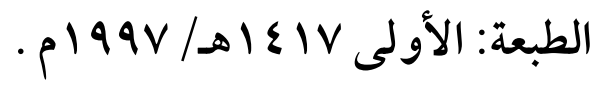
ـ لسان العرب ، المؤلف: محمد بن مكرم بن على، أبو الفضل، جمال الدين.

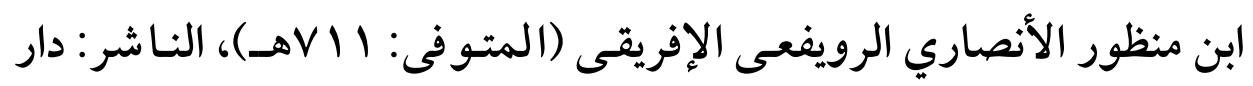

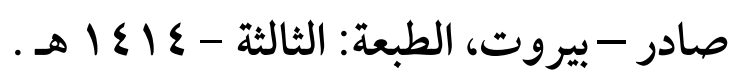

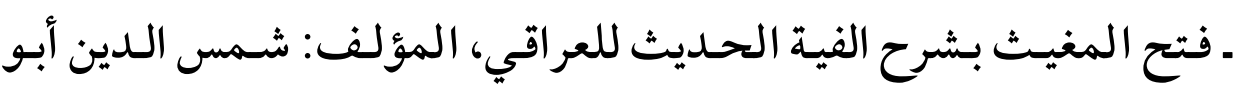

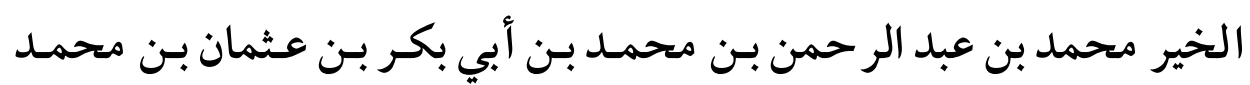

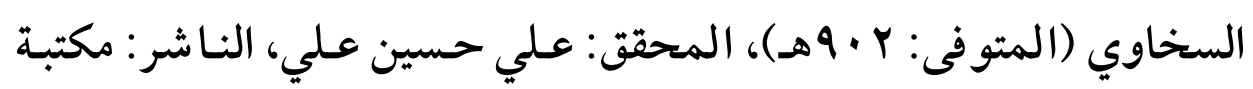

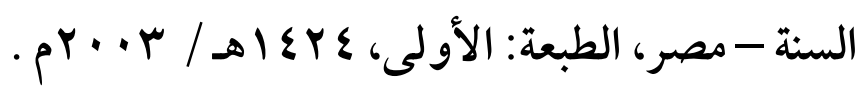

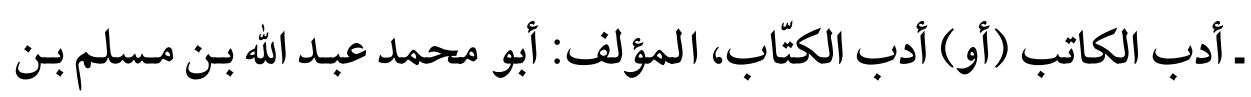

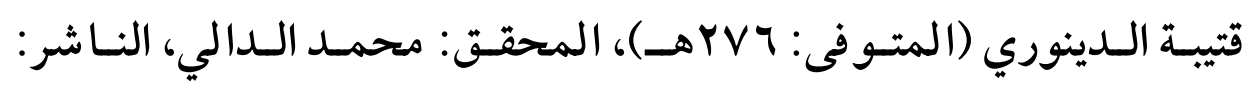

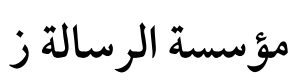
ـ الكاشف في معرفة من له رواية في الكتب الستة، المؤلف: شمس الدين أبو

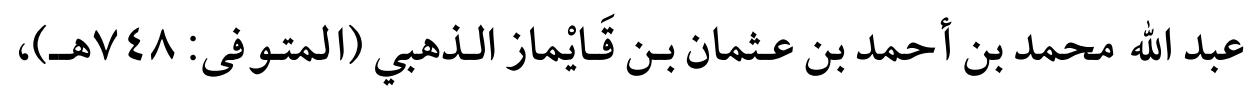




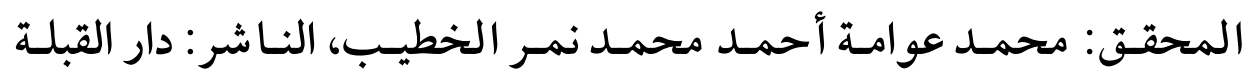

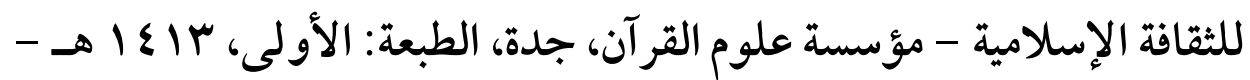
- p $199 r$ ـ. نزهة النظر في توضيح نخبة الفكر في مصطلح أهـل الأثر، المؤلف: أبـو أح الفضل أحمد بن علي بن محمد بن أحمد بـن حجر العسقلاني (المتوفى

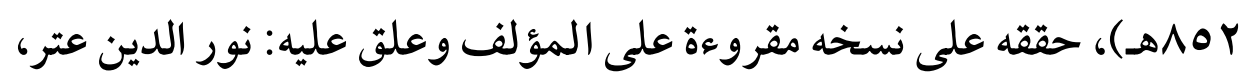

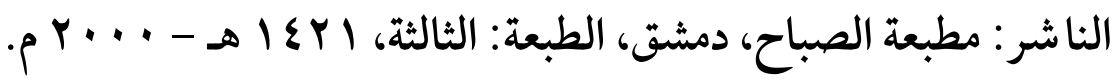

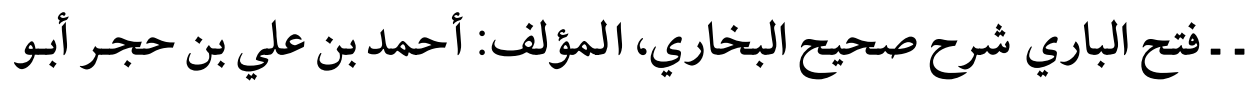
الفضل العسقلاني الشافعي، النـاشر : دار المعرفة - بيروت،

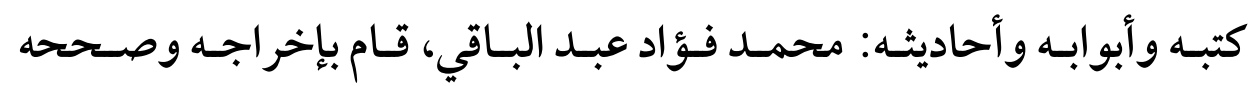
وأشرف على طبعه محب الدين الخطيب، عليه تعليقات العلامة: عبد العزيز

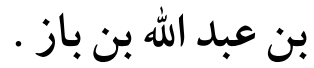
ـ العلل الواردة في الأحاديث النبوية، المؤلف: أبو الحسن علي بـن عمـر بـن

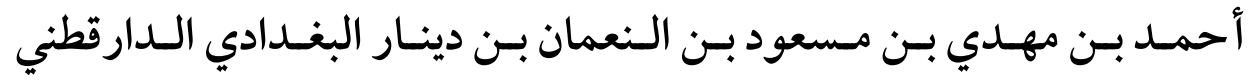

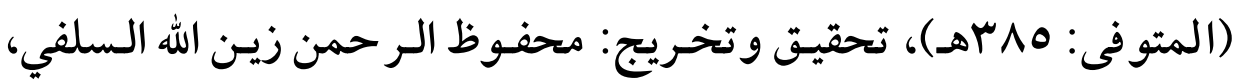

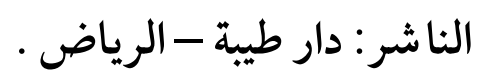

ـ معرفة الثقات من رجال أهل العلم والحديث ومن الضعفاء وذكر مـذاهبهم

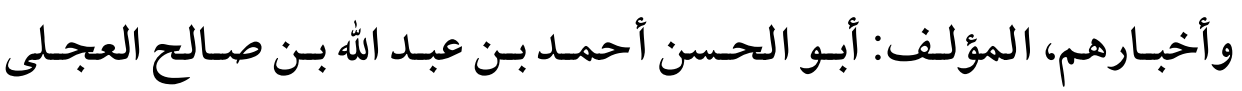

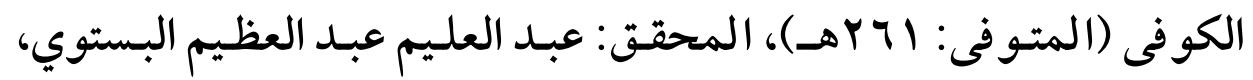




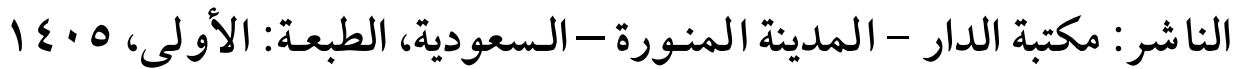
$.1910-$ ـ علم الجـرح والتعـديل (ص: ؟ه ) د/ عبــد المـنعم السيد نجـم، النـاشر: الجامعـة الإسـلامية بالمدينـة المنـورة، الطبعـة: السنة الثانيـة عشرة - العـدد

$$
\text { الأول - محرم صفر ربيع أول . . ع اهـ . }
$$

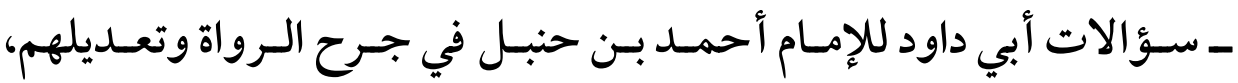
المؤلف: أبو عبد الله أحمد بن محمد بن حنبـل بـن هـلال بـن أسـد الشيباني

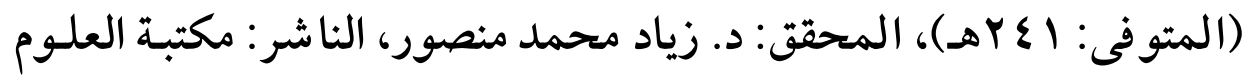

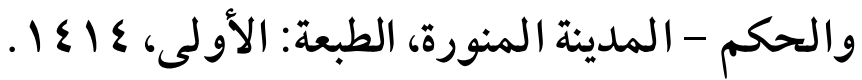

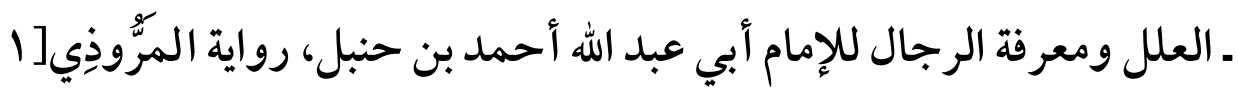

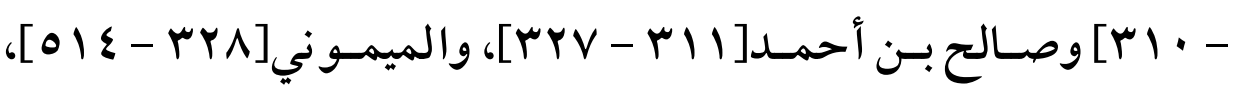

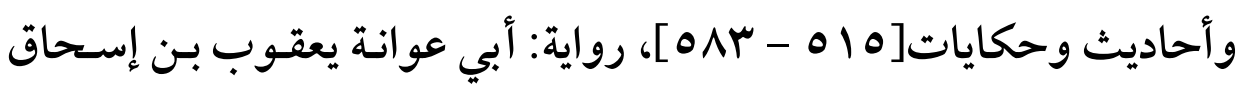

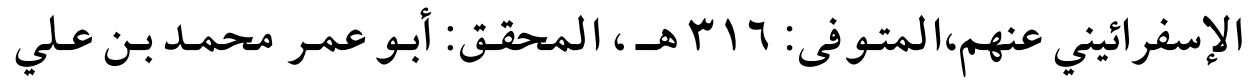

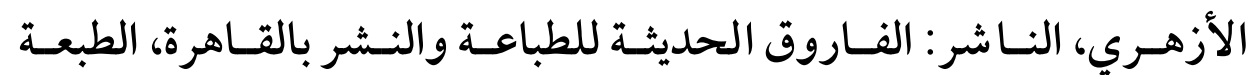

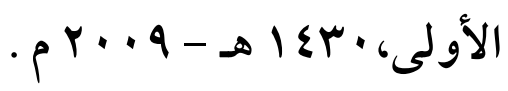
ـ سؤالات ابن الجنيد لأبي زكريا يحيى بن معين، المؤلف: أبو زكريـا يحيى الهيى

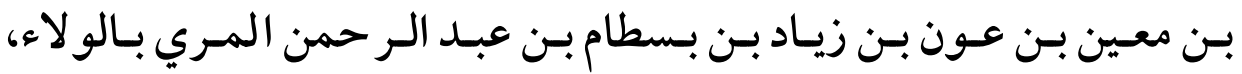

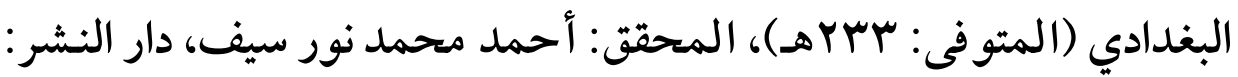

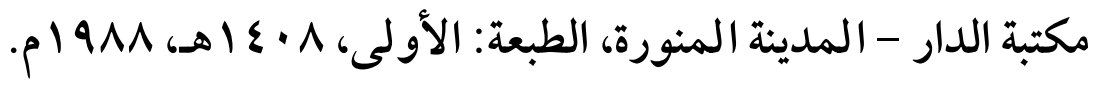


ـ العلل لابـن أبي حـاتم، المؤلف: أبـو محمـد عبـد الر حمن بـن محمـد بـن

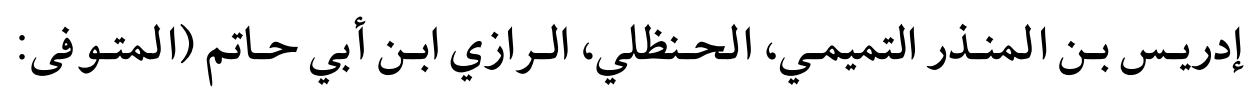

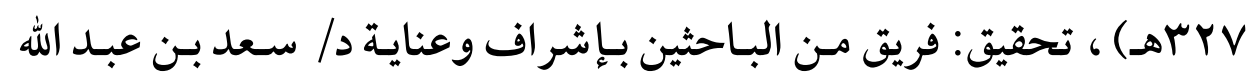

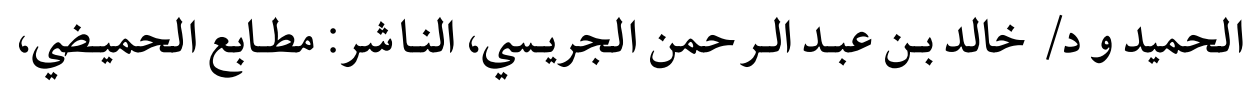

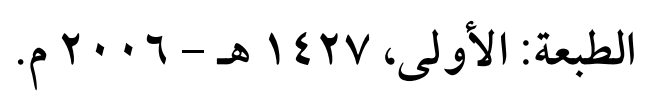

ـ ديـوان الضعفاء والمتروكين وخلـق مـن المجهـولين وثقـات فيهم لين، المؤلف: شمس الدين أبـو عبـد الله محمــد بـن أحمـد بـن عثثمان بـن قَايْماز

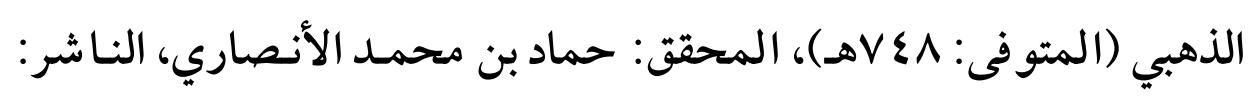

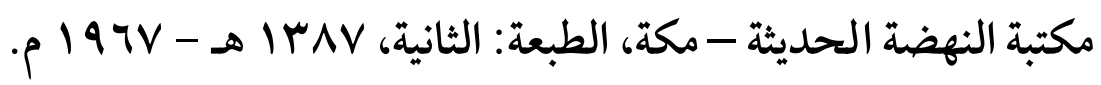

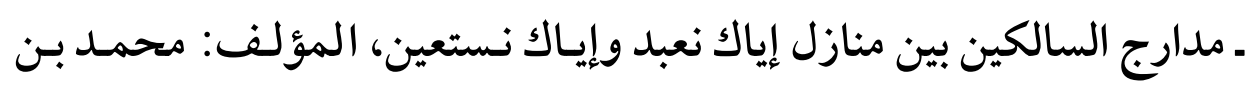
أبي بكـر بـن أيسوب بـن سـعد شـمس الـدين ابـن قـيم الجوزيـة (المتـوفى:

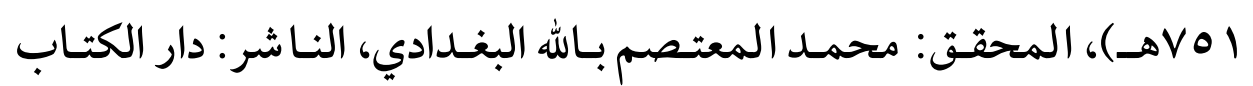

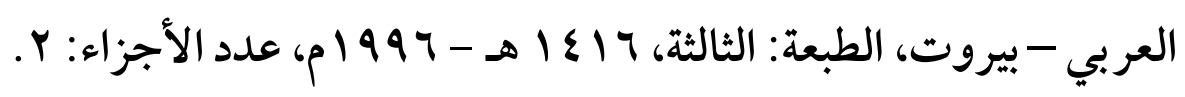
ـ فتح ذي الجلال والإكر ام بشرح بلوغ المـرام، المؤلف: محمـد بـن صـالح العثيمين تحقيـق وتعليـق: صسبحي بـن محمـــ رمضضان، أم إسراء بنـت عرفـة بيسومي،

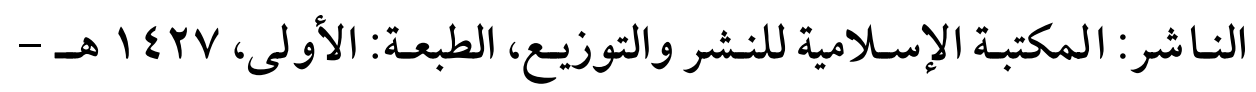

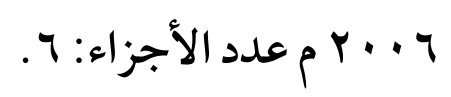

ـ الرفع والتكميل في الجرح والتعديل، المؤلف: محمد عبد الحي بن محمد

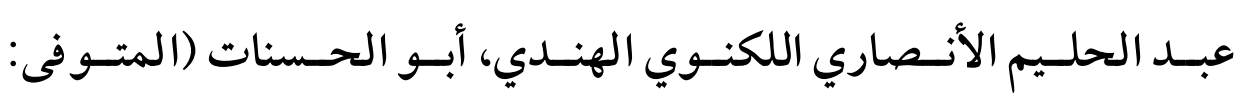


(ヘ)

دلالة المصطلحات الخاصة بين النقاد في تبريح الرواة (دراسة وتحليل)

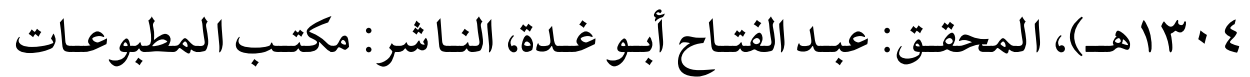

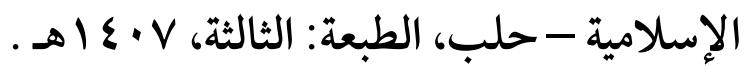

ـ تحريـر علـوم الحـديث، المؤلف: عبــ الله بـن يوسـف الجـديع، النـاشر:

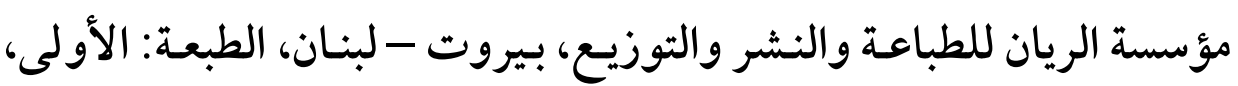

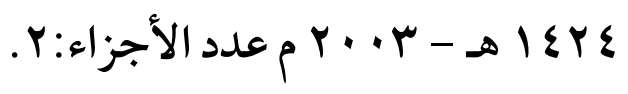


(AV)

(فهرس همتويات البمث)

\begin{tabular}{|c|c|}
\hline رقم الصفحة & الموضوع \\
\hline$r$ & ـ ملخص البحث باللغة العربية . \\
\hline$\varepsilon$ & ـ ملخص البحث باللغة الإنجليزية. \\
\hline 0 & 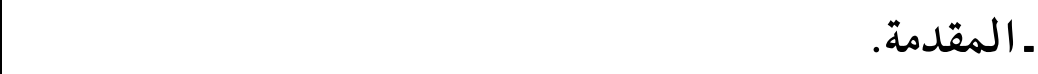 \\
\hline 7 & ـ مشكلة البحث . \\
\hline V & ـ أهداف الدراسة. \\
\hline$\wedge$ & ـ حدود الدراسة. \\
\hline$\wedge$ & ـ الدراسات السابقة. \\
\hline 1 . & ـ منهج الدراسة. \\
\hline 11 & ـ خطة البحث. \\
\hline ir & 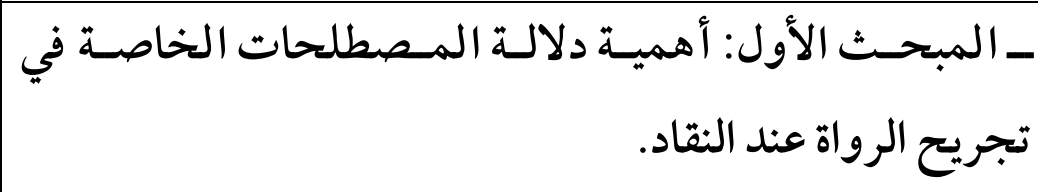 \\
\hline 10 & المطلب الأول: بيان المقصود مـن لفظة (الدلالة) واستخدام \\
\hline YT & للأئمة الثقاد. \\
\hline rq & نقد المطلب الثالث: تعريف الجرح لغة واصطلاحاً، و أهميته في \\
\hline
\end{tabular}




\begin{tabular}{|c|c|}
\hline ^) & دلالة المصطلحات الخاصة بين النقاد في تجريج الرواة (دراسة وتحليل) \\
\hline$\varepsilon r$ & ـ التي في ظاهر الثاني: دراسة لدلالة بعض التجريح. \\
\hline$\varepsilon \varepsilon$ & المطلب الأول: قو لهم في الراوي:(يسرق الحديث). \\
\hline$\varepsilon 9$ & المطلب الثاني: قولهم في الراوي:(ليس بثقة). \\
\hline $0 \varepsilon$ & المطلب الثالث: قولهم في الراوي: (شيطان). \\
\hline $0 \wedge$ & المطلب الرابع: قولهم في الراوي: (لا شيء). \\
\hline $7 r$ & المطلب الخامس: قو لهم في الراوي: (ليس بالمشهور). \\
\hline 79 & المطلب السادس: قولهم في الراوي: (كذاب). \\
\hline$\vee \varepsilon$ & 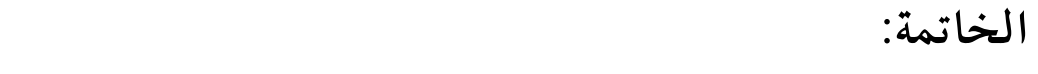 \\
\hline VY & فهرس المصادر والمراجع. \\
\hline$\Lambda \vee$ & فهرس محتويات البحث. \\
\hline
\end{tabular}

